\title{
Could London Dispersion Force Control Regioselective (2+2) Cyclodimerizations of Benzynes? YES: Application to the Synthesis of Helical Biphenylenes
}

Takashi Ikawa,* Yuta Yamamoto, Akito Heguri, Yutaka Fukumoto, Tomonari Murakami, Akira Takagi, Yuto Masuda, Kenzo Yahata, Hiroshi Aoyama, Yasuteru Shigeta, Hiroaki Tokiwa,* Shuji Akai*

Laboratory of Organic Chemistry, Gifu Pharmaceutical University, 1-25-4 Daigakunishi, Gifu, Gifu 501-1196, Japan.

Department of Chemistry, Rikkyo University, Nishi-Ikebukuro, Toshima, Tokyo 1718501, Japan

Graduate School of Pharmaceutical Sciences, Osaka University, 1-6 Yamadaoka, Suita, Osaka 565-0871, Japan.

Center for Computational Sciences, University of Tsukuba, 1-1-1 Tennodai, Tsukuba, Ibaraki 305-8577, Japan

E-mail: ikawa-ta@gifu-pu.ac.jp

\section{Table of contents}

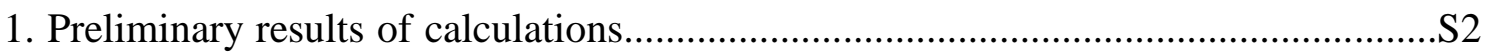

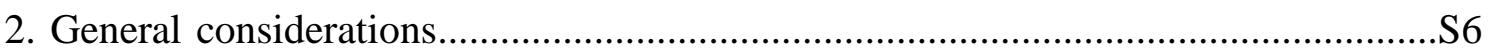

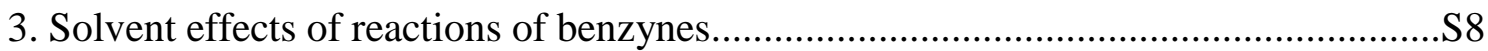

4. [4+2] cycloaddition reactions on 3 -substituted benzynes.......................................S9

5. Experimental procedure, spectroscopic and numerical data

5-1. General Procedure for $(2+2)$ cycloadditions in Tables 1 and 2....................S10

5-2. Spectroscopic and numerical data of cycloaddition products 7 and 10..............S11

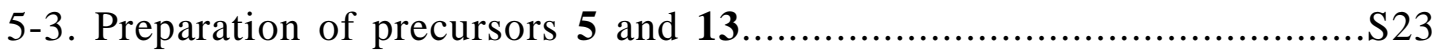

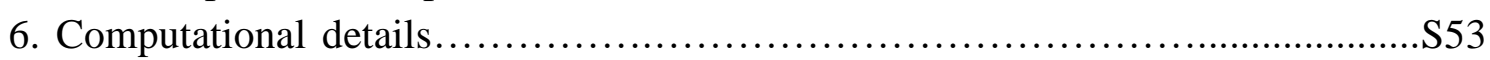

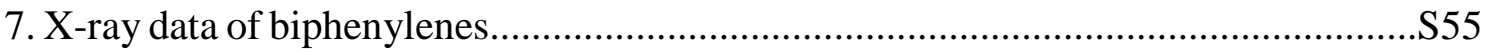

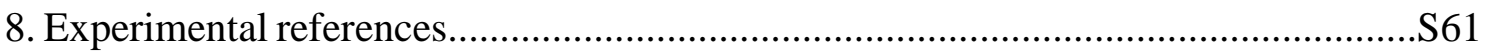

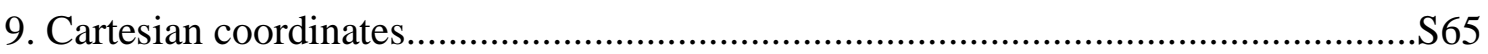

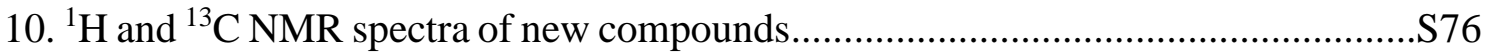




\section{Preliminary results of calculations:}

There are two possible mechanisms of our $(2+2)$ cyclodimerizations of fused benzynes $\mathbf{9}$; a concerted mechanism and a stepwise mechanism. However, the concerted mechanism can be eliminated from consideration because the concerted thermal $(2+2)$ cycloaddition is forbidden by the Woodward-Hoffmann rules. ${ }^{[1]}$ Therefore, the discussion in the following study is focused on the stepwise mechanism.

The first interaction between the two fused tetracyclic benzyne molecules 9a will be via either one-to-one (Type 1) or two-to-one orbital interactions (Type 2) (Figure S1).

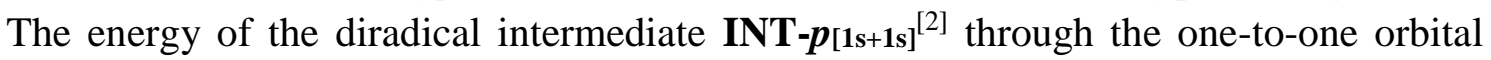
interaction is much lower $(52.6 \mathrm{kcal} / \mathrm{mol})$ than that of the carbene intermediate INT-

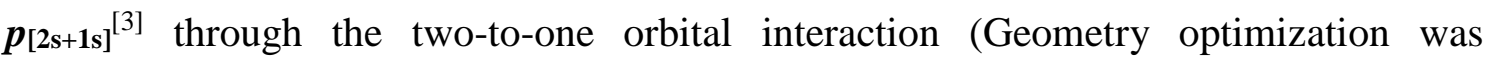
performed at the CASSCF $(4,4) / 3-21 \mathrm{G}$ level, and the energy calculation of the optimized structure was carried out at the CASPT2(4,4)/cc-pVDZ level, using Gaussian 09). ${ }^{[4][5]}$ This result indicates that the first step of the $(2+2)$ cycloaddition reactions of tetracyclic benzynes 9 should be the one-to-one orbital interaction (Type 1).

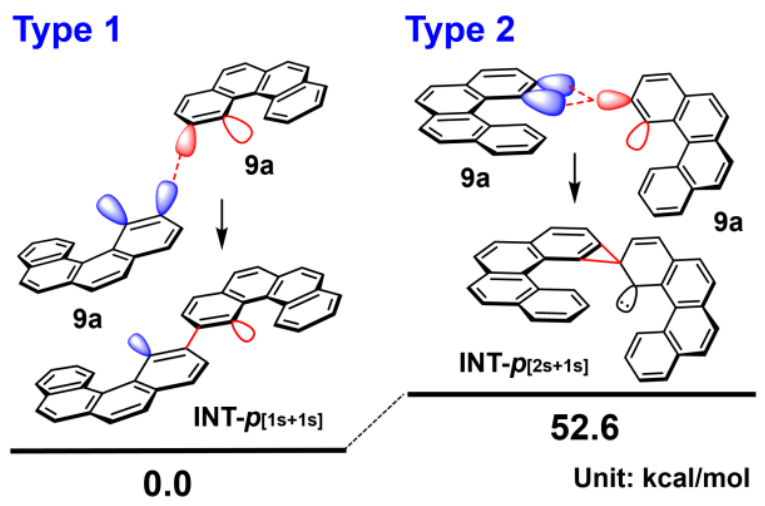

Figure S1. First interaction steps between two benzo[c]phenanthrynes 9a in two types of reaction mechanisms for $(2+2)$ cycloadditions (CASPT2(4,4)/cc-pVDZ//CASSCF(4,4)/3-21G).

The reaction coordinate of the first step is shown in Figure S2 (The reaction pathway analysis was performed the broken-symmetry singlet diradical calculations at the UB97D/6-31G(d) level, and the energy calculations of the optimized structures were carried out at the CASPT2(4,4)/cc-pVDZ level using Gaussian 09). ${ }^{[4][5]}$ The barrier along the reaction path does not seem to be present. The two fused tetracyclic benzyne molecules 9a would come closer to generate the above-mentioned diradical intermediate INT-p $[1 \mathbf{s}+1 \mathbf{s}]$. The energy stabilization in the first step is quite small $(\approx 0.1 \mathrm{kcal} / \mathrm{mol})$. These observations suggest that the first step of our $(2+2)$ cyclodimerizations of benzynes 9 generating INT- $\boldsymbol{p}_{[\mathbf{1 s}+\mathbf{1 s}]}$ is reversible. 


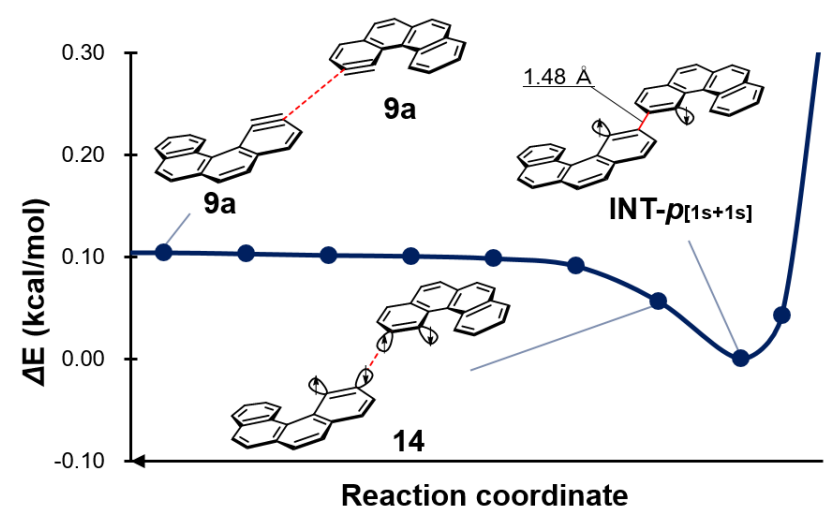

Figure S2. Energy diagram of the first step of plausible reaction mechanism for $(2+2)$ cycloadditions of benzo[c]phenanthryne 9a (CASPT2(4,4)/cc-pVDZ//UB97D/6-31G(d)).

The second step should be the rotation ${ }^{[6]}$ around on the newly formed $\sigma$-bond of

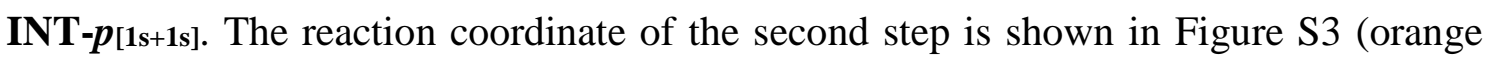
dots and a line for the reaction of tetracyclic benzynes, benzo[c]phenanthrynes 9a) (The reaction pathway analyses and the energy calculations of optimized structures were performed the broken-symmetry singlet diradical calculations at the UB97D/6-31G(d) level using Gaussian 09). ${ }^{[5]}$ The energy was increased from INT- $\boldsymbol{p}_{[\mathbf{1 s}+\mathbf{1 s}]}$ to the transition state-like structure TS- $\boldsymbol{p}_{[\mathbf{1 s}+\mathbf{1 s}]}$ ' and rapidly decreased to provide the helical biphenylene, proximal-10a. Notably, all energies of the intermediates for the reactions of fused bicyclic- and tricyclic benzynes $\mathbf{S 1}$ and $\mathbf{S 2}$ (gray and green dots, and lines) are higher than those of the tetracyclic one 9a. This second rotation step should be the rate-determining step (RDS) because the first step seems to be barrierless and reversible (see, Figure S1 and S2). Therefore, discussions surrounding the real transition states TS- $\boldsymbol{p}_{[\mathbf{1 s}+1 \mathrm{~s}]}$ of the second step should be important (Figure S4).

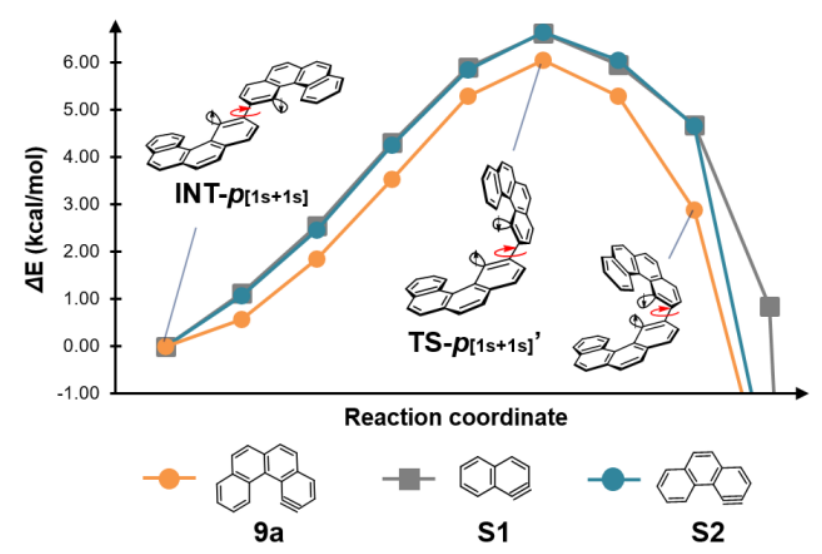

Figure S3. Energy diagram of the second step of plausible two-step reaction mechanism for the $(2+2)$ cycloadditions of naphthalyne S1, phenanthryne S2, and benzo[c]phenanthryne 9a (UB97D/6$31 \mathrm{G}(\mathrm{d}) / / \mathrm{UB} 97 \mathrm{D} / 6-31 \mathrm{G}(\mathrm{d}))$. 
The comparison among the activation energies for the $(2+2)$ cycloadditions of bicyclic-, tricyclic-, and tetracyclic benzynes (S1, S2, and 9a) is shown in Figure S4 (The transition state search was performed the broken-symmetry singlet diradical calculations at the UB97D/6-31G(d) level, and the energy calculations of the transition state structures were carried out at the CASPT2(4,4)/aug-cc-pVDZ level using Gaussian 09). ${ }^{[4][5]} \mathrm{We}$ found that the activation energy for the $(2+2)$ cycloaddition of tetracyclic benzyne $9 \mathbf{a}$ is the lowest at $4.6 \mathrm{kcal} / \mathrm{mol}$. Therefore, it might be reasonable for it to give the best yield $(87 \%)$ of the cyclodimerization product, proximal-10a, from tetracyclic benzyne $9 \mathbf{a}$, and $0 \%$ yields of proximal-11a and -12a from $\mathbf{S 1}$ and $\mathbf{S 2}$.
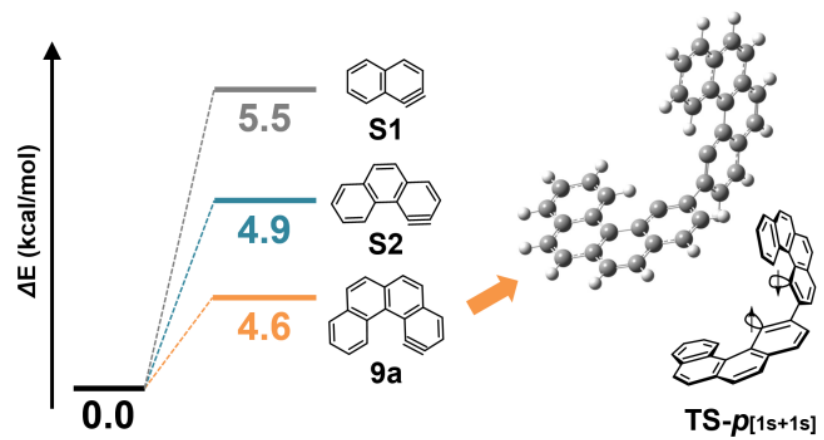

Figure S4. Activation energy of the second step of the plausible mechanism for $(2+2)$ cycloadditions of naphthalyne S1, phenanthryne S2, and benzo[c]phenanthryne 9a (CASPT2(4,4)/aug-cc-pVDZ//UB97D/6$31 G(d))$.

The energy decomposition analyses $(\mathrm{EDA})^{[7][8]}$ for the second step reaction coordinates of the $(2+2)$ cyclodimerization of bicyclic-, tricyclic-, and tetracyclic fused benzynes (S1, S2, and 9a) have been carried out using GAMESS ${ }^{[9]}$, and the dispersion interactions are plotted on Figure S5 (The reaction pathway analyses were performed the broken-symmetry singlet diradical calculations at the UB97D/6-31G(d) level, and the energy calculations of the optimized structures were carried out at the MP2/cc-pVDZ level using Gaussian 09). ${ }^{[4][5]}$ The energy stabilizations by dispersion interactions on the whole reaction pathway of tetracyclic benzynes $9 \mathbf{a}$ (orange dots and a line) are the largest among these three reactions from S1, S2, and 9a. We believe that the dispersion interaction reduced the energy of TS- $p_{[1 \mathbf{s}+1 \mathbf{s}]}$, and the reaction of the tetracyclic benzyne 9a is much faster and cleaner than those of others. 


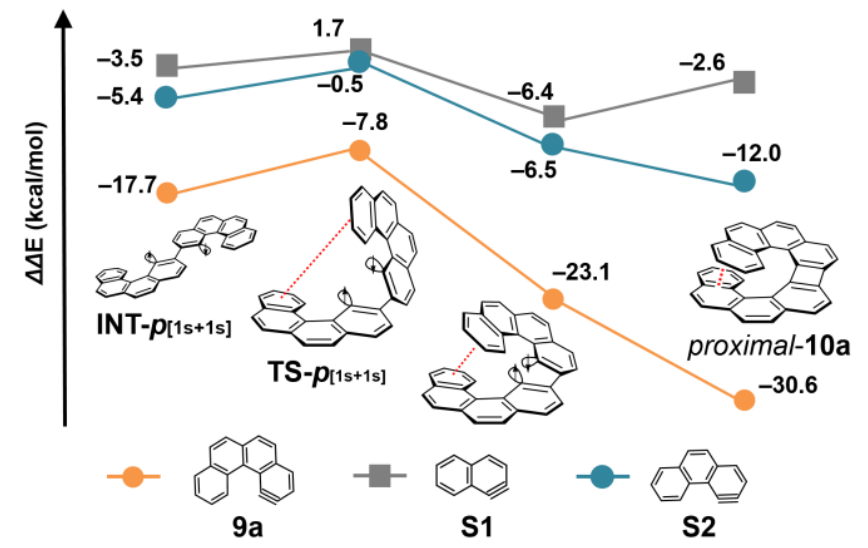

Figure S5. Interaction energy between two fragments of intermediates of the second step in the plausible mechanism for the $(2+2)$ cycloadditions of naphthalyne S1, phenanthryne S2, and benzo[c]phenanthryne 9a (MP2/cc-pVDZ//UB97D/6-31G(d)).

A plausible whole energy diagram for our $(2+2)$ cyclodimerization of the tetracyclic benzyne 9a with that which produces the by-product is illustrated in Figure S6. The intermediate INT $\boldsymbol{d} \boldsymbol{d}[\mathbf{1 s}+\mathbf{1 s}]$ of the first step through one-to-one orbital interaction producing distal-10a could not be found; however, the activation energy $\Delta \mathrm{E}_{2}$ producing distal-10a should be more important and would be much higher than $\Delta \mathrm{E}_{3}$, which provides proximal10a. We believe that this is the reason for the exclusive formation of proximal-10a. Additionally, the clean reaction with 9a can be explained by that the activation energyproducing by-product $\Delta \mathrm{E}_{4}$, which may be higher than $\Delta \mathrm{E}_{3}$ (The by-product forming pathway from 9a may not be just one pathway). The activation energy-producing proximal-11a from $\mathbf{S 1}$ and proximal-12a from $\mathbf{S 2}$ may be much higher than those producing the by-products.

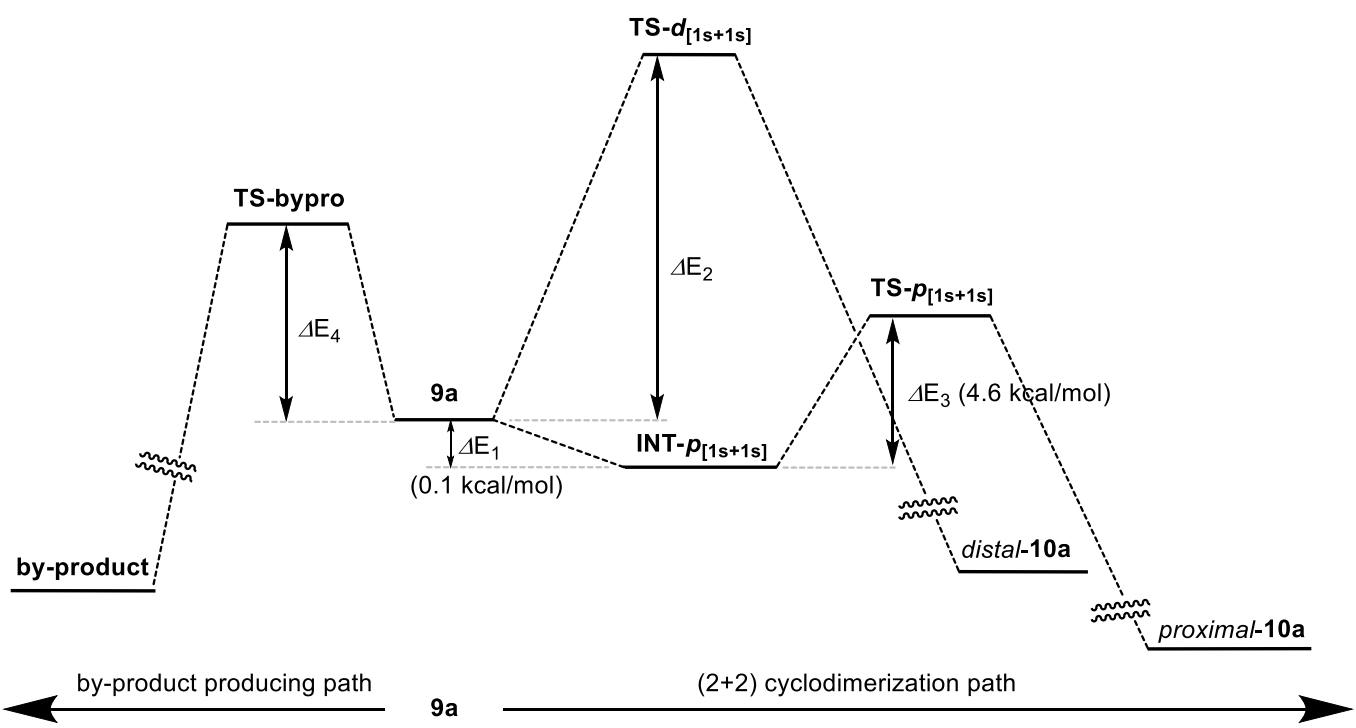

Figure S6. Energy profiles for all $(2+2)$ cycloadditions of benzo[c]phenanthryne 9a. 


\section{General considerations:}

Reagents: All reactions were carried out under a nitrogen atmosphere. A round-bottomed flasks with a three-way stopcock or a Schlenk flask containing a magnetic stirrer were used as reactors and heated by an oil bath (Riko or Techno Sigma). Anhydrous THF, $\mathrm{Et}_{2} \mathrm{O}$, $\mathrm{CH}_{2} \mathrm{Cl}_{2}$, DMF and $\mathrm{MeCN}$ were purchased from Kanto Chemical or FUJIFILM Wako Pure Chemical, and purified with a Glass Contour solvent dispensing system (Nikko Hansen) using two packed columns of activated molecular sieves. 2,6-Diiodo-4methylphenol, ${ }^{[10]}$ and 2-allylfuran ${ }^{[11]}$ were prepared according to the literature. $1.1 \mathrm{M}$ $\mathrm{MeLi}$ in $\mathrm{Et}_{2} \mathrm{O}$ was purchased from Kanto Chemical. All other reagents were purchased from FUJIFILM Wako Pure Chemical, Tokyo Chemical Industry, Sigma-Aldrich, nacalai tesque, Kishida Chemical, Chem Impex International, Oakwood Products and CombiBlocks and used without further purification. Flash chromatography ${ }^{[12]}$ was performed with silica gel $60 \mathrm{~N}$, spherical neutral $(40-50 \mu \mathrm{m})$, purchased from Kanto Chemical. Gel permeation chromatography (GPC) was performed with JAIGEL-2HR, JAIGEL-1H-40, and JAIGEL-2H-40 purchased from Japan Analytical Industry. All reactions were monitored by thin-layer chromatography (TLC) on glass-backed silica gel $60 \mathrm{~F}^{254}, 0.2$ $\mathrm{mm}$ plates (Merck), and compounds were visualized under UV light (254 nm).

Analytical methods: Melting points were recorded on a Yanagimoto melting point apparatus and are uncorrected. IR spectra were obtained on a SHIMADZU IRAffinity1S. ${ }^{1} \mathrm{H}$ NMR and ${ }^{13} \mathrm{C}$ NMR spectra were recorded on a JEOL JMN-ECA-500 $\left({ }^{1} \mathrm{H}: 500\right.$ $\left.\mathrm{MHz},{ }^{13} \mathrm{C}: 125 \mathrm{MHz},{ }^{19} \mathrm{~F}: 470 \mathrm{MHz}\right)$, a JEOL JMN-ECS-400 $\left({ }^{1} \mathrm{H}: 400 \mathrm{MHz},{ }^{13} \mathrm{C}: 100\right.$ $\left.\mathrm{MHz},{ }^{19} \mathrm{~F}: 376 \mathrm{MHz}\right)$, a JEOL AL-300 ( $\left.{ }^{1} \mathrm{H}: 300 \mathrm{MHz}\right)$. Instrument with chemical shifts reported in ppm relative to the residual deuterated solvent. LC/MS spectra were taken on Agilent InfinityLab LC/MSD. GC spectra were taken on SHIMADZU GC-2010. The mass spectra were recorded on a JEOL JMS-S3000 (MALDI), a JEOL JMS-T100TD (APCI), and a JEOL JMS-700 (EI, CI, FAB) spectrometers. "Yield" refers to the isolated yields of compounds showing at most only trace peaks in the ${ }^{1} \mathrm{H}$ NMR spectra that are not attributable to the assigned structure. ${ }^{1} \mathrm{H}$ NMR and melting points (where applicable) of all known compounds were taken. All new products were further characterized by high resolution mass spectrum (HRMS). The regiochemistries of cycloaddition products 
(proximal-7d and distal-7d) were determined by comparing each NOESY NMR spectra. The regiochemistries of cycloaddition products (proximal-7e, proximal-7f, distal-7f, proximal-7h, proximal-7i, proximal-10a, proximal-10b, proximal-10d, and proximal10e) were confirmed by a single-crystal $X$-ray structure analysis. The regiochemistries of several cycloaddition products (proximal-7c, distal-7c, proximal-7g, distal-7g, proximal10c, and proximal-10f) were estimated from reported data and the data of our confirmed compounds. 


\section{Solvent effects on $(2+2)$ cyclodimerizations of benzynes:}

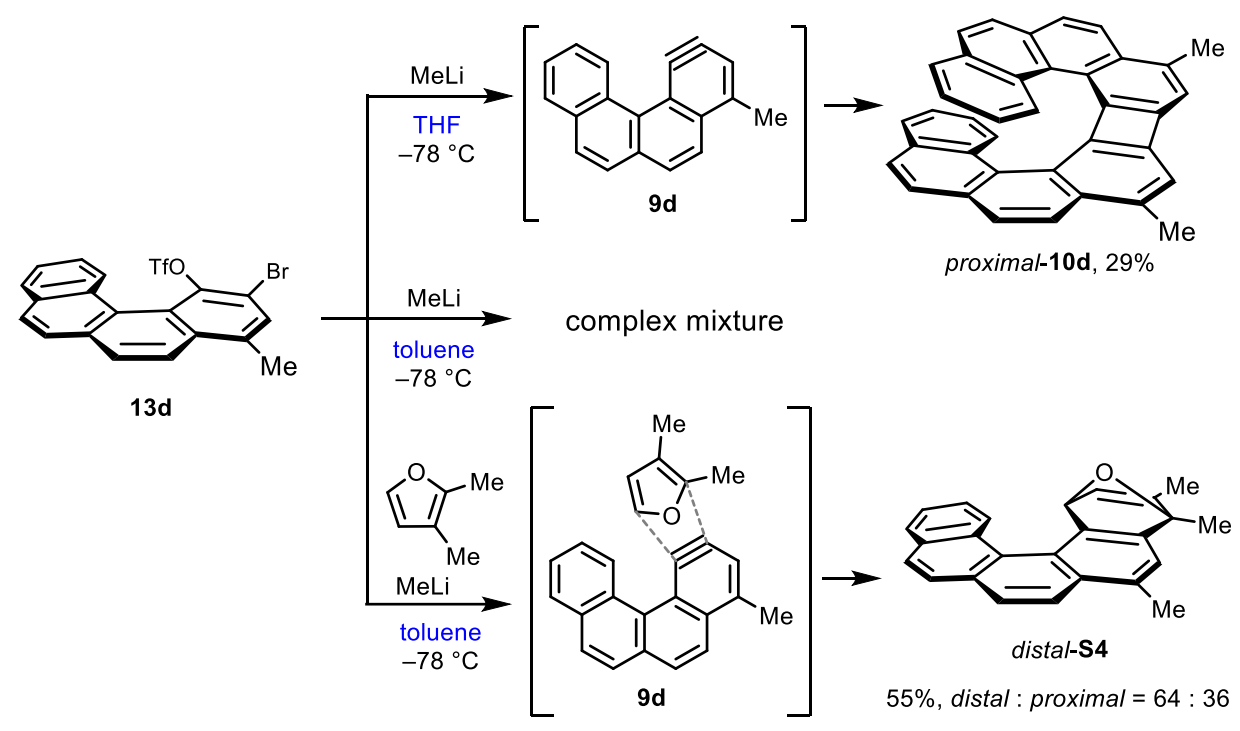

Scheme S1. Solvent effects on $(2+2)$ cyclodimerization of fused benzyne 9d.

Table S1. Optimization of (2+2) cyclodimerization of 3-adamantylbenzyne $\mathbf{6 i}$.

\begin{tabular}{|c|c|c|c|c|c|}
\hline & & $\begin{array}{c}\underset{\text { reagent }}{\longrightarrow} \\
\text { solvent }(0.1 \mathrm{M}) \\
-78{ }^{\circ} \mathrm{C} \\
15 \mathrm{~min}\end{array}$ & $\stackrel{\text { Ad }}{d}$ & Ad & side product $\mathbf{8 b}$ \\
\hline entry & $x$ & solvent & reagent & yield of $7 \mathbf{i}$ & side product $\mathbf{8 b}$ \\
\hline 1 & । & THF & MeLi (1.5 equiv) & $74 \%$ & $n d^{a}$ \\
\hline 2 & । & toluene & MeLi (2.0 equiv) & $78 \%$ & $n d^{a}$ \\
\hline 3 & 1 & $\mathrm{Et}_{2} \mathrm{O}$ & MeLi (2.0 equiv) & $43 \%^{a}$ & $n d^{a}$ \\
\hline 4 & 1 & THF & $n$-BuLi (1.5 equiv) & $46 \%^{a}$ & $\mathrm{nd}^{\mathrm{a}}$ \\
\hline 5 & 1 & THF & $\mathrm{Me}_{3} \mathrm{SiCH}_{2} \mathrm{MgCl}$ (2.0 equiv) & $\mathrm{nd}^{\mathrm{a}}$ & $\mathrm{nd}^{\mathrm{a}}$ \\
\hline 6 & I & THF & $i-\mathrm{PrMgCl} \cdot \mathrm{LiCl}$ (2.0 equiv) & $n d^{a}$ & $\mathrm{nd}^{\mathrm{a}}$ \\
\hline 7 & $\mathrm{H}$ & THF & LTMP ( 1.5 equiv) & $\mathrm{nd}^{\mathrm{a}}$ & $n d^{a}$ \\
\hline 8 & $\mathrm{Br}$ & THF & MeLi (2.0 equiv) & $54 \%^{a}$ & side product $\mathbf{S 3}(25 \%)^{\mathrm{a}}$ \\
\hline 9 & $\mathrm{Br}$ & toluene & MeLi (2.0 equiv) & $11 \%^{a}$ & side product $\mathbf{S 3}(56 \%)^{a}$ \\
\hline
\end{tabular}

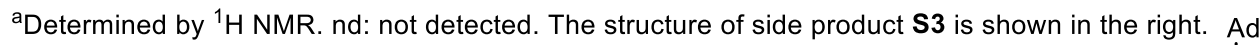<smiles>Cc1cc(C)c(Br)c(C)c1</smiles> 


\section{4. [4+2] cycloaddition reactions of sterically hindered 3-substituted benzynes:}

Our unpublished result

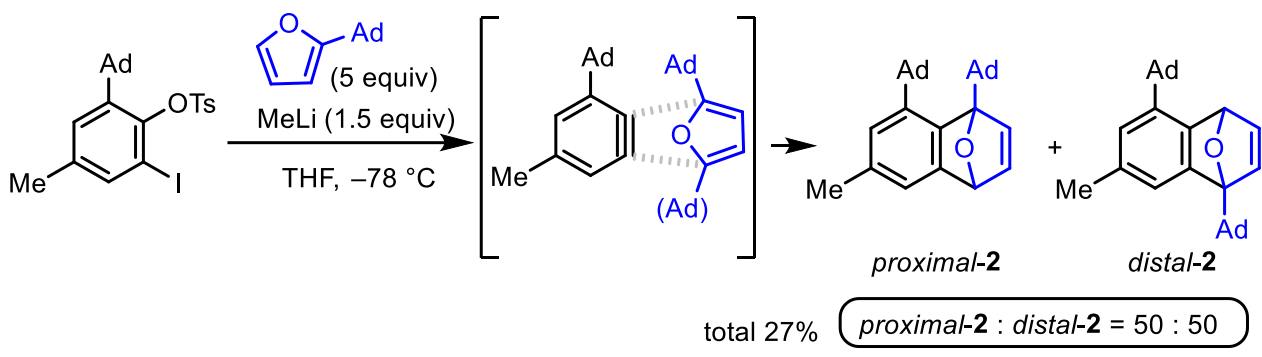

Data reported by Yamaguchi et al. ${ }^{[13]}$

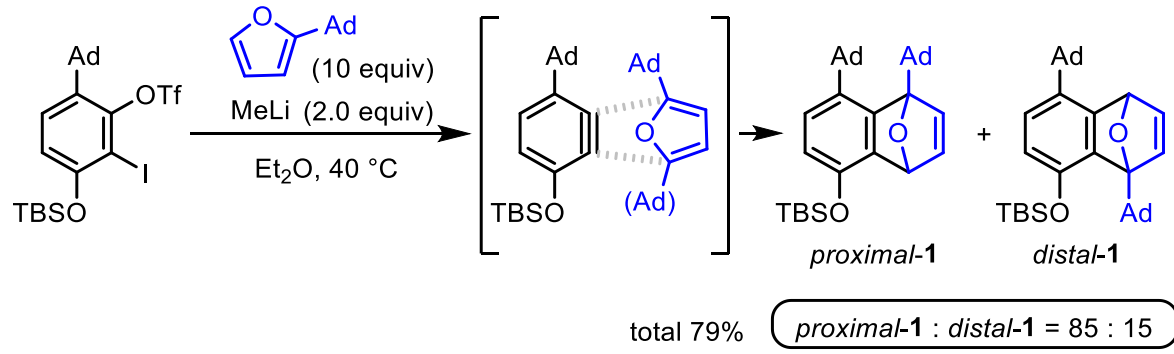

Data reported by our group ${ }^{[14]}$

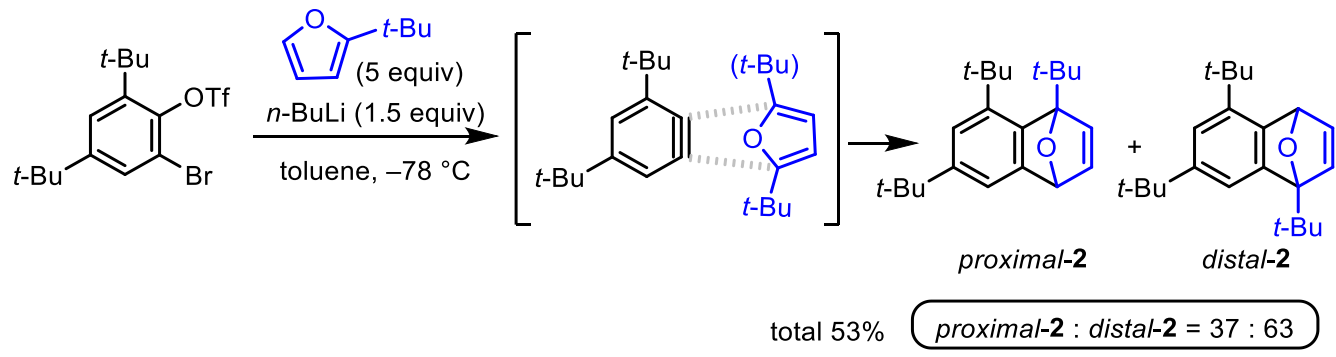

Data reported by Franck et al. ${ }^{[15]}$

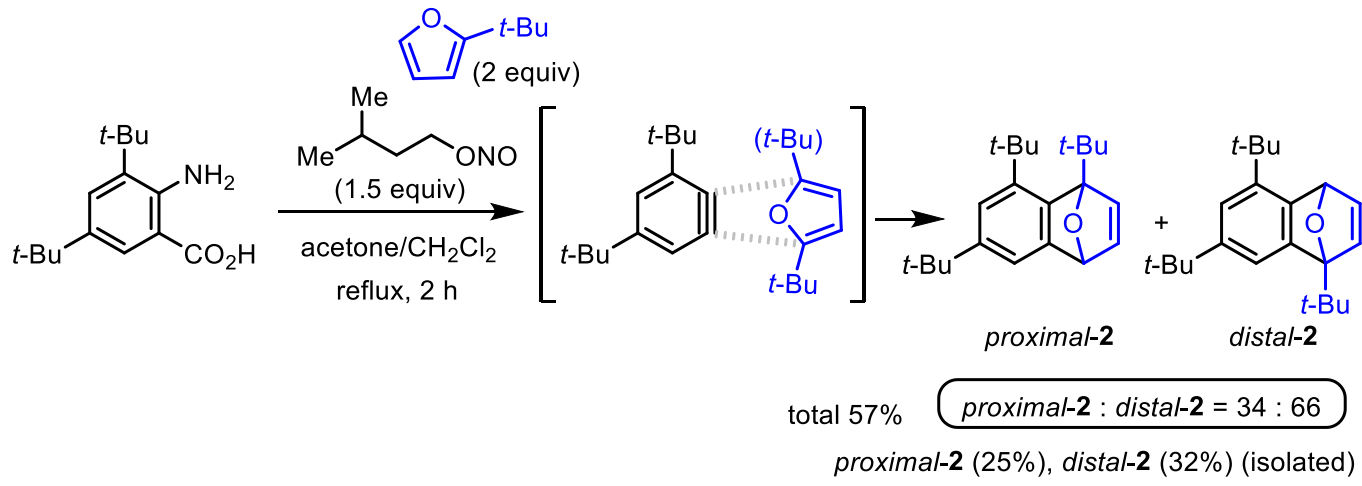




\section{Experimental procedure, spectroscopic and numerical data:}

\section{5-1. General Procedure for $(2+2)$ cycloadditions in Tables 1 and 2}
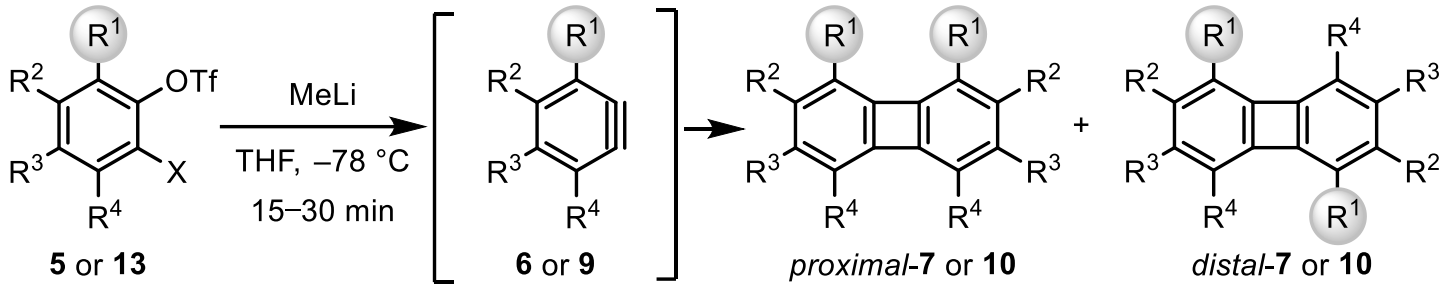

Scheme S2. $(2+2)$ cyclodimerizations of benzynes 6 or 9 generated from precursors 5 or 13 (Table 1, 2, and Scheme 3).

General Procedure I: An oven-dried flask with a magnetic stir bar equipped with an inlet adapter with three-way stopcock was evacuated and back-filled with Ar. A benzyne precursor 5 or 13 (1.0 equiv) was charged in the flask and evacuated and back-filled with Ar. Anhydrous THF $(0.10 \mathrm{M})$ was added to the flask via a syringe and cooled to $-78{ }^{\circ} \mathrm{C}$. 1.1 M MeLi solution in $\mathrm{Et}_{2} \mathrm{O}$ (1.5 equiv) was added to the mixture at $-78^{\circ} \mathrm{C}$ via a syringe and the mixture was stirred for $15-30 \mathrm{~min}$. A saturated solution of $\mathrm{NH}_{4} \mathrm{Cl}$ was added to the mixture, and the mixture was extracted thrice with $\mathrm{Et}_{2} \mathrm{O}$, EtOAc or hexane. The combined organic phase was washed with brine. The organic phase was dried over $\mathrm{Na}_{2} \mathrm{SO}_{4}$ or $\mathrm{MgSO}_{4}$, and the solvent was removed under reduced pressure. The residue was subjected to ${ }^{1} \mathrm{H}$ NMR analysis for calculating the ratio and total NMR yield of the two regioisomers (proximal-7 or $\mathbf{1 0}$ and distal-7 or 10) using 1,1,2,2,-tetrachloroethane as an internal standard. The crude product was purified by flash column chromatography on silica gel (a mixture of hexane and EtOAc or $\mathrm{CH}_{2} \mathrm{Cl}_{2}$ with $2 \% \mathrm{Et}_{3} \mathrm{~N}$ ) or by trituration with $\mathrm{Et}_{2} \mathrm{O}$ to afford distal-7 or $\mathbf{1 0}$ and proximal-7 or $\mathbf{1 0}$ or by recrystallization from $\mathrm{CHCl}_{3} / \mathrm{MeOH}$. 
5-2. Spectroscopic and numerical data of cycloaddition products 7 and 10

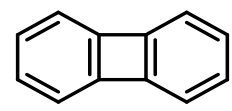

$7 \mathbf{a}$

Biphenylene (7a) ${ }^{[16]}$ (Table 1, entry 1): Following the General Procedure I, 2iodophenyl trifluoromethanesulfonate (5a) $(85 \mathrm{mg}, 0.24 \mathrm{mmol})$, and $1.1 \mathrm{M} \mathrm{MeLi}$ in $\mathrm{Et}_{2} \mathrm{O}$ $(0.33 \mathrm{~mL}, 0.36 \mathrm{mmol})$ in THF $(0.10 \mathrm{M}, 2.4 \mathrm{~mL})$ was stirred for $30 \mathrm{~min}$ at $-78^{\circ} \mathrm{C}$. The yield of the titled compound 7a (20\%) was calculated by ${ }^{1} \mathrm{H}$ NMR analysis. ${ }^{1} \mathrm{H}$ NMR (500 $\left.\mathrm{MHz}_{\mathrm{CDCl}}\right) \delta: 6.62-6.64(4 \mathrm{H}, \mathrm{m}), 6.73-6.74(4 \mathrm{H}, \mathrm{m}) .{ }^{13} \mathrm{C} \mathrm{NMR}\left(125 \mathrm{MHz}, \mathrm{CDCl}_{3}\right)$ $\delta: 117.5,128.4,151.5$<smiles>COc1cccc2c1-c1c(OC)cccc1-2</smiles>

proximal-7b<smiles>COc1cccc2c1-c1cccc(OC)c1-2</smiles>

distal-7b

1,8-Dimethoxybiphenylene (proximal-7b) ${ }^{[17]}$ and 1,5-dimethoxybiphenylene (distal7b) ${ }^{[18]}$ (Table 1, entry 2): Following the General Procedure I, 2-iodo-6-methoxyphenyl trifluoromethanesulfonate $(\mathbf{5 b})(0.24 \mathrm{~g}, 0.64 \mathrm{mmol})$, and $1.1 \mathrm{M} \mathrm{MeLi}$ in $\mathrm{Et}_{2} \mathrm{O}(0.87 \mathrm{~mL}$, $0.96 \mathrm{mmol})$ in THF $(0.10 \mathrm{M}, 6.4 \mathrm{~mL})$ was stirred for $30 \mathrm{~min}$ at $-78{ }^{\circ} \mathrm{C}$. The reaction mixture was extracted with EtOAc. However, the titled compounds, proximal-7b and distal-7b could not be observed.<smiles>Cc1cc(C)c2c(c1)-c1cc(C)cc(C)c1-2</smiles>

proximal-7c<smiles>Cc1cc(C)c2c(c1)-c1c(C)cc(C)cc1-2</smiles>

distal-7c

1,3,6,8-Tetramethylbiphenylene (proximal-7c) and 1,3,5,7-tetramethylbiphenylene (distal-7c) (Table 1, entry 3): Following the General Procedure I, 2-iodo-4,6dimethylphenyl trifluoromethanesulfonate (5c) $(0.56 \mathrm{~g}, 1.5 \mathrm{mmol})$, and $1.1 \mathrm{M} \mathrm{MeLi}$ in $\mathrm{Et}_{2} \mathrm{O}(2.1 \mathrm{~mL}, 2.2 \mathrm{mmol})$ in THF $(0.10 \mathrm{M}, 15 \mathrm{~mL})$ was stirred for $15 \mathrm{~min}$ at $-78{ }^{\circ} \mathrm{C}$. The 
reaction mixture was extracted with $\mathrm{Et}_{2} \mathrm{O}$ (proximal-7c/distal-7c $=1.1: 1$, determined by ${ }^{1} \mathrm{H}$ NMR) and purified by column chromatography on silica gel (hexane/EtOAc $=10: 1$ ) and $\mathrm{GPC}\left(\mathrm{CHCl}_{3}\right)$ to obtain a mixture of the titled compounds, proximal-7c and distal-7c $(54 \mathrm{mg}, 36 \%$, proximal-7c/distal-7c $=1.2: 1)$ as a colorless oil. ${ }^{1} \mathrm{H}$ NMR $(500 \mathrm{MHz}$, $\left.\mathrm{CDCl}_{3}\right) \delta: 2.06(30 / 11 \mathrm{H}, \mathrm{s}), 2.13(36 / 11 \mathrm{H}, \mathrm{s}), 2.136(30 / 11 \mathrm{H}, \mathrm{s}), 2.142(36 / 11 \mathrm{H}, \mathrm{s})$, $6.31(10 / 11 \mathrm{H}, \mathrm{s}), 6.31(10 / 11 \mathrm{H}, \mathrm{s}), 6.32(12 / 11 \mathrm{H}, \mathrm{s}), 6.34(12 / 11 \mathrm{H}, \mathrm{s}) .{ }^{13} \mathrm{C} \mathrm{NMR}(100$ $\left.\mathrm{MHz}, \mathrm{CDCl}_{3}\right) \delta: 17.2,18.1,21.8,21.9,116.0,116.3,126.0,127.1,129.0,129.9,137.4$, 138.2, 145.0, 146.5, 150.1, 151.0. IR (neat): $2918 \mathrm{~cm}^{-1}$. HRMS (MALDI) Calcd for $\mathrm{C}_{16} \mathrm{H}_{16}[\mathrm{M}]^{+}:$208.1247. Found: 208.1247.

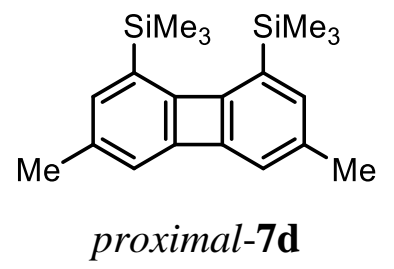

1,8-Bis(trimethylsilyl)-3,6-dimehylbiphenylene (proximal-7d) (Table 1, entry 4): Following the General Procedure I, 2-iodo-4-methyl-6-(trimethylsilyl)phenyl trifluoromethanesulfonate $(\mathbf{5 d})(0.12 \mathrm{~g}, 0.64 \mathrm{mmol})$, and $1.5 \mathrm{M} \mathrm{MeLi}$ in $\mathrm{Et}_{2} \mathrm{O}(0.27 \mathrm{~mL}$, $0.40 \mathrm{mmol})$ in THF $(0.24 \mathrm{M}, 2.7 \mathrm{~mL})$ was stirred for $15 \mathrm{~min}$ at $-78{ }^{\circ} \mathrm{C}$. The reaction mixture was extracted with EtOAc ( $85 \%$ yield, proximal-7d/distal-7d $=1.1: 1$, determined by ${ }^{1} \mathrm{H}$ NMR) and purified by column chromatography on silica gel (hexane) to obtain the titled compound, proximal-7d (23 mg, 38\% isolated yield) as a pale yellow solid. The regiochemistry was confirmed by NOESY NMR analysis. Mp: 160-161. ${ }^{1} \mathrm{H}$ NMR (500 $\left.\mathrm{MHz}, \mathrm{CDCl}_{3}\right) \delta: 0.31(18 \mathrm{H}, \mathrm{s}), 2.14(6 \mathrm{H}, \mathrm{s}), 6.45$ (2 H, brs), 6.66 (2 H, brs). ${ }^{13} \mathrm{C} \mathrm{NMR}$ $\left(100 \mathrm{MHz}, \mathrm{CDCl}_{3}\right) \delta: 0.8,21.8,117.5,131.2,133.5,136.2,151.0,157.7$. IR (neat): 2950 $\mathrm{cm}^{-1}$. HRMS (MALDI) Calcd for $\mathrm{C}_{20} \mathrm{H}_{28} \mathrm{Si}_{2}[\mathrm{M}]^{+}:$324.1724. Found: 324.1722. 


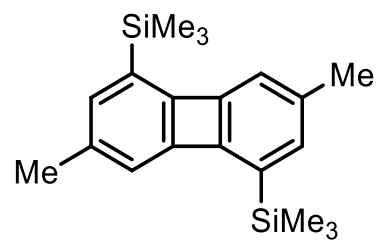

distal-7d

1,5-Bis(trimethylsilyl)-3,7-dimethylbiphenylene (distal-7d) (Table 1, entry 4) was obtained by purified by column chromatography on silica gel (hexane) to obtain the titled compound, distal-7d (23 mg, 38\% isolated yield) as a colorless solid. The regiochemistry was confirmed by NOESY NMR analysis. Mp: 162-163. ${ }^{1} \mathrm{H} \mathrm{NMR}\left(500 \mathrm{MHz}, \mathrm{CDCl}_{3}\right) \delta$ : $0.26(18 \mathrm{H}, \mathrm{s}), 2.17(6 \mathrm{H}, \mathrm{s}), 6.47(2 \mathrm{H}, \mathrm{d}, J=1.0 \mathrm{~Hz}), 6.59(2 \mathrm{H}, \mathrm{d}, J=1.0 \mathrm{~Hz}) .{ }^{13} \mathrm{C} \mathrm{NMR}$ $\left(100 \mathrm{MHz}, \mathrm{CDCl}_{3}\right) \delta:-1.5,22.2,119.3,130.0,131.2,136.9,152.3,154.2$. IR (neat): 2955 $\mathrm{cm}^{-1}$. HRMS (MALDI) Calcd for $\mathrm{C}_{20} \mathrm{H}_{28} \mathrm{Si}_{2}[\mathrm{M}]^{+}:$324.1724. Found: 324.1732.

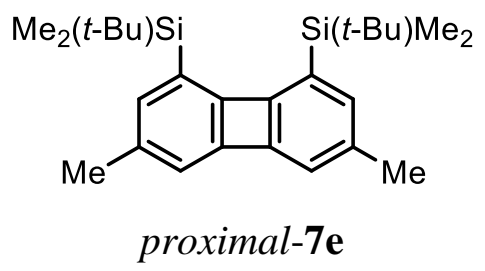

1,8-Bis(tert-butyldimethylsilyl)-3,6-dimethylbiphenylene (proximal-7e) (Table 1, entry 5): Following the General Procedure I, 2-iodo-6-(tert-butyldimethylsilyl)-4methylphenyl trifluoromethanesulfonate (5e) $(0.17 \mathrm{~g}, 0.36 \mathrm{mmol})$, and $1.1 \mathrm{M} \mathrm{MeLi} \mathrm{in}$ $\mathrm{Et}_{2} \mathrm{O}(0.49 \mathrm{~mL}, 0.54 \mathrm{mmol})$ in $\mathrm{THF}(0.10 \mathrm{M}, 3.6 \mathrm{~mL})$ was stirred for $30 \mathrm{~min}$ at $-78{ }^{\circ} \mathrm{C}$. The reaction mixture was extracted with EtOAc (83\% yield, proximal-7e/distal-7e = 7.0:1, determined by ${ }^{1} \mathrm{H}$ NMR) and purified by column chromatography on silica gel (hexane) to obtain the titled compound, proximal-7e (52 mg, 70\% isolated yield) as a pale yellow solid. The obtained solid was recrystallized from $\mathrm{CHCl}_{3} / \mathrm{MeOH}$ and the regiochemistry was determined by a single-crystal X-ray structure analysis. Mp: $143-144{ }^{\circ} \mathrm{C}$. ${ }^{1} \mathrm{H}$ NMR (400 MHz, $\left.\mathrm{CDCl}_{3}\right) \delta$ : $0.32(12 \mathrm{H}, \mathrm{s}), 0.98(18 \mathrm{H}, \mathrm{s}), 2.15$ (6 H, s), 6.45 (2 H, brs), 6.79 (2 $\mathrm{H}$, brs $) .{ }^{13} \mathrm{C} \mathrm{NMR}\left(100 \mathrm{MHz}, \mathrm{CDCl}_{3}\right) \delta:-2.78,18.2,21.8,27.7,117.2,130.2,134.2,135.3$, 151.1, 159.5. IR (neat): $2929 \mathrm{~cm}^{-1}$. HRMS (MALDI) Calcd for $\mathrm{C}_{26} \mathrm{H}_{40} \mathrm{Si}_{2}[\mathrm{M}]^{+}: 408.2663$. Found: 408.2666. 


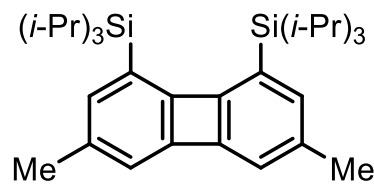

proximal-7f

1,8-Bis(triisopropylsilyl)-3,6-dimethylbiphenylene (proximal-7f) (Table 1, entry 6):

From triflate (5f): Following the General Procedure I, 2-iodo-4-methyl-6(triisopropylsilyl)phenyl trifluoromethanesulfonate $(\mathbf{5 f})(0.58 \mathrm{~g}, 1.1 \mathrm{mmol})$, and $1.1 \mathrm{M}$ MeLi in $\mathrm{Et}_{2} \mathrm{O}(1.6 \mathrm{~mL}, 1.7 \mathrm{mmol})$ in THF $(0.10 \mathrm{M}, 11 \mathrm{~mL})$ was stirred for $15 \mathrm{~min}$ at $78^{\circ} \mathrm{C}$. The reaction mixture was extracted with $\mathrm{Et}_{2} \mathrm{O}(56 \%$ yield, proximal $-\mathbf{7 f} /$ distal $-7 \mathbf{f}=$ 9.5:1, determined by ${ }^{1} \mathrm{H}$ NMR:).

From tosylate (5f'): Following the General Procedure I, 2-iodo-4-methyl-6(triisopropylsilyl)phenyl 4-methylbenzenesulfonate (5f') $(0.11 \mathrm{~g}, 0.20 \mathrm{mmol})$, and $1.1 \mathrm{M}$ MeLi in $\mathrm{Et}_{2} \mathrm{O}(0.36 \mathrm{~mL}, 0.40 \mathrm{mmol})$ in $\mathrm{THF}(0.10 \mathrm{M}, 2.0 \mathrm{~mL})$ was stirred for $15 \mathrm{~min}$ at $78{ }^{\circ} \mathrm{C}$. The reaction mixture was extracted with $\mathrm{Et}_{2} \mathrm{O}$ and purified by column chromatography on silica gel (hexane/ $\mathrm{CH}_{2} \mathrm{Cl}_{2}=9: 1$ then $3: 2$ ) to obtain the titled compound, proximal-7f (11 mg, 15\% isolated yield) as a colorless solid. The obtained solid was recrystallized from $\mathrm{CHCl}_{3} / \mathrm{MeOH}$ and the regiochemistry was determined by a single-crystal X-ray structure analysis. Mp: $176-177{ }^{\circ} \mathrm{C} .{ }^{1} \mathrm{H} \mathrm{NMR}\left(400 \mathrm{MHz}, \mathrm{CDCl}_{3}\right) \delta$ : $1.15(36 \mathrm{H}, \mathrm{d}, J=7.5 \mathrm{~Hz}), 1.38(6 \mathrm{H}$, sept, $J=7.5 \mathrm{~Hz}), 2.13(6 \mathrm{H}, \mathrm{s}), 6.42(2 \mathrm{H}, \mathrm{d}, J=1.0$ $\mathrm{Hz}), 6.65$ (2 H, brs). ${ }^{13} \mathrm{C} \mathrm{NMR}\left(100 \mathrm{MHz}, \mathrm{CDCl}_{3}\right) \delta: 13.4,19.8,21.9,116.5,128.9,135.0$, 135.4, 151.2, 160.1. IR (neat): $2945 \mathrm{~cm}^{-1}$. HRMS (MALDI) Calcd for $\mathrm{C}_{32} \mathrm{H}_{52} \mathrm{Si}_{2}[\mathrm{M}]^{+}$: 492.3602. Found: 492.3603.

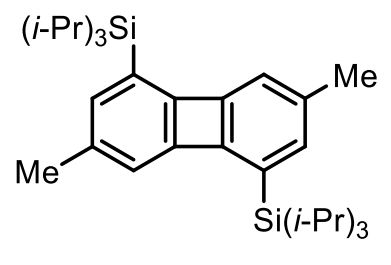

distal-7f

1,5-Bis(triisopropylsilyl)-3,7-dimethylbiphenylene (distal-7f) (Table 1, entry 6) was obtained by above-mentioned procedure by column chromatography on silica gel (hexane/ $\mathrm{CH}_{2} \mathrm{Cl}_{2}=9: 1$ then 3:2) to obtain the titled compound, distal-7f (1.6 mg, $1 \%$ isolated yield) as a colorless solid. The obtained solid was recrystallized from 
$\mathrm{CHCl}_{3} / \mathrm{MeOH}$ and the regiochemistry was determined by a single-crystal X-ray structure analysis. Mp: $225-226{ }^{\circ} \mathrm{C} .{ }^{1} \mathrm{H}$ NMR $\left(500 \mathrm{MHz}, \mathrm{CDCl}_{3}\right) \delta: 1.10(36 \mathrm{H}, \mathrm{d}, J=7.5 \mathrm{~Hz})$, 1.38 (6 H, sept, $J=7.5 \mathrm{~Hz}), 2.15$ (6 H, s), 6.40 (2 H, brs), 6.57 (2 H, brs). ${ }^{13} \mathrm{C}$ NMR (125 $\mathrm{MHz}, \mathrm{CDCl}_{3}$ ) $\delta: 11.3,18.6,22.5,119.1,125.0,133.3,136.1,153.2,156.0$. IR (neat): 2944 $\mathrm{cm}^{-1}$. HRMS (MALDI) Calcd for $\mathrm{C}_{32} \mathrm{H}_{52} \mathrm{Si}_{2}[\mathrm{M}]^{+}$: 492.3602. Found: 492.3605 .<smiles>CCCc1cc2c(c(C(C)C)c1)-c1c-2cc(C(C)C)cc1C(C)C</smiles>

proximal-7g<smiles>CCCc1cc2c(c(C(C)C)c1)-c1c-2cc(C(C)C)cc1C(C)C</smiles>

distal-7g

\section{1,3,6,8-Tetraisopropylbiphenylene}

tetraisopropylbiphenylene (distal-7g) (Table 1, entry 7): Following the General Procedure I, 2-iodo-4,6-diisopropylsilylphenyl trifluoromethanesulfonate (5g) (0.53 g, $1.2 \mathrm{mmol})$, and $1.1 \mathrm{M} \mathrm{MeLi} \mathrm{in} \mathrm{Et}_{2} \mathrm{O}(1.7 \mathrm{~mL}, 1.8 \mathrm{mmol})$ in THF (1.0 M, $\left.12 \mathrm{~mL}\right)$ was stirred for $15 \mathrm{~min}$ at $-78{ }^{\circ} \mathrm{C}$. The reaction mixture was extracted with $\mathrm{Et}_{2} \mathrm{O}(51 \%$ yield, proximal-7g/distal-7g $=7.7: 1$, determined by ${ }^{1} \mathrm{H}$ NMR) and purified by column chromatography on silica gel (hexane/EtOAc $=33: 1)$ and $\mathrm{GPC}\left(\mathrm{CHCl}_{3}\right)$ to obtain $70 \mathrm{mg}$ of a mostly pure mixture of proximal-7g and distal-7g. The mixture was purified again by column chromatography on silica gel (hexane and hexane/EtOAc $=50: 1,2 \% \mathrm{Et}_{3} \mathrm{~N}$ ) to obtain a mixture of the titled compounds, proximal-7g and distal-7g (Fr.1: 17 mg, Fr.2: $24 \mathrm{mg}$ and Fr.3: $2 \mathrm{mg}$, total $36 \%$ yield) as a pale yellow oil. The spectra data of Fr.2 (proximal-7g/distal-7g $=15: 1)$ are shown below. ${ }^{1} \mathrm{H}$ NMR $\left(500 \mathrm{MHz}, \mathrm{CDCl}_{3}\right) \delta: 1.18$ $(180 / 16 \mathrm{H}, \mathrm{d}, J=7.0 \mathrm{~Hz}), 1.19(12 / 16 \mathrm{H}, \mathrm{d}, J=7.0 \mathrm{~Hz}), 1.22(180 / 16 \mathrm{H}, \mathrm{d}, J=7.0 \mathrm{~Hz})$, $1.24(12 / 16 \mathrm{H}, \mathrm{d}, J=7.0 \mathrm{~Hz}), 2.64-2.72$ (34/16 H, m), 2.91 (30/16 H, sept), 6.39 (2/16 H, brs), 6.39 (2/16 H, brs), 6.42 (30/16 H, d, $J=1.0 \mathrm{~Hz}), 6.48$ (30/16 H, brs). ${ }^{13} \mathrm{C}$ NMR (125 $\left.\mathrm{MHz}, \mathrm{CDCl}_{3}\right) \delta: 22.70,23.0,23.7,30.6,31.7,34.7,34.8,113.5,114.6,122.3,124.2,137.3$, 138.7, 143.7, 145.8, 149.2, 149.5, 149.9, 151.5. IR (neat): $2961 \mathrm{~cm}^{-1}$. HRMS (MALDI) Calcd for $\mathrm{C}_{24} \mathrm{H}_{32}[\mathrm{M}]^{+}: 320.2499$. Found: 320.2494 . 


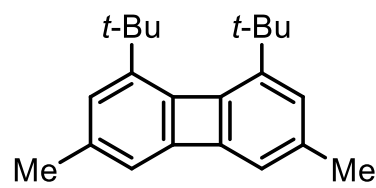

proximal-7h

1,8-Di-tert-butyl-3,6-dimethylbiphenylene (proximal-7h) (Table 1, entry 8): Following the General Procedure I, 2-iodophenyl-6-tert-butyl-4-methylphenyl trifluoromethanesulfonate $(\mathbf{5 h})(2.4 \mathrm{~g}, 5.6 \mathrm{mmol})$, and 1.1 M MeLi in $\mathrm{Et}_{2} \mathrm{O}(7.6 \mathrm{~mL}, 8.4$ $\mathrm{mmol})$ in THF $(0.10 \mathrm{M}, 56 \mathrm{~mL})$ was stirred for $15 \mathrm{~min}$ at $-78^{\circ} \mathrm{C}$. The reaction mixture was extracted with $\mathrm{Et}_{2} \mathrm{O}$ (proximal-7h/distal-7h $=16: 1$, determined by ${ }^{1} \mathrm{H} \mathrm{NMR}$ ) and purified by column chromatography on silica gel (hexane/EtOAc $=50: 1$ with $1 \% \mathrm{Et}_{3} \mathrm{~N}$ ) to obtain the titled compound, proximal-7h $(0.43 \mathrm{~g}, 52 \%$ isolated yield $)$ as a yellow solid. The obtained solid was recrystallized from $\mathrm{CHCl}_{3} / \mathrm{MeOH}$ and the regiochemistry was determined by a single-crystal X-ray structure analysis. Mp: $152-155{ }^{\circ} \mathrm{C} .{ }^{1} \mathrm{H}$ NMR $(500$ $\left.\mathrm{MHz}_{\mathrm{CDCl}}\right) \delta: 1.40(18 \mathrm{H}, \mathrm{s}), 2.14(6 \mathrm{H}, \mathrm{s}), 6.33(2 \mathrm{H}, \mathrm{d}, J=1.0 \mathrm{~Hz}), 6.61(2 \mathrm{H}, \mathrm{brs})$. ${ }^{13} \mathrm{C} \mathrm{NMR}\left(125 \mathrm{MHz}, \mathrm{CDCl}_{3}\right) \delta: 21.9,32.2,34.3,114.5,127.0,137.4,143.9,148.5,150.9$. IR (neat): $2955 \mathrm{~cm}^{-1}$. HRMS (MALDI) Calcd for $\mathrm{C}_{22} \mathrm{H}_{28}[\mathrm{M}]^{+}:$292.2186. Found: 292.2186.<smiles>Cc1cc([Al])c2c(c1)-c1cc(C)cc(Cl)c1-2</smiles>

proximal-7i

1,8-Diadamantyl-3,6-dimethylbiphenylene (proximal-7i) (Table 1, entry 9 and Scheme 3)

From triflate 5i (Table 1, entry 9 and Scheme 3): Following the General Procedure I, 2-adamantyl-6-iodo-4-mehylphenyl trifluoromethanesulfonate (5i) (0.50 g, $1.0 \mathrm{mmol})$, and 1.1 M MeLi in $\mathrm{Et}_{2} \mathrm{O}(1.4 \mathrm{~mL}, 1.5 \mathrm{mmol})$ in $\mathrm{THF}(0.10 \mathrm{M}, 10 \mathrm{~mL})$ was stirred for 15 min at $-78{ }^{\circ} \mathrm{C}$. The reaction mixture was extracted with $\mathrm{CH}_{2} \mathrm{Cl}_{2}$ [proximal-7i/distal-7i $=$ $>20: 1,29 \%$ yield of $8 \mathbf{a}$ (see below), determined by ${ }^{1} \mathrm{H}$ NMR] and purified by column chromatography on silica gel (hexane including $1 \% \mathrm{Et}_{3} \mathrm{~N}$ ) to obtain the titled compound, proximal-7i (80 mg, 35\% isolated yield) as a colorless solid and a mixture of 8a (see below) and proximal-7i. The mixture was extracted with $2 \mathrm{~N} \mathrm{NaOH}$ and hexane. The organic phase was dried and concentrated under reduced pressure to obtain the titled 
compound, proximal-7i (40 mg, 19\% isolated yield). The product was recrystallized from $\mathrm{CHCl}_{3} / \mathrm{MeOH}$ and the regiochemistry was determined by a single-crystal X-ray structure analysis. Mp: 266-268 ${ }^{\circ} \mathrm{C} .{ }^{1} \mathrm{H} \mathrm{NMR}\left(500 \mathrm{MHz}, \mathrm{CDCl}_{3}\right) \delta: 1.71-1.80(12 \mathrm{H}, \mathrm{m}), 2.07$ (18 $\mathrm{H}$, brs), 2.13 (6 H, s), 6.29 (2 H, brs), 6.64 (2 H, brs). $\left.{ }^{13} \mathrm{C} \mathrm{NMR} \mathrm{(125} \mathrm{MHz,} \mathrm{CDCl}_{3}\right) \delta$ : 21.8, 28.9, 36.7, 36.9, 42.2, 113.8, 126.9, 136.9, 143.8, 149.3, 150.8. IR (neat): $2902 \mathrm{~cm}^{-}$ ${ }^{1}$. HRMS (MALDI) Calcd for $\mathrm{C}_{34} \mathrm{H}_{41}[\mathrm{M}+\mathrm{H}]^{+}$: 449.3203. Found: 449.3226.

From tosylate 5i' (Scheme 3): Following the General Procedure I, 2-adamantyl-6-iodo4-mehylphenyl tosylate (5i') (0.10 g, $0.19 \mathrm{mmol})$, and 1.1 M MeLi in $\mathrm{Et}_{2} \mathrm{O}(0.26 \mathrm{~mL}, 0.28$ mmol $)$ in THF $(0.10 \mathrm{M}, 1.9 \mathrm{~mL})$ was stirred for $15 \mathrm{~min}$ at $-78{ }^{\circ} \mathrm{C}$. The reaction mixture was extracted with hexane (proximal-7i/distal-7i $=>20: 1$ ) and purified by column chromatography on silica gel (hexane/ $\mathrm{CH}_{2} \mathrm{Cl}_{2}=9: 1$ ) to obtain the titled compound, proximal-7i (32 mg, 74\% isolated yield) as a yellow solid. The obtained solid was recrystallized from $\mathrm{CHCl}_{3} / \mathrm{MeOH}$ and the regiochemistry was determined by a singlecrystal X-ray structure analysis.

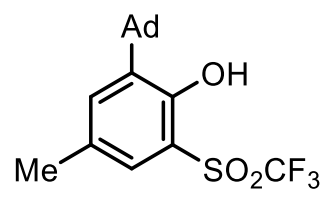

8a

2-((3r,5r,7r)-Adamantan-1-yl)-4-methyl-6-((trifluoromethyl)sulfonyl)phenol

(Scheme 3) was isolated as a pure form after the reaction shown below. Following the General Procedure I, 2-adamantyl-6-iodo-4-mehylphenyl trifluoromethanesulfonate (5i) (0.96 g, $1.9 \mathrm{mmol})$, and 1.1 M MeLi in $\mathrm{Et}_{2} \mathrm{O}(2.6 \mathrm{~mL}, 2.9 \mathrm{mmol})$ in THF (0.50 M, $\left.4 \mathrm{~mL}\right)$ was stirred for 15 min at $-78{ }^{\circ} \mathrm{C}$. The reaction mixture was extracted with $\mathrm{CH}_{2} \mathrm{Cl}_{2}$ and purified by column chromatography on silica gel (hexane including $1 \% \mathrm{Et}_{3} \mathrm{~N}$ ) to obtain the titled compound $8 \mathbf{a}(30 \mathrm{mg}, 3 \%)$ as a colorless solid. Mp: $136-139{ }^{\circ} \mathrm{C} .{ }^{1} \mathrm{H}$ NMR $(500$ $\left.\mathrm{MHz}, \mathrm{CDCl}_{3}\right) \delta: 1.75-1.80(6 \mathrm{H}, \mathrm{m}), 2.10(9 \mathrm{H}, \mathrm{brs}), 2.33(3 \mathrm{H}, \mathrm{s}), 7.38$ (1 H, brs), 7.44 $(1 \mathrm{H}, \mathrm{d}, J=2.5 \mathrm{~Hz}), 8.85$ (OH. s). ${ }^{13} \mathrm{C} \mathrm{NMR}\left(125 \mathrm{MHz}, \mathrm{CDCl}_{3}\right) \delta: 20.8,29.0,37.0,37.9$, $40.2,112.4,120.0(\mathrm{q}, J=320 \mathrm{~Hz}), 128.3,130.3,138.7,140.3,156.3 .{ }^{19} \mathrm{~F} \mathrm{NMR}(470 \mathrm{MHz}$, $\mathrm{CDCl}_{3}$ ) $\delta$ : -79.31. IR (neat): 3403, $2907 \mathrm{~cm}^{-1}$. HRMS (APCI) Calcd for $\mathrm{C}_{18} \mathrm{H}_{22} \mathrm{~F}_{3} \mathrm{O}_{3} \mathrm{Si}$ $[\mathrm{M}+\mathrm{H}]^{+}:$375.1236. Found: 375.1236. 


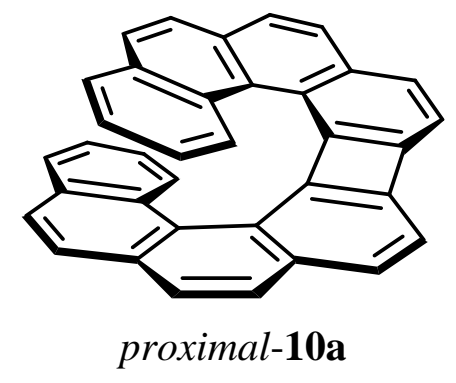

Biphenyleno[2,1-c:7,8-c']diphenanthrene (proximal-10a) (Table 2, entry 1): Following the General Procedure I, 2-iodobenzo[c]phenanthren-1-yl trifluoromethanesulfonate (13a) $(0.13 \mathrm{~g}, 0.26 \mathrm{mmol})$, and $1.1 \mathrm{M} \mathrm{MeLi}$ in $\mathrm{Et}_{2} \mathrm{O}(0.36 \mathrm{~mL}$, $0.39 \mathrm{mmol})$ in THF $(0.10 \mathrm{M}, 2.6 \mathrm{~mL})$ was stirred for $15 \mathrm{~min}$ at $-78{ }^{\circ} \mathrm{C}$. The reaction mixture was extracted with EtOAc and the residue (87\% yield, determined by ${ }^{1} \mathrm{H}$ NMR) was purified by column chromatography on silica gel (hexane/EtOAc $=5: 1$ ) to obtain the titled compound, proximal-10a (41 mg, 70\% isolated yield) as a dark red solid. The obtained product was recrystallized from $\mathrm{CHCl}_{3} / \mathrm{MeOH}$ and the regiochemistry was determined by a single-crystal X-ray structure analysis. Mp: >300 ${ }^{\circ} \mathrm{C} .{ }^{1} \mathrm{H}$ NMR $(500 \mathrm{MHz}$, $\left.\mathrm{CDCl}_{3}\right) \delta: 6.23(2 \mathrm{H}, \mathrm{ddd}, J=7.5,7.5,1.5 \mathrm{~Hz}), 6.71(2 \mathrm{H}, \mathrm{ddd}, J=7.5,7.5,1.0 \mathrm{~Hz}), 7.10$ $(2 \mathrm{H}, \mathrm{d}, J=7.0 \mathrm{~Hz}), 7.23(2 \mathrm{H}, \mathrm{d}, J=7.0 \mathrm{~Hz}), 7.28(2 \mathrm{H}, \mathrm{d}, J=8.5 \mathrm{~Hz}), 7.35-7.44(8 \mathrm{H}$, m), $7.72(2 \mathrm{H}, \mathrm{d}, J=8.5 \mathrm{~Hz}) .{ }^{13} \mathrm{C} \mathrm{NMR}\left(125 \mathrm{MHz}, \mathrm{CDCl}_{3}\right) \delta: 114.6,124.5,125.0,125.2$, $126.1,126.5,128.3,128.7,129.3,130.4,130.9,132.0,135.9,150.5,156.5$. IR (neat): $2917 \mathrm{~cm}^{-1}$. HRMS Calcd for $\mathrm{C}_{36} \mathrm{H}_{20}[\mathrm{M}]^{+}:$452.1560. Found: 452.1560.

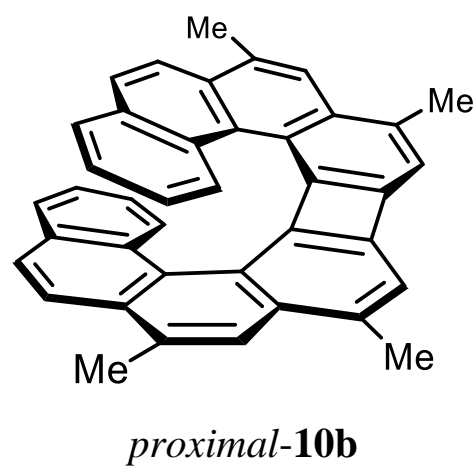

3,5,8,10-Tetramethylbiphenyleno[2,1-c:7,8-c']diphenanthrene

(proximal-10b)

(Table 2, entry 2): Following the General Procedure I, 2-bromo-4,6dimethylbenzo[c]phenanthren-1-yl trifluoromethanesulfonate (13b) $(9.0 \mathrm{mg}, 0.019$ 
$\mathrm{mmol})$, and $1.1 \mathrm{M} \mathrm{MeLi}$ in $\mathrm{Et}_{2} \mathrm{O}(0.028 \mathrm{~mL}, 0.031 \mathrm{mmol})$ in $\mathrm{THF}(0.10 \mathrm{M}, 0.19 \mathrm{~mL})$ was stirred for $15 \mathrm{~min}$ at $-78{ }^{\circ} \mathrm{C}$. The reaction mixture was extracted with $\mathrm{CH}_{2} \mathrm{Cl}_{2}$ and purified by column chromatography on silica gel (hexane/EtOAc $=20: 1$ ) to obtain the titled compound, proximal-10b (3.1 mg, 65\% isolated yield) as a dark red solid. The obtained product (proximal-10b) was recrystallized from $\mathrm{CHCl}_{3} / \mathrm{MeOH}$ and the regiochemistry was determined by a single-crystal X-ray structure analysis. Mp: $258-260{ }^{\circ} \mathrm{C} .{ }^{1} \mathrm{H}$ NMR $\left(500 \mathrm{MHz}, \mathrm{CDCl}_{3}\right) \delta: 2.62$ (12 H, brs), 6.16-6.19 (2 H, m), 6.64-6.67 (2 H, m), 6.93 (2 $\mathrm{H}, \mathrm{s}), 7.20(2 \mathrm{H}, \mathrm{d}, J=8.0 \mathrm{~Hz}), 7.36(2 \mathrm{H}, \mathrm{d}, J=8.5 \mathrm{~Hz}), 7.46(2 \mathrm{H}, \mathrm{s}), 7.55(2 \mathrm{H}, \mathrm{d}, J=$ $8.5 \mathrm{~Hz}), 7.63(2 \mathrm{H}, \mathrm{d}, J=8.0 \mathrm{~Hz}) .{ }^{13} \mathrm{C} \mathrm{NMR}\left(100 \mathrm{MHz}, \mathrm{CDCl}_{3}\right) \delta: 20.57,20.63,116.8$, 120.7, 123.5, 123.6, 124.8, 124.9, 126.2, 127.1, 128.3, 129.5, 130.2, 130.3, 130.7, 131.4, 132.8, 133.7, 148.9, 154.9. IR (neat): $1551,1435 \mathrm{~cm}^{-1}$. HRMS (MALDI) Calcd for $\mathrm{C}_{40} \mathrm{H}_{28}$ $[\mathrm{M}]^{+}:$508.2186. Found: 508.2202.

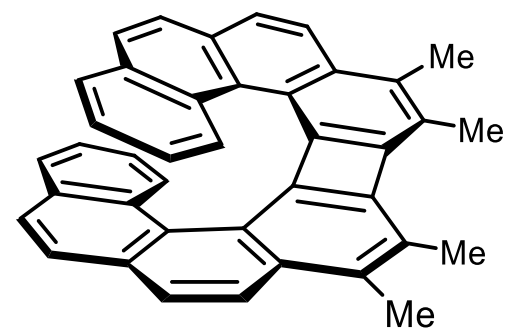

proximal-10c

5,6,7,8-Tetramethylbiphenyleno[2,1-c:7,8-c' $]$ diphenanthrene (proximal-10c) (Table

2, entry 3): Following the General Procedure I, 2-bromo-3,4dimethylbenzo[c]phenanthren-1-yl trifluoromethanesulfonate (13c) (34 mg, 0.070 mmol), and $1.1 \mathrm{M} \mathrm{MeLi}$ in $\mathrm{Et}_{2} \mathrm{O}(0.096 \mathrm{~mL}, 0.11 \mathrm{mmol})$ in THF $(0.10 \mathrm{M}, 0.70 \mathrm{~mL})$ was stirred for 15 min at $-78{ }^{\circ} \mathrm{C}$. The reaction mixture was extracted with EtOAc. The residue was washed with $\mathrm{Et}_{2} \mathrm{O}$ and the titled compound, proximal-10c (12 $\mathrm{mg}, 65 \%$ isolated yield) was obtained as a dark red solid. The mother liquor was evaporated and the residue was washed with $\mathrm{Et}_{2} \mathrm{O}$ again to obtain the titled compound, proximal-10c (1.7 $\mathrm{mg}, 9.5 \%$ isolated yield). Mp: $280-283{ }^{\circ} \mathrm{C} .{ }^{1} \mathrm{H}$ NMR $\left(500 \mathrm{MHz}, \mathrm{CDCl}_{3}\right) \delta: 2.66(12 \mathrm{H}$, brs), 6.21$6.24(2 \mathrm{H}, \mathrm{m}), 6.68-6.71(2 \mathrm{H}, \mathrm{m}), 7.23(2 \mathrm{H}, \mathrm{d}, J=8.0 \mathrm{~Hz}), 7.27-7.35$ (6 H, brs), 7.55 $(2 \mathrm{H}, \mathrm{d}, J=7.5 \mathrm{~Hz}), 7.74(2 \mathrm{H}, \mathrm{d}, J=8.5 \mathrm{~Hz}) .{ }^{13} \mathrm{C} \mathrm{NMR}\left(125 \mathrm{MHz}, \mathrm{CDCl}_{3}\right) \delta: 15.6,17.5$, 122.5 , 123.7, 124.6, 124.8, 125.0, 125.6, 126.4, 126.9, 128.1, 129.0, 129.7, 130.1, 131.9, 
133.3, 133.6, 150.1, 153.4. IR (neat): 1504, $1457 \mathrm{~cm}^{-1}$. HRMS (MALDI) Calcd for $\mathrm{C}_{40} \mathrm{H}_{28}$ $[\mathrm{M}]^{+}:$508.2186. Found: 508.2190.

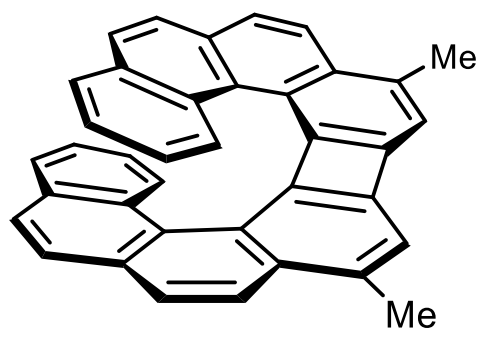

proximal-10d

5,8-Dimethylbiphenyleno[2,1-c:7,8-c']diphenanthrene (proximal-10d) (Table 2, entry 4): Following the General Procedure I, 2-iodo-4-methylbenzo[ $c]$ phenanthren-1-yl trifluoromethanesulfonate (13d) $(0.14 \mathrm{~g}, 0.27 \mathrm{mmol})$, and $1.1 \mathrm{M} \mathrm{MeLi}$ in $\mathrm{Et}_{2} \mathrm{O}(0.36 \mathrm{~mL}$, $0.40 \mathrm{mmol})$ in THF $(0.10 \mathrm{M}, 2.7 \mathrm{~mL})$ was stirred for $30 \mathrm{~min}$ at $-78{ }^{\circ} \mathrm{C}$. The reaction mixture was extracted with EtOAc. The residue was washed with $\mathrm{Et}_{2} \mathrm{O}$ and the solid material was recrystallized from $\mathrm{CHCl}_{3} / \mathrm{MeOH}$ to obtain the titled compound, proximal10d (37 mg, 58\% isolated yield) as a dark red needles. The mother liquor was evaporated and recrystallized again from $\mathrm{CHCl}_{3} / \mathrm{MeOH}$ to obtain the titled compound, proximal-10d (3.0 mg, 4\%). Mp: >300 ${ }^{\circ} \mathrm{C} .{ }^{1} \mathrm{H} \mathrm{NMR}\left(500 \mathrm{MHz}, \mathrm{CDCl}_{3}\right) \delta: 2.68(6 \mathrm{H}, \mathrm{s}), 6.23(2 \mathrm{H}, \mathrm{dd}$, $J=7.5,7.5 \mathrm{~Hz}), 6.70(2 \mathrm{H}, \mathrm{dd}, J=7.5,7.5 \mathrm{~Hz}), 7.02(2 \mathrm{H}, \mathrm{s}), 7.23(2 \mathrm{H}, \mathrm{d}, J=8.0 \mathrm{~Hz})$, $7.32-7.38(6 \mathrm{H}, \mathrm{m}), 7.64(2 \mathrm{H}, \mathrm{d}, J=8.5 \mathrm{~Hz}), 7.67(2 \mathrm{H}, \mathrm{d}, J=9.0 \mathrm{~Hz}) .{ }^{13} \mathrm{C}$ NMR $(125$ $\left.\mathrm{MHz}_{\mathrm{CDCl}}\right) \delta$ : 20.6, 116.9, 123.7, 124.0, 124.83, 124.88, 124.92, 125.5, 126.4, 126.7, $128.5,129.4,130.26,130.33,131.9,133.2,135.1,149.7,155.0$. IR (neat): 1507, 1473 $\mathrm{cm}^{-1}$. HRMS (MALDI) Calcd for $\mathrm{C}_{38} \mathrm{H}_{24}[\mathrm{M}]^{+}:$480.1873. Found: 480.1868. 


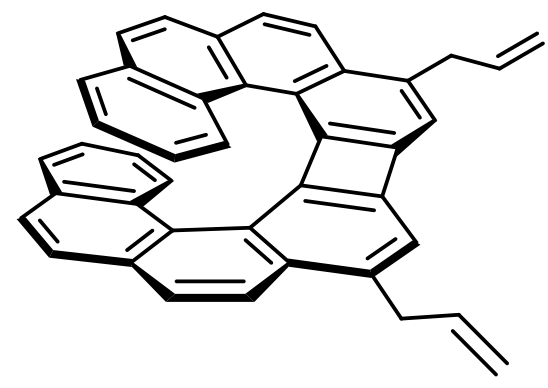

proximal-10e

5,8-Diallylbiphenyleno[2,1-c:7,8-c']diphenanthrene (proximal-10e) (Table 2, entry 5): Following the General Procedure I, 4-allyl-2-iodobenzo[c]phenanthren-1-yl trifluoromethanesulfonate (13e) $(59 \mathrm{mg}, 0.11 \mathrm{mmol})$, and $1.1 \mathrm{M} \mathrm{MeLi}$ in $\mathrm{Et}_{2} \mathrm{O}(0.15 \mathrm{~mL}$, $0.16 \mathrm{mmol})$ in THF $(0.10 \mathrm{M}, 1.1 \mathrm{~mL})$ was stirred for $30 \mathrm{~min}$ at $-78{ }^{\circ} \mathrm{C}$. The reaction mixture was extracted with EtOAc. The residue was washed with $\mathrm{Et}_{2} \mathrm{O}$ and the solid material was recrystallized from $\mathrm{CHCl}_{3} / \mathrm{MeOH}$ to obtain the titled compound, proximal10e (15 mg, 50\% isolated yield) as a dark red needles. The mother liquor was evaporated and recrystallized again from $\mathrm{CHCl}_{3} / \mathrm{MeOH}$ to obtain proximal-10e $(8.1 \mathrm{mg}, 28 \%$ isolated yield). Mp: 207-210 ${ }^{\circ} \mathrm{C} .{ }^{1} \mathrm{H}$ NMR (500 MHz, $\left.\mathrm{CDCl}_{3}\right) \delta: 3.75-3.84$ (4 H, m), 5.19-5.26 (4 H, m), 6.13-6.26 (4 H, m), 6.71 (2 H, ddd, J = 7.5, 7.5, 1.0 Hz), 7.05 (2 H, s), $7.23(2 \mathrm{H}, \mathrm{d}, J=8.0 \mathrm{~Hz}), 7.31-7.38(6 \mathrm{H}, \mathrm{m}), 7.64(2 \mathrm{H}, \mathrm{d}, J=9.0 \mathrm{~Hz}), 7.69(2 \mathrm{H}, \mathrm{d}$, $J=9.5 \mathrm{~Hz}) .{ }^{13} \mathrm{C} \mathrm{NMR}\left(125 \mathrm{MHz}, \mathrm{CDCl}_{3}\right) \delta: 38.4,116.3,116.5,123.6,124.4,124.9$, $125.11,125.15,126.0,126.6,126.9$, 128.7, 129.4, 130.4, 132.0, 133.2, 137.1, 137.2, 149.9, 155.5. IR (neat): $3049 \mathrm{~cm}^{-1}$. HRMS (MALDI) Calcd for $\mathrm{C}_{42} \mathrm{H}_{28}[\mathrm{M}]^{+}: 532.2186$. Found: 532.2181 .

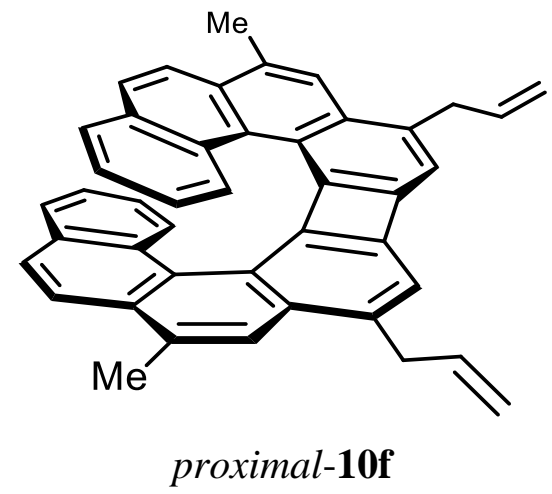

5,8-Diallyl-3,10-dimethylbiphenyleno[2,1-c:7,8-c']diphenanthrene (proximal-10f)

(Table 2, entry 6): Following the General Procedure I, 4-allyl-2- 
iodobenzo[c]phenanthren-1-yl trifluoromethanesulfonate (13e) $(39 \mathrm{mg}, 0.069 \mathrm{mmol}$ ), and $1.1 \mathrm{M} \mathrm{MeLi}$ in $\mathrm{Et}_{2} \mathrm{O}(0.095 \mathrm{~mL}, 0.10 \mathrm{mmol})$ in THF $(0.10 \mathrm{M}, 0.69 \mathrm{~mL})$ was stirred for 30 min at $-78^{\circ} \mathrm{C}$. The reaction mixture was extracted with EtOAc. The solid material was recrystallized from $\mathrm{CHCl}_{3} / \mathrm{MeOH}$ to obtain the titled compound, proximal-10f $(7.0$ $\mathrm{mg}, 36 \%$ isolated yield) as a red needles. The mother liquor was evaporated and the residue was added $0.30 \mathrm{M} \mathrm{MeLi}$ in $\mathrm{Et}_{2} \mathrm{O}(0.30 \mathrm{~mL}, 0.090 \mathrm{mmol})$ at $-78{ }^{\circ} \mathrm{C}$. The mixture was stirred for $30 \mathrm{~min}$ at $-78{ }^{\circ} \mathrm{C}$. After the addition of a saturated solution of $\mathrm{NH}_{4} \mathrm{Cl}$, the reaction mixture was extracted thrice with EtOAc. The solid material was recrystallized from $\mathrm{CHCl}_{3} / \mathrm{MeOH}$ to obtain the titled compound, proximal-10f $(7.3 \mathrm{mg}, 37 \%$ isolated yield) as a red needles. $\mathrm{Mp}:>300{ }^{\circ} \mathrm{C} .{ }^{1} \mathrm{H} \mathrm{NMR}\left(500 \mathrm{MHz}, \mathrm{CDCl}_{3}\right) \delta: 2.64(6 \mathrm{H}, \mathrm{s}), 3.76-$ 3.81 (4 H, m), 5.18-5.26 (4 H, m), 6.15-6.24 (4 H, m), 6.69 (2 H, ddd, $J=7.5,7.5,1.5$ Hz), $6.99(2 \mathrm{H}, \mathrm{s}), 7.24(2 \mathrm{H}, \mathrm{d}, J=7.5 \mathrm{~Hz}), 7.40(2 \mathrm{H}, \mathrm{d}, J=8.5 \mathrm{~Hz}), 7.51(2 \mathrm{H}, \mathrm{d}, J=$ $1.0 \mathrm{~Hz}), 7.58(2 \mathrm{H}, \mathrm{d}, J=8.5 \mathrm{~Hz}), 7.66(2 \mathrm{H}, \mathrm{d}, J=8.5 \mathrm{~Hz}) .{ }^{13} \mathrm{C} \mathrm{NMR}\left(125 \mathrm{MHz}, \mathrm{CDCl}_{3}\right)$ $\delta: 20.8,38.3,116.2,116.4,120.8,123.5,123.9,125.05,123.10,126.4,127.3,128.6,129.5$, 130.3, 130.4, 131.1, 131.6, 132.7, 135.8, 137.2, 149.1, 155.4. IR (neat): $3050 \mathrm{~cm}^{-1}$. HRMS (MALDI) Calcd for $\mathrm{C}_{44} \mathrm{H}_{32}[\mathrm{M}]^{+}:$560.2499. Found: 560.2498. 


\section{5-3. Preparation of precursors 5 and 13}

\section{5-3-1. General Procedures for the synthesis of 5 and 13:}

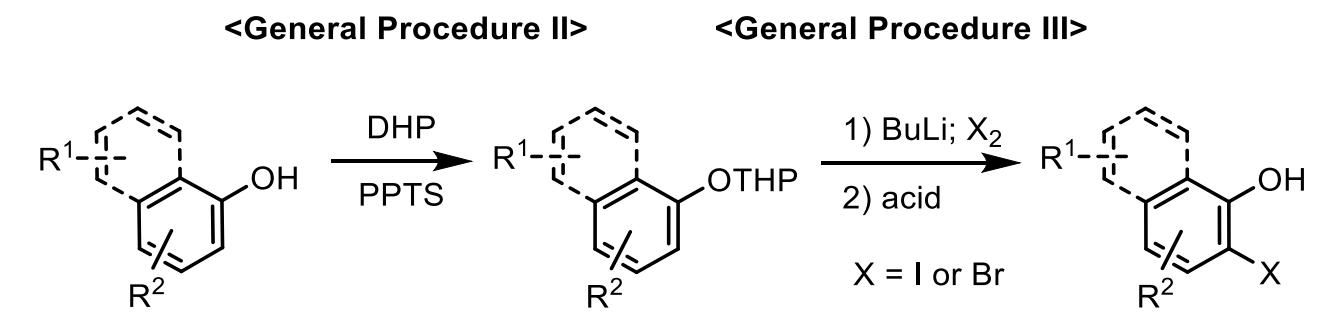

<General Procedure IV or V>

$<$ General Procedure VI>

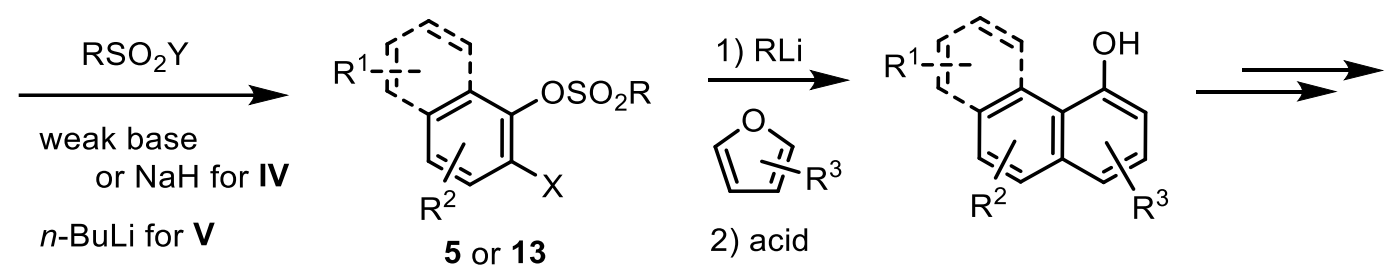

Scheme S3. Overall general synthesis of benzyne precursor 5 and 13.

General Procedure II (Protection using THP): An oven-dried flask with a magnetic stir bar equipped with an inlet adapter with three-way stopcock was evacuated and backfilled with Ar. Phenol derivative (1.0 equiv) and PTTS (0.10 equiv) were charged in the flask and evacuated and back-filled with Ar. Anhydrous $\mathrm{CH}_{2} \mathrm{Cl}_{2}(0.30 \mathrm{M})$ and DHP (10 equiv) were added to the flask via syringes at room temperature and stirred for indicated time. $2.0 \mathrm{~N} \mathrm{NaOH}$ solution was added to the mixture, and the mixture was extracted thrice with $\mathrm{CH}_{2} \mathrm{Cl}_{2}$. The combined organic phase was washed with brine. The organic phase was dried over $\mathrm{Na}_{2} \mathrm{SO}_{4}$, and the solvent was removed under reduced pressure. The crude product was roughly purified by flash column chromatography on silica gel (a mixture of hexane and EtOAc or $\mathrm{CH}_{2} \mathrm{Cl}_{2}$ ) to afford an aryl THP ether.

General Procedure III (Iodination using BuLi): An oven-dried flask with a magnetic stir bar equipped with an inlet adapter with three-way stopcock was evacuated and backfilled with Ar. The above obtained aryl THP ether (1.0 equiv) was charged in the flask and evacuated and back-filled with Ar. Anhydrous THF (0.30 M) was added to the flask via a syringe and cooled to $-78{ }^{\circ} \mathrm{C}$. $2.6 \mathrm{M} n$-BuLi solution in hexane (1.5 equiv) was 
added dropwise to the mixture at $-78^{\circ} \mathrm{C}$ via a syringe and the mixture was stirred for $15-$ $30 \mathrm{~min}$. The reaction was warmed to room temperature and stirred for indicated time. The mixture was cooled to $-78{ }^{\circ} \mathrm{C}$ again and $1.4 \mathrm{M}$ solution of $\mathrm{I}_{2}$ in THF (2.0 equiv) was added to the mixture dropwise. The reaction mixture was warmed to room temperature and stirred for indicated time. A saturated solution of $\mathrm{Na}_{2} \mathrm{~S}_{2} \mathrm{O}_{3}$ was added to the mixture, and the mixture was extracted thrice with $\mathrm{CH}_{2} \mathrm{Cl}_{2}$. The combined organic phase was washed with brine. The organic phase was dried over $\mathrm{Na}_{2} \mathrm{SO}_{4}$, and the solvent was removed under reduced pressure. The crude product was purified by flash column chromatography on silica gel (a mixture of hexane and EtOAc or $\mathrm{CH}_{2} \mathrm{Cl}_{2}$ ) to afford 2iodophenol derivative.

General Procedure IV (Sulfonylation using weak bases or NaH): An oven-dried flask with a magnetic stir bar equipped with an inlet adapter with three-way stopcock was evacuated and back-filled with Ar. 2-Halophenol derivative (1.0 equiv) [and ca. 60\% NaH in mineral oil] was [were] charged in the flask and evacuated and back-filled with Ar. Anhydrous THF or $\mathrm{Et}_{2} \mathrm{O}$ or $\mathrm{CH}_{2} \mathrm{Cl}_{2}(0.10-1.0 \mathrm{M})$, [weak base (1.0-1.5 equiv), ] and $\mathrm{Tf}_{2} \mathrm{O}$ or $p$ - $\mathrm{TsCl}\left(1.0-1.5\right.$ equiv) were added to the flask via syringes at $0{ }^{\circ} \mathrm{C}$ and stirred for indicated time. $\mathrm{H}_{2} \mathrm{O}$ was added to the mixture, and the mixture was extracted thrice with $\mathrm{Et}_{2} \mathrm{O}$, EtOAc, $\mathrm{CH}_{2} \mathrm{Cl}_{2}$ or hexane. The combined organic phase was washed with brine. The organic phase was dried over $\mathrm{Na}_{2} \mathrm{SO}_{4}$ or $\mathrm{MgSO}_{4}$, and the solvent was removed under reduced pressure. The crude product was purified by flash column chromatography on silica gel (a mixture of hexane and EtOAc or $\mathrm{CH}_{2} \mathrm{Cl}_{2}$ ) to afford aryl triflate (5 or $\mathbf{1 3}$ or substrate for the following step).

General Procedure V (Sulfonylation using $\boldsymbol{n}$-BuLi): An oven-dried flask with a magnetic stir bar equipped with an inlet adapter with three-way stopcock was evacuated and back-filled with Ar. 2-Halophenol derivative (1.0 equiv) was charged in the flask and evacuated and back-filled with Ar. Anhydrous THF or $\mathrm{Et}_{2} \mathrm{O}(0.10 \mathrm{M})$ was added to the flask via a syringe and cooled to $-78^{\circ} \mathrm{C} .2 .6 \mathrm{M} n$-BuLi solution in hexane (1.5 equiv) was added dropwise to the mixture at $-78^{\circ} \mathrm{C}$ via a syringe and the mixture was stirred for $15-$ 30 min. Thus, $\mathrm{Tf}_{2} \mathrm{O}$ or $p$ - $\mathrm{TsCl}\left(1.5\right.$ equiv) was added to the mixture and stirred at $-78^{\circ} \mathrm{C}$ for indicated time. A saturated solution of $\mathrm{NH}_{4} \mathrm{Cl}$ was added to the mixture, and the 
mixture was extracted thrice with $\mathrm{Et}_{2} \mathrm{O}$, EtOAc, $\mathrm{CH}_{2} \mathrm{Cl}_{2}$ or hexane. The combined organic phase was washed with brine. The organic phase was dried over $\mathrm{Na}_{2} \mathrm{SO}_{4}$ or $\mathrm{MgSO}_{4}$, and the solvent was removed under reduced pressure. The crude product was purified by flash column chromatography on silica gel (a mixture of hexane and EtOAc or $\mathrm{CH}_{2} \mathrm{Cl}_{2}$ ) to afford aryl triflate ( $\mathbf{5}$ or $\mathbf{1 3}$ or substrate for the following step).

General Procedure VI (Additional ring construction): An oven-dried flask with a magnetic stir bar equipped with an inlet adapter with three-way stopcock was evacuated and back-filled with Ar. 2-Halophenol derivative (1.0 equiv) was charged in the flask and evacuated and back-filled with Ar. Anhydrous THF (0.50 M) and furan derivative (3.0 equiv) were added to the flask via a syringe and cooled to $-78^{\circ} \mathrm{C} .1 .1 \mathrm{M} \mathrm{MeLi}$ solution in $\mathrm{Et}_{2} \mathrm{O}$ (2.0 equiv) was added dropwise to the mixture at $-78^{\circ} \mathrm{C}$ via a syringe and the mixture was stirred for $15-30 \mathrm{~min}$. The mixture was warmed to $0{ }^{\circ} \mathrm{C}$ and the mixture was extracted thrice with EtOAc or $\mathrm{Et}_{2} \mathrm{O}$. The organic phase was washed with brine and dried over $\mathrm{Na}_{2} \mathrm{SO}_{4}$. or $\mathrm{MgSO}_{4}$, and the solvent was removed under reduced pressure. The crude product was roughly purified by flash column chromatography on silica gel (a mixture of hexane and EtOAc or $\mathrm{CH}_{2} \mathrm{Cl}_{2}$ ) to afford 1,4-epoxy compound as a main product. To the mixture of the above mentioned product was added acid [6 $\mathrm{N} \mathrm{HCl}$ (8.2 equiv) or TMSOTf (4.2 equiv) or $\mathrm{BF}_{3} \cdot \mathrm{OEt}(0.5-1.5$ equiv)]. The mixture was stirred at room temperature for indicated time. $2 \mathrm{~N} \mathrm{NaOH}$ was added to the mixture to be neutralized. The mixture was extracted thrice with EtOAc, $\mathrm{CH}_{2} \mathrm{Cl}_{2}$ or hexane. The combined organic phase was washed with brine. The organic phase was dried over $\mathrm{Na}_{2} \mathrm{SO}_{4}$, and the solvent was removed under reduced pressure. The crude product was purified by flash column chromatography on silica gel (a mixture of hexane and EtOAc or $\mathrm{CH}_{2} \mathrm{Cl}_{2}$ ) to afford phenol derivative. 


\section{5-3-2. Spectroscopic and numerical data of benzyne precursors 5 and 13:}

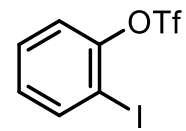

$5 \mathbf{a}$

2-Iodophenyl trifluoromethanesulfonate (5a) (Table 1, entry 1): ${ }^{[19]}$ Following the General Procedure IV, 2-iodophenenol (1.4 g, $6.2 \mathrm{mmol}),{ }^{[19]}$ pyridine $(0.75 \mathrm{~mL}, 9.3$ $\mathrm{mmol})$, and $\mathrm{Tf}_{2} \mathrm{O}(1.2 \mathrm{~mL}, 7.4 \mathrm{mmol})$ in anhydrous $\mathrm{CH}_{2} \mathrm{Cl}_{2}(21 \mathrm{~mL}, 0.31 \mathrm{M})$ and stirred for $15 \mathrm{~min}$ at room temperature. The mixture was extracted with $\mathrm{CH}_{2} \mathrm{Cl}_{2}$ and purified by flash column chromatography on silica gel (hexane/EtOAc $=10: 1$ ) to provide the titled compound 5a as a colorless oil (2.1 g, 95\%). ${ }^{1} \mathrm{H} \mathrm{NMR}\left(500 \mathrm{MHz}, \mathrm{CDCl}_{3}\right) \delta: 7.11(1 \mathrm{H}$, $\mathrm{dd}, J=8.0,8.0 \mathrm{~Hz}), 7.33(1 \mathrm{H}, \mathrm{dd}, J=8.0,1.5 \mathrm{~Hz}), 7.43(1 \mathrm{H}, \mathrm{dd}, J=8.0,8.0 \mathrm{~Hz}), 7.91$ $(1 \mathrm{H}, \mathrm{dd}, J=8.0,1.5 \mathrm{~Hz}) .{ }^{13} \mathrm{C} \mathrm{NMR}\left(125 \mathrm{MHz}, \mathrm{CDCl}_{3}\right) \delta: 89.2,118.8$ (q, $\left.J=320 \mathrm{~Hz}\right)$, $122.2,129.8,130.2,140.9,150.4$.<smiles>COc1ccccc1OC</smiles>

2-(2-Methoxyphenoxy)tetrahydro-2H-pyran: ${ }^{[20]}$ An oven dried flask with magnetic stir bar was charged with 2-methoxyphenenol (1.0 g, $8.1 \mathrm{mmol})$ and PPTS (20 mg, 0.81 mmol), and capped with an inlet adapter with 3-way stopcock. The flask was evacuated and back-filled with Ar. Anhydrous $\mathrm{CH}_{2} \mathrm{Cl}_{2}(7.0 \mathrm{~mL}, 1.2 \mathrm{M})$, and DHP (7.3 mL, 0.81 mmol) were added sequentially and the mixture was stirred at room temperature for 3.5 h. $1.0 \mathrm{M} \mathrm{NaOH}$ was added to the mixture at $0{ }^{\circ} \mathrm{C}$. The mixture was extracted thrice with EtOAc and the combined organic phase was washed with brine. The organic phase was dried over $\mathrm{Na}_{2} \mathrm{SO}_{4}$ and the filtrate was evaporated under reduced pressure. The residue was purified by flash column chromatography on silica gel (hexane/EtOAc $=10: 1$ ) to provide the titled compound as a colorless oil (1.8 g, quant). ${ }^{1} \mathrm{H} \mathrm{NMR}\left(500 \mathrm{MHz}, \mathrm{CDCl}_{3}\right)$

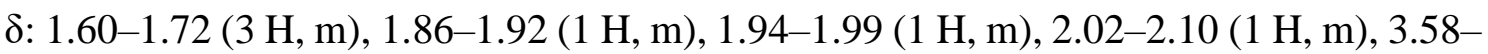
$3.62(1 \mathrm{H}, \mathrm{m}), 3.86(3 \mathrm{H}, \mathrm{s}), 4.00-4.04(1 \mathrm{H}, \mathrm{m}), 5.39(1 \mathrm{H}, J=3.5,3.5 \mathrm{~Hz}, \mathrm{dd}), 6.88-$ $6.92(2 \mathrm{H}, \mathrm{m}), 6.98(1 \mathrm{H}, J=1.5,7.5,7.5 \mathrm{~Hz}, \mathrm{ddd}), 7.14(1 \mathrm{H}, J=1.5,7.5 \mathrm{~Hz}, \mathrm{dd}) .{ }^{13} \mathrm{C}$ NMR $\left(100 \mathrm{MHz}, \mathrm{CDCl}_{3}\right) \delta: 18.6,25.0,30.1,55.6,61.8,97.3,112.1,117.7,120.6,122.3$, 
146.0, 150.1. IR (neat): $2945 \mathrm{~cm}^{-1}$. HRMS (MALDI) Calcd for $\mathrm{C}_{12} \mathrm{H}_{17} \mathrm{O}_{3}[\mathrm{M}+\mathrm{H}]^{+}$: 209.1172. Found: 209.1158.

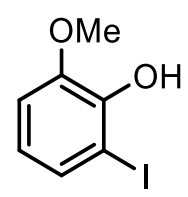

2-Iodo-6-methoxyphenol (Table 1, entry 2): An oven dried flask with magnetic stir bar was charged with 2-(2-methoxyphenoxy)tetrahydro- $2 H$-pyran $(1.7 \mathrm{~g}, 8.1 \mathrm{mmol})^{[20]}$ and capped with an inlet adapter with 3-way stopcock. The flask was evacuated and backfilled with Ar. Anhydrous THF (16 mL, 2.0 M), 2.8 M n-BuLi in hexane (4.7 mL, 12 mmol) were added and the mixture was stirred at $0{ }^{\circ} \mathrm{C}$ to allowed to warm to room temperature. $\mathrm{I}_{2}(2.0 \mathrm{~g}, 16 \mathrm{mmol})$ was added at $-78{ }^{\circ} \mathrm{C}$ and the mixture warmed to room temperature and stirred for $15 \mathrm{~h}$. The mixture was evaporated and the residue was extracted thrice with $\mathrm{CH}_{2} \mathrm{Cl}_{2}$ and the combined organic phase was washed with brine. The organic phase was dried over $\mathrm{Na}_{2} \mathrm{SO}_{4}$ and the filtrate was evaporated under reduced pressure. The residue was purified by flash column chromatography on silica gel (hexane/EtOAc $=5: 1)$ to provide crude product $(2.4 \mathrm{~g})$. The product was treated with $\mathrm{HCl}$ solution in $\mathrm{MeOH}$ and evaporated under reduced pressure. The mixture was purified by recrystallization to obtain the titled compound as a pale yellow solid ( $0.82 \mathrm{~g}, 41 \%)$. Mp: 48-51 ${ }^{\circ} \mathrm{C} .{ }^{1} \mathrm{H}$ NMR $\left(400 \mathrm{MHz}, \mathrm{CDCl}_{3}\right) \delta: 3.89(3 \mathrm{H}, \mathrm{s}), 6.10(\mathrm{OH}, \mathrm{s}), 6.63(1 \mathrm{H}, \mathrm{dd}, J=$ 8.0, 8.0 Hz), $6.83(1 \mathrm{H}, \mathrm{dd}, J=1.0,8.0 \mathrm{~Hz}), 7.29(1 \mathrm{H}, \mathrm{dd}, J=1.0,8.0 \mathrm{~Hz}) .{ }^{13} \mathrm{C} \mathrm{NMR}$ $\left(100 \mathrm{MHz} \mathrm{CDCl}_{3}\right) \delta: 56.2,81.4,110.6,121.6,130.6,145.7,146.2$. IR (neat): 2939, 3494 $\mathrm{cm}^{-1}$. HRMS (EI) Calcd for $\mathrm{C}_{7} \mathrm{H}_{7} \mathrm{O}_{2} \mathrm{I}[\mathrm{M}]^{+}:$249.9485. Found: 249.9490.

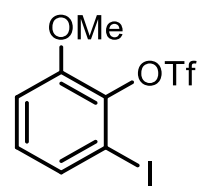

$5 \mathbf{b}$

2-Iodo-6-methoxyphenyl trifluoromethanesulfonate (5b) (Table 1, entry 2): Following the General Procedure IV, 2-iodo-6-methoxyphenol (0.80 mg, $3.2 \mathrm{mmol}), i$ $\operatorname{Pr}_{2} \mathrm{NEt}(1.1 \mathrm{~mL}, 6.4 \mathrm{mmol})$ and $\mathrm{Tf}_{2} \mathrm{O}(0.95 \mathrm{~mL}, 5.8 \mathrm{mmol})$ in $\mathrm{CH}_{2} \mathrm{Cl}_{2}(32 \mathrm{~mL}, 0.10 \mathrm{M})$ were mixed at $-78{ }^{\circ} \mathrm{C}$. The mixture was stirred for $15 \mathrm{~min}$ at room temperature and 
extracted with $\mathrm{CH}_{2} \mathrm{Cl}_{2}$. The crude product was purified by flash column chromatography on silica gel (hexane/EtOAc $=5: 1$ ) to provide the titled compound $\mathbf{5 b}$ as a pale yellow oil (1.0 g, 85\%). ${ }^{1} \mathrm{H} \mathrm{NMR}\left(400 \mathrm{MHz}, \mathrm{CDCl}_{3}\right) \delta: 3.89(3 \mathrm{H}, \mathrm{s}), 6.99(1 \mathrm{H}, \mathrm{dd}, J=2.0,8.0 \mathrm{~Hz})$, $7.03(1 \mathrm{H}, \mathrm{dd}, J=8.0,8.0 \mathrm{~Hz}), 7.43(1 \mathrm{H}, \mathrm{dd}, J=2.0,8.0 \mathrm{~Hz}) .{ }^{13} \mathrm{C} \mathrm{NMR}(100 \mathrm{MHz}$, $\left.\mathrm{CDCl}_{3}\right) \delta: 56.2,90.0,113.0,118.7(\mathrm{q}, J=321 \mathrm{~Hz}), 129.9,131.4,140.2,151.7 .{ }^{19} \mathrm{~F} \mathrm{NMR}$ (376 MHz, $\mathrm{CDCl}_{3}$ ) $\delta: 72.1$. IR (neat): $2948 \mathrm{~cm}^{-1}$. HRMS (EI) Calcd for $\mathrm{C}_{8} \mathrm{H}_{6} \mathrm{~F}_{3} \mathrm{O}_{4} \mathrm{SI}[\mathrm{M}]^{+}$: 381.8978. Found: 381.8979 .

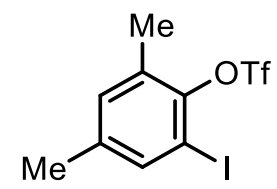

5c

2-Iodo-4,6-dimethylphenyl trifluoromethanesulfonate (5c) (Table 1, entry 3): Following the General Procedure V, 2-iodo-4,6-dimethylphenol (1.8 g, $7.3 \mathrm{mmol}),{ }^{[19]} 2.8$ $\mathrm{M} n$-BuLi in hexane $(2.7 \mathrm{~mL}, 7.7 \mathrm{mmol})$ and $\mathrm{Tf}_{2} \mathrm{O}(7.4 \mathrm{~mL}, 11 \mathrm{mmol})$ in $\mathrm{Et}_{2} \mathrm{O}(73 \mathrm{~mL}$, $1.0 \mathrm{M}$ ) was mixed at $-78{ }^{\circ} \mathrm{C}$. The mixture was stirred for $1 \mathrm{~h}$ at room temperature. The mixture was extracted with EtOAc. The crude product was purified by flash column chromatography on silica gel (hexane/EtOAc $=10: 1$ ) to provide the titled compound $\mathbf{5 c}$ as a colorless oil $(1.3 \mathrm{~g}, 47 \%) .{ }^{1} \mathrm{H}$ NMR $\left(500 \mathrm{MHz}, \mathrm{CDCl}_{3}\right) \delta: 2.29(3 \mathrm{H}, \mathrm{s}), 2.40(3 \mathrm{H}$, s), $7.05(1 \mathrm{H}, \mathrm{brs}), 7.56(1 \mathrm{H}, \mathrm{d}, J=1.0 \mathrm{~Hz}) .{ }^{13} \mathrm{C} \mathrm{NMR}\left(100 \mathrm{MHz}, \mathrm{CDCl}_{3}\right) \delta: 18.1,20.2$, 89.0, $118.6(\mathrm{q}, J=321 \mathrm{~Hz}), 132.6,133.1,139.2,139.8,146.4 .{ }^{19} \mathrm{~F}$ NMR $(376 \mathrm{MHz}$, $\mathrm{CDCl}_{3}$ ) $\delta: 72.1$. IR (neat): $2927 \mathrm{~cm}^{-1}$. HRMS (EI) Calcd for $\mathrm{C}_{9} \mathrm{H}_{8} \mathrm{~F}_{3} \mathrm{O}_{3} \mathrm{SI}[\mathrm{M}]^{+}: 379.9185$. Found: 379.9195.<smiles>Cc1cc(I)c(O)c(S(C)(=O)=O)c1</smiles>

2-Iodo-4-methyl-6-(trimethylsilyl)phenol (Table 1, entry 4): An oven dried flask with a magnetic stir bar was charged with 2,6-diiodo-4-methylphenol (1.4 g, $3.8 \mathrm{mmol}){ }^{[10]}$ and capped with an inlet adapter with 3-way stopcock. The flask was evacuated and backfilled with Ar. Anhydrous $\mathrm{CH}_{2} \mathrm{Cl}_{2}(6.0 \mathrm{~mL}, 0.60 \mathrm{M}), \mathrm{Et}_{3} \mathrm{~N}(0.57 \mathrm{~g}, 5.6 \mathrm{mmol})$, and TMSCl $(0.60 \mathrm{~g}, 5.6 \mathrm{mmol})$ were added to the mixture and stirred for $15 \mathrm{~min}$ at room temperature. 
The mixture was evaporated directly and the obtained residue was filtered through a celite pad using hexane. The filtrate was evaporated to produce 2,6-diiodo-4-methylphenyl trimethylsilyl ether (1.6 g, ca. 99\%) as a colorless oil, which was used for the next step without further purification. ${ }^{1} \mathrm{H} \mathrm{NMR}\left(500 \mathrm{MHz}, \mathrm{CDCl}_{3}\right) \delta: 0.47(9 \mathrm{H}, \mathrm{s}), 2.20(3 \mathrm{H}, \mathrm{s})$, 7.57 (2 H, s). ${ }^{13} \mathrm{C}$ NMR (100 MHz, $\left.\mathrm{CDCl}_{3}\right) \delta: 2.7,19.3,88.8,134.6,140.3$, 153.6. Anhydrous THF (7.5 mL, $0.40 \mathrm{M})$ was added to the flask with the above mentioned silyl ether $(1.3 \mathrm{~g})$ and cooled to $-78^{\circ} \mathrm{C} .2 .8 \mathrm{M} n$-BuLi in hexane $(1.6 \mathrm{~mL}, 4.5 \mathrm{mmol})$ was added and the mixture was stirred at $-78{ }^{\circ} \mathrm{C}$ for $15 \mathrm{~min}$. A saturated solution of $\mathrm{NH}_{4} \mathrm{Cl}$ was added to the mixture and the mixture was extracted thrice with EtOAc. The combined organic phase was dried over $\mathrm{Na}_{2} \mathrm{SO}_{4}$ evaporated by a rotary evaporator. The crude product was purified by flash column chromatography on silica gel (hexane) to provide the titled compound as a colorless oil $(0.59 \mathrm{~g}, 65 \%)$. Mp: $45-47{ }^{\circ} \mathrm{C} .{ }^{1} \mathrm{H}$ NMR $(500 \mathrm{MHz}$, $\left.\mathrm{CDCl}_{3}\right) \delta: 0.30(9 \mathrm{H}, \mathrm{s}), 2.25(3 \mathrm{H}, \mathrm{s}), 5.28(\mathrm{OH}, \mathrm{s}), 7.10(1 \mathrm{H}, \mathrm{d}, J=1.5 \mathrm{~Hz}), 7.48(1 \mathrm{H}$, $\mathrm{d}, J=1.5 \mathrm{~Hz}) .{ }^{13} \mathrm{C} \mathrm{NMR}\left(100 \mathrm{MHz}, \mathrm{CDCl}_{3}\right) \delta:-1.15,20.0,86.7,125.7,131.4,136.2$, 139.3, 156.4. IR (neat): 2954, $3497 \mathrm{~cm}^{-1}$. HRMS (EI) Calcd for $\mathrm{C}_{10} \mathrm{H}_{15} \mathrm{OSiI}[\mathrm{M}]^{+}$: 305.9931. Found: 305.9936.<smiles>CCCOc1c(I)cc(C)cc1OC</smiles>

5d

2-Iodo-4-methyl-6-(trimethylsilyl)phenyl trifluoromethanesulfonate (5d) (Table 1, entry 4): ${ }^{[21]}$ Following the General Procedure IV, 2-iodo-4-methyl-6(trimethylsilyl)phenol (0.44 g, $1.4 \mathrm{mmol})$, ca. 60\% NaH in mineral oil (0.12 g, $2.9 \mathrm{mmol})$ and $\mathrm{Tf}_{2} \mathrm{O}(0.54 \mathrm{~mL}, 2.9 \mathrm{mmol})$ in $\mathrm{Et}_{2} \mathrm{O}(5.0 \mathrm{~mL}, 0.30 \mathrm{M})$ were mixed at $-78{ }^{\circ} \mathrm{C}$ and stirred $1 \mathrm{~h}$ at room temperature. The mixture was extracted with $\mathrm{Et}_{2} \mathrm{O}$. The crude product was purified by flash column chromatography on silica gel (hexane). The product was washed with $1 \mathrm{~N} \mathrm{NaOH}$ solution and brine to provide the titled compound $\mathbf{5 d}$ as a colorless oil (0.59 g, 93\%). ${ }^{1} \mathrm{H}$ NMR (400 MHz, $\left.\mathrm{CDCl}_{3}\right) \delta: 0.37$ (9 H, s), 2.33 (3 H, s), 7.29-7.30 (1 $\mathrm{H}, \mathrm{m}), 7.73-7.74(1 \mathrm{H}, \mathrm{m}) .{ }^{13} \mathrm{C} \mathrm{NMR}\left(100 \mathrm{MHz}, \mathrm{CDCl}_{3}\right) \delta: 0.16,20.3,89.6,118.4(\mathrm{t}, \mathrm{J}=$ $321 \mathrm{~Hz}), 136.6,137.4,139.4,142.8,149.0 .{ }^{19} \mathrm{~F}$ NMR $\left(376 \mathrm{MHz}, \mathrm{CDCl}_{3}\right) \delta: 72.1 . \mathrm{IR}$ 
(neat): $2956 \mathrm{~cm}^{-1}$. HRMS (EI) Calcd for $\mathrm{C}_{11} \mathrm{H}_{14} \mathrm{~F}_{3} \mathrm{O}_{3} \mathrm{SSiI}[\mathrm{M}]^{+}$: 437.9424. Found: 437.9428 .<smiles>Cc1cc(I)c(OCC(C)(C)C)c(I)c1</smiles>

2,6-Diiodo-4-methylphenyl tert-butyldimethylsilyl ether (Table 1, entry 5): An oven dried flask with magnetic stir bar was charged with 2,6-diido-4-methylphenenol (2.2 g, $6.0 \mathrm{mmol})^{[10]}$ and imidazole $(1.6 \mathrm{~g}, 24 \mathrm{mmol})$, and capped with a reflux condenser and an inlet adapter with 3-way stopcock on the top. The flask was evacuated and back-filled with $\mathrm{N}_{2}$. Anhydrous $\mathrm{CH}_{2} \mathrm{Cl}_{2}(12 \mathrm{~mL}, 2.0 \mathrm{M})$, TBDMSCl (1.4 g, $\left.9.0 \mathrm{mmol}\right)$ were added sequentially and the mixture was stirred for $2 \mathrm{~h}$. After the reaction, the mixture was evaporated under reduced pressure. The residue was purified by flash column chromatography on silica gel (hexane) to provide the titled compound as a colorless oil (2.7 g, 96\%). ${ }^{1} \mathrm{H}$ NMR (500 MHz, $\left.\mathrm{CDCl}_{3}\right) \delta: 0.46(6 \mathrm{H}, \mathrm{s}), 1.07$ (9 H, s), $2.20(3 \mathrm{H}, \mathrm{s})$, $7.58(2 \mathrm{H}, \mathrm{s}) .{ }^{13} \mathrm{C} \mathrm{NMR}\left(100 \mathrm{MHz}, \mathrm{CDCl}_{3}\right) \delta:-0.1,18.9,19.3,26.6,88.5,134.5,140.7$, 152.9. IR (neat): $2928 \mathrm{~cm}^{-1}$. HRMS (APCI) Calcd for $\mathrm{C}_{13} \mathrm{H}_{21} \mathrm{I}_{2} \mathrm{OSi}[\mathrm{M}+\mathrm{H}]^{+}: 474.9446$. Found: 474.9418.<smiles>Cc1cc([AsH2])c(O)c(I)c1</smiles>

2-Iodo-4-methyl-6-(tert-butyldimethylsilyl)phenol (Table 1, entry 5): An oven dried flask with magnetic stir bar was charged with 2,6-iodo-4-methylphenenyl tertbutyldimethylsilyl ether $(2.5 \mathrm{~g}, 5.3 \mathrm{mmol})$ and capped with an inlet adapter with 3-way stopcock. The flask was evacuated and back-filled with $\mathrm{N}_{2}$. Anhydrous THF (13 mL, 0.4 M) and 2.8 $\mathrm{M} n$-BuLi in hexane $(2.8 \mathrm{~mL}, 7.4 \mathrm{mmol})$ were added sequentially and the mixture was stirred at $-78{ }^{\circ} \mathrm{C}$ for $15 \mathrm{~min}$. The mixture was stirred at room temperature for $1 \mathrm{~h}$ and a saturated $\mathrm{NH}_{4} \mathrm{Cl}$ solution was added to the mixture. The mixture was extracted thrice with $\mathrm{Et}_{2} \mathrm{O}$ and the combined organic phase was washed with brine. The organic phase was dried over $\mathrm{Na}_{2} \mathrm{SO}_{4}$ and the filtrate was evaporated under reduced pressure. The residue was purified by flash column chromatography on silica gel (hexane) 
to provide the titled compound as a colorless solid (1.3 g, 73\%). Mp: 58-60 ${ }^{\circ} \mathrm{C}$. ${ }^{1} \mathrm{H} \mathrm{NMR}$ $\left(500 \mathrm{MHz}, \mathrm{CDCl}_{3}\right)$ \&: $0.29(6 \mathrm{H}, \mathrm{s}), 0.90(9 \mathrm{H}, \mathrm{s}), 2.24(3 \mathrm{H}, \mathrm{s}), 5.26(\mathrm{OH}, \mathrm{s}), 7.08(1 \mathrm{H}$, $\mathrm{d}, J=2.0 \mathrm{~Hz}), 7.48(1 \mathrm{H}, \mathrm{d}, J=2.0 \mathrm{~Hz}) .{ }^{13} \mathrm{C} \mathrm{NMR}\left(100 \mathrm{MHz}, \mathrm{CDCl}_{3}\right) \delta:-4.69,17.6$, 20.0, 27.0, 87.1, 123.2, 131.0, 137.7, 139.4, 156.5. IR (neat): $2927 \mathrm{~cm}^{-1}$. HRMS (APCI) Calcd for $\mathrm{C}_{13} \mathrm{H}_{22} \mathrm{IOSi}[\mathrm{M}+\mathrm{H}]^{+}:$349.0479. Found: 349.0455 .

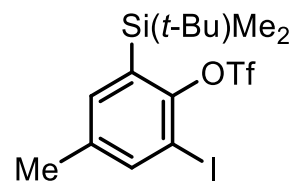

5 e

2-(tert-Butyldimethylsilyl)-6-iodo-4-methylphenyl trifluoromethanesulfonate (5e)

(Table 1, entry 5): Following the General Procedure IV, 2-iodo-4-methyl-6-(tertbutyldimethylsilyl)phenol (1.0 g, $2.9 \mathrm{mmol})$, ca. $60 \% \mathrm{NaH}$ in mineral oil (0.24 g, 5.9 $\mathrm{mmol})$ and $\mathrm{Tf}_{2} \mathrm{O}(1.1 \mathrm{~mL}, 5.9 \mathrm{mmol})$ in $\mathrm{Et}_{2} \mathrm{O}(10 \mathrm{~mL}, 0.30 \mathrm{M})$ were mixed at $-78^{\circ} \mathrm{C}$ and stirred for $1 \mathrm{~h}$ at room temperature. The mixture was extracted with $\mathrm{Et}_{2} \mathrm{O}$. The crude product was purified by flash column chromatography on silica gel (hexane) to provide the titled compound 5e as a colorless oil $(1.1 \mathrm{~g}, 78 \%) .{ }^{1} \mathrm{H} \mathrm{NMR}\left(500 \mathrm{MHz}, \mathrm{CDCl}_{3}\right) \delta$ : $0.38(6 \mathrm{H}, \mathrm{s}), 0.89(9 \mathrm{H}, \mathrm{s}), 2.32(3 \mathrm{H}, \mathrm{s}), 7.33(1 \mathrm{H}, \mathrm{d}, J=2.5 \mathrm{~Hz}), 7.75(1 \mathrm{H}, \mathrm{d}, J=2.5$ $\mathrm{Hz}) .{ }^{13} \mathrm{C}$ NMR $\left(100 \mathrm{MHz}, \mathrm{CDCl}_{3}\right) \delta:-3.57,18.2,20.3,27.2,89.5,118.5$ (q, $\left.J=321 \mathrm{~Hz}\right)$,

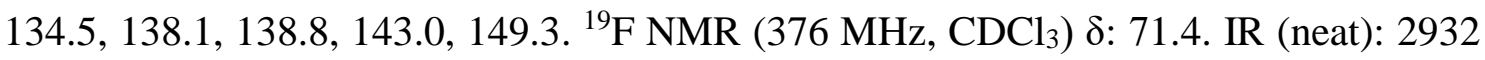
$\mathrm{cm}^{-1}$. HRMS (APCI) Calcd for $\mathrm{C}_{14} \mathrm{H}_{21} \mathrm{~F}_{3} \mathrm{IO}_{3} \mathrm{SSi}[\mathrm{M}+\mathrm{H}]^{+}$: 480.9972 . Found: 481.0001.<smiles>Cc1cc(I)c(O[GaH2])c(I)c1</smiles>

2,6-Diiodo-4-methylphenyl triisopropylsilyl ether (Table 1, entry 6): An oven dried flask with magnetic stir bar was charged with 2,6-diidopropylphenenol (4.3 g, 12 mmol) ${ }^{[10]}$ and imidazole $(3.2 \mathrm{~g}, 48 \mathrm{mmol})$, and capped with a reflux condenser and an inlet adapter with 3-way stopcock on the top. The flask was evacuated and back-filled with $\mathrm{N}_{2}$. Anhydrous $\mathrm{CH}_{2} \mathrm{Cl}_{2}(22 \mathrm{~mL}, 2.0 \mathrm{M})$, TIPSCl (3.4 g, $\left.18 \mathrm{mmol}\right)$ were added sequentially and the mixture was reflux for $10 \mathrm{~h}$. After the reaction, the mixture was evaporated under reduced pressure. The residue was purified by flash column 
chromatography on silica gel (hexane) to provide the titled compound as a colorless solid (6.0 g, 97\%). Mp: $135-137{ }^{\circ} \mathrm{C} .{ }^{1} \mathrm{H}$ NMR (400 MHz, $\left.\mathrm{CDCl}_{3}\right) \delta: 1.17(18 \mathrm{H}, \mathrm{d}, J=7.5 \mathrm{~Hz})$, $1.73(3 \mathrm{H}$, sext, $J=7.5 \mathrm{~Hz}), 2.18(3 \mathrm{H}, \mathrm{s}), 7.58(2 \mathrm{H}, \mathrm{s}) .{ }^{13} \mathrm{C} \mathrm{NMR}\left(100 \mathrm{MHz}, \mathrm{CDCl}_{3}\right) \delta$ : 15.2, 18.2, 19.2, 88.8, 134.1, 140.9, 154.3. IR (neat): $2944 \mathrm{~cm}^{-1}$. HRMS (APCI) Calcd for $\mathrm{C}_{16} \mathrm{H}_{27} \mathrm{I}_{2} \mathrm{OSi}[\mathrm{M}+\mathrm{H}]^{+}:$516.9915. Found: 516.9946 .<smiles>Cc1cc(I)c(O)c([Hg])c1</smiles>

2-Iodo-4-methyl-6-(triisopropylsilyl)phenol (Table 1, entry 6): An oven dried flask with magnetic stir bar was charged with 2,6-diiodo-4-methylphenenyl triisopropylsilyl ether $(0.92 \mathrm{~g}, 1.8 \mathrm{mmol})$ and capped with an inlet adapter with 3-way stopcock. The flask was evacuated and back-filled with Ar. Anhydrous THF (5.0 mL, 0.4 M) and 2.8 M nBuLi in hexane $(0.70 \mathrm{~mL}, 2.0 \mathrm{mmol})$ were added sequentially and the mixture was stirred at $-78{ }^{\circ} \mathrm{C}$ for $30 \mathrm{~min}$. The mixture was stirred at room temperature for $1 \mathrm{~h}$ and a saturated $\mathrm{NH}_{4} \mathrm{Cl}$ solution was added to the mixture. The mixture was extracted thrice with EtOAc and the combined organic phase was washed with brine. The organic phase was dried over $\mathrm{Na}_{2} \mathrm{SO}_{4}$ and the filtrate was evaporated under reduced pressure. The residue was purified by flash column chromatography on silica gel (hexane) to provide the titled compound as a colorless oil $(0.59 \mathrm{~g}, 85 \%) .{ }^{1} \mathrm{H}$ NMR $\left(400 \mathrm{MHz}, \mathrm{CDCl}_{3}\right) \delta: 1.08(18 \mathrm{H}, \mathrm{d}$, $J=8.0 \mathrm{~Hz}), 1.48(3 \mathrm{H}$, sept, $J=8.0 \mathrm{~Hz}), 2.25(3 \mathrm{H}, \mathrm{s}), 5.26(\mathrm{OH}, \mathrm{s}), 7.12(1 \mathrm{H}, \mathrm{d}, J=1.5$ $\mathrm{Hz}), 7.48(1 \mathrm{H}, \mathrm{d}, J=1.5 \mathrm{~Hz}) .{ }^{13} \mathrm{C} \mathrm{NMR}\left(100 \mathrm{MHz}, \mathrm{CDCl}_{3}\right) \delta: 11.6,18.8,20.1,87.0$, 121.2, 131.0, 138.1, 139.2, 156.6. IR (neat): 2865, $3493 \mathrm{~cm}^{-1}$. HRMS (APCI) Calcd for $\mathrm{C}_{16} \mathrm{H}_{28} \mathrm{IOSi}[\mathrm{M}+\mathrm{H}]^{+}:$391.0949. Found: 391.0921 .

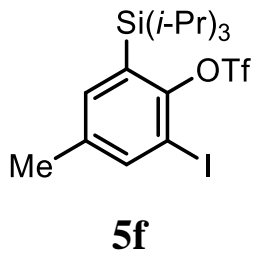

2-Iodo-4-methyl-6-(triisopropylsilyl)phenyl trifluoromethanesulfonate (5f) (Table 1, entry 6): Following the General Procedure IV, a mixture of 2-iodo-4-methyl-6(triisopropylsilyl)phenol (0.47 mg, $1.2 \mathrm{mmol})$, ca. 60\% $\mathrm{NaH}$ in mineral oil (58 mg, 1.5 
$\mathrm{mmol})$ and $\mathrm{Tf}_{2} \mathrm{O}(0.28 \mathrm{~mL}, 1.5 \mathrm{mmol})$ in $\mathrm{Et}_{2} \mathrm{O}(4.0 \mathrm{~mL}, 0.30 \mathrm{M})$ was stirred for $15 \mathrm{~h}$ at $78^{\circ} \mathrm{C}$. Additional ca. $60 \% \mathrm{NaH}$ in mineral oil $(39 \mathrm{mg}, 1.0 \mathrm{mmol})$ and $\mathrm{Tf}_{2} \mathrm{O}(0.20 \mathrm{~mL}, 1.0$ $\mathrm{mmol})$ in $\mathrm{Et}_{2} \mathrm{O}(4.0 \mathrm{~mL})$ were added and stirred for $1 \mathrm{~h}$ at room temperature. The mixture was extracted with $\mathrm{Et}_{2} \mathrm{O}$. The crude product was purified by flash column chromatography on silica gel (hexane) to provide the titled compound $\mathbf{5 f}$ as a pale yellow oil (0.25 g, 39\%). ${ }^{1} \mathrm{H}$ NMR (400 MHz, $\left.\mathrm{CDCl}_{3}\right) \delta: 1.11(18 \mathrm{H}, \mathrm{d}, J=7.5 \mathrm{~Hz}), 1.59(3 \mathrm{H}$, sext, $J=8.5 \mathrm{~Hz}), 2.33(3 \mathrm{H}, \mathrm{s}), 7.31(1 \mathrm{H}, \mathrm{d}, J=2.5 \mathrm{~Hz}), 7.78(1 \mathrm{H}, \mathrm{d}, J=2.5 \mathrm{~Hz}) .{ }^{13} \mathrm{C}$ NMR (100 MHz, $\left.\mathrm{CDCl}_{3}\right) \delta: 12.6,19.2,20.3,89.7,118.5$ (q, $\left.J=321 \mathrm{~Hz}\right), 133.2,138.4$, 138.9, 143.1, 149.4. ${ }^{19} \mathrm{~F}$ NMR (376 MHz, $\mathrm{CDCl}_{3}$ ) $\delta: 71.0$. IR (neat): $2869 \mathrm{~cm}^{-1}$. HRMS (CI) Calcd for $\mathrm{C}_{17} \mathrm{H}_{27} \mathrm{~F}_{3} \mathrm{O}_{3} \mathrm{SSiI}[\mathrm{M}+\mathrm{H}]^{+}:$523.0442. Found: 523.0437.<smiles>CCCc1cc(Br)c(Br)c(I)c1</smiles>

$5 g$

2-Iodo-4,6-diisopropylphenyl trifluoromethanesulfonate (5g) (Table 1, entry 7): Following the General Procedure V, 2-iodo-4,6-diisopropylphenol (1.2 g, $3.9 \mathrm{mmol})$, ${ }^{[22]}$ 2.6 $\mathrm{M} n$-BuLi in hexane $(1.5 \mathrm{~mL}, 4.1 \mathrm{mmol})$ and $\mathrm{Tf}_{2} \mathrm{O}(1.1 \mathrm{~mL}, 5.8 \mathrm{mmol})$ in anhydrous $\mathrm{Et}_{2} \mathrm{O}(3.9 \mathrm{~mL}, 1.0 \mathrm{M})$ was stirred for $1 \mathrm{~h}$ at $-78^{\circ} \mathrm{C}$. The mixture was extracted with EtOAc. The crude product was purified by flash column chromatography on silica gel (hexane) to provide the titled compound $\mathbf{5 g}$ as a pale yellow oil $(0.67 \mathrm{~g}, 39 \%) .{ }^{1} \mathrm{H}$ NMR $(500 \mathrm{MHz}$, $\left.\mathrm{CDCl}_{3}\right) \delta: 1.23(6 \mathrm{H}, \mathrm{d}, J=7.0 \mathrm{~Hz}), 1.24(6 \mathrm{H}, \mathrm{d}, J=7.0 \mathrm{~Hz}), 2.86(1 \mathrm{H}, \mathrm{sext}, J=7.0 \mathrm{~Hz})$, $3.34(1 \mathrm{H}, \operatorname{sext}, J=7.0 \mathrm{~Hz}), 7.18(1 \mathrm{H}, \mathrm{d}, J=2.0 \mathrm{~Hz}), 7.58(1 \mathrm{H}, \mathrm{d}, J=2.0 \mathrm{~Hz}) .{ }^{13} \mathrm{C} \mathrm{NMR}$ $\left(100 \mathrm{MHz} \mathrm{CDCl}_{3}\right) \delta: 23.6,23.7,28.3,33.5,89.2,118.6(\mathrm{q}, J=321 \mathrm{~Hz}), 126.2,136.7$, 143.5, 144.4, 150.9. ${ }^{19} \mathrm{~F}$ NMR (376 MHz, $\left.\mathrm{CDCl}_{3}\right) \delta: 71.8$. IR (neat): $2965 \mathrm{~cm}^{-1}$. HRMS (EI) Calcd for $\mathrm{C}_{13} \mathrm{H}_{16} \mathrm{~F}_{3} \mathrm{O}_{3} \mathrm{SI}[\mathrm{M}]^{+}$: 435.9811 . Found: 435.9813. 


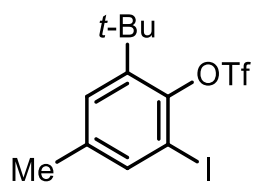

$5 \mathbf{h}$

\section{2-(tert-Butyl)-6-iodo-4-methylphenyl trifluoromethanesulfonate (5h) (Table 1, entry}

8): Following the General Procedure IV, 2-iodo-6-tert-butyl-4-methylphenenol (3.4 g, 12 mmol), ${ }^{[10]} i$ - $\operatorname{Pr}_{2} \mathrm{NEt}(4.1 \mathrm{~mL}, 23 \mathrm{~mol})$, and $\mathrm{Tf}_{2} \mathrm{O}(3.8 \mathrm{~mL}, 23 \mathrm{~mol})$ in $\mathrm{CH}_{2} \mathrm{Cl}_{2}(120 \mathrm{~mL}$, $0.015 \mathrm{M}$ ) was stirred for $2.5 \mathrm{~h}$ at $-78^{\circ} \mathrm{C}$ and stirred for $25 \mathrm{~h}$ at room temperature. The mixture was extracted with $\mathrm{CH}_{2} \mathrm{Cl}_{2}$. The crude product was purified by flash column chromatography on silica gel (hexane) to provide the titled compound $\mathbf{5} \mathbf{h}$ as a colorless oil (1.4 g, 29\%). ${ }^{1} \mathrm{H}$ NMR (400 MHz, $\left.\mathrm{CDCl}_{3}\right) \delta: 1.45(9 \mathrm{H}, \mathrm{s}), 2.31(3 \mathrm{H}, \mathrm{s}), 7.31(1 \mathrm{H}, \mathrm{d}$, $J=2.5 \mathrm{~Hz}), 7.61(1 \mathrm{H}, \mathrm{d}, J=2.5 \mathrm{~Hz}) .{ }^{13} \mathrm{C} \mathrm{NMR}\left(100 \mathrm{MHz}, \mathrm{CDCl}_{3}\right) \delta: 20.4,31.8,36.7$, 90.4, 118.5, (q, $J=321 \mathrm{~Hz}), 131.5,139.4,140.1,142.7,145.5 .{ }^{19} \mathrm{~F}$ NMR (376 MHz, $\mathrm{CDCl}_{3}$ ) $\delta:$ 70.1. IR (neat): $2971 \mathrm{~cm}^{-1}$. HRMS (APCI) Calcd for $\mathrm{C}_{12} \mathrm{H}_{14} \mathrm{~F}_{3} \mathrm{IO}_{3}[\mathrm{M}]^{+}$: 421.9655. Found: 421.9685.<smiles>Cc1cc(Cl)c(O)c(I)c1</smiles>

2-((3r,5r,7r)-Adamantan-1-yl)-6-iodo-4-methylphenol: A flask with magnetic stir bar was charged with 6-adamantyl-4-methylphenenol (4.1 g, $17 \mathrm{mmol}){ }^{[19]} 75 \%$ aqueous $\mathrm{AcOH}(170 \mathrm{~mL}, 0.10 \mathrm{M}), \mathrm{KI}(3.4 \mathrm{~g}, 20 \mathrm{mmol})$, and SPC (sodium percarbonate) $(5.8 \mathrm{~g}$, $37 \mathrm{mmol}$ ) and equipped with a reflux condenser. The mixture was stirred at $50{ }^{\circ} \mathrm{C}$ for 23 h. The mixture was cooled to room temperature and a saturated $\mathrm{Na}_{2} \mathrm{SO}_{3}$ solution was added to the mixture. The mixture was extracted thrice with $\mathrm{CH}_{2} \mathrm{Cl}_{2}$ and the combined organic phase was washed with brine. The organic phase was dried over $\mathrm{Na}_{2} \mathrm{SO}_{4}$ and the filtrate was evaporated under reduced pressure. The residue was purified by flash column chromatography on silica gel (hexane) to provide the titled compound as a colorless solid (4.8 g, 77\%). Mp: $148-150{ }^{\circ} \mathrm{C} .{ }^{1} \mathrm{H}$ NMR $\left(500 \mathrm{MHz}, \mathrm{CDCl}_{3}\right) \delta: 1.77$ (6 H, brs), $2.08(3 \mathrm{H}$, brs), 2.10 (6 H, brs), $2.24(3 \mathrm{H}, \mathrm{s}), 5.33(\mathrm{OH}, \mathrm{s}), 6.99(1 \mathrm{H}, \mathrm{d}, J=2.0 \mathrm{~Hz}), 7.35(1 \mathrm{H}, \mathrm{d}, J$ $=2.0 \mathrm{~Hz}) .{ }^{13} \mathrm{C} \mathrm{NMR}\left(125 \mathrm{MHz}, \mathrm{CDCl}_{3}\right) \delta: 20.5,29.2,37.2,37.6,40.4,89.7,128.7,131.3$, 
135.8, 136.9, 150.7. IR (neat): 2907, $3486 \mathrm{~cm}^{-1}$. HRMS (EI) Calcd for $\mathrm{C}_{17} \mathrm{H}_{21} \mathrm{OI}[\mathrm{M}]^{+}$: 3678.0632. Found: 368.0638 .

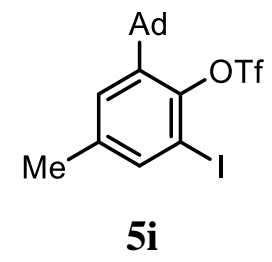

2-((3r,5r,7r)-Adamantan-1-yl)-6-iodo-4-methylphenyl trifluoromethanesulfonate (5i) (Table 1, entry 9 and Scheme 3): Following the General Procedure IV, 2-iodo-6adamantyl-4-methylphenenol (1.5 g, $4.1 \mathrm{mmol})$, ca. $60 \% \mathrm{NaH}$ in mineral oil (1.6 g, 41 $\mathrm{mmol})$, and $\mathrm{Tf}_{2} \mathrm{O}(3.8 \mathrm{~mL}, 23 \mathrm{mmol})$ in anhydrous $\mathrm{Et}_{2} \mathrm{O}(41 \mathrm{~mL}, 0.10 \mathrm{M})$ was stirred at $0{ }^{\circ} \mathrm{C}$ for $10 \mathrm{~min}$. The flask equipped with reflux condenser was stirred at room temperature for $30{ }^{\circ} \mathrm{C}$ for $14 \mathrm{~h}$ and $\mathrm{H}_{2} \mathrm{O}$ was added to the mixture at $0{ }^{\circ} \mathrm{C}$. The mixture was extracted with $\mathrm{Et}_{2} \mathrm{O}$ and purified by flash column chromatography on silica gel (hexane) and by GPC $\left(\mathrm{CHCl}_{3}\right)$ to provide the titled compound $\mathbf{5 i}$ as a pale yellow solid (1.6 g, 76\%). Mp: $126-127{ }^{\circ} \mathrm{C} .{ }^{1} \mathrm{H}$ NMR (500 MHz, $\left.\mathrm{CDCl}_{3}\right) \delta: 1.73-1.80$ (6 H, m), 2.09 $(3 \mathrm{H}, \mathrm{s}), 2.11$ (6 H, brs), $2.30(3 \mathrm{H}, \mathrm{s}), 7.35(1 \mathrm{H}, \mathrm{brs}), 7.60(1 \mathrm{H}, \mathrm{d}, J=1.5 \mathrm{~Hz}) .{ }^{13} \mathrm{C} \mathrm{NMR}$ $\left(125 \mathrm{MHz}, \mathrm{CDCl}_{3}\right) \delta: 20.5,29.0,36.3,39.5,42.1,90.5,118.5(\mathrm{q}, J=321 \mathrm{~Hz}), 131.1$, 139.3, 140.0, 142.7, 145.5. $\left.{ }^{19} \mathrm{~F} \mathrm{NMR} \mathrm{(470} \mathrm{MHz,} \mathrm{CDCl}_{3}\right) \delta:-70.68$. IR (neat): $2907 \mathrm{~cm}^{-1}$. HRMS (EI) Calcd for $\mathrm{C}_{18} \mathrm{H}_{20} \mathrm{~F}_{3} \mathrm{O}_{3} \mathrm{SI}[\mathrm{M}]^{+}:$500.0124. Found: 500.0133.

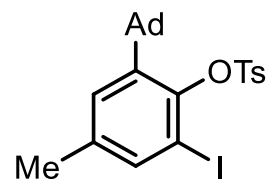

$5 \mathbf{i}$

\section{2-((3r,5r,7r)-Adamantan-1-yl)-6-iodo-4-methylphenyl 4-methylbenzenesulfonate}

(5i') (Scheme 3): Following the General Procedure IV, 2-iodo-6-adamantyl-4methylphenenol (1.0 g, $2.7 \mathrm{mmol})$, ca. $60 \% \mathrm{NaH}$ in mineral oil $(0.22 \mathrm{~g}, 5.4 \mathrm{mmol})$ and $p$ - TsCl $(0.77 \mathrm{~g}, 4.1 \mathrm{mmol})$ in THF $(27 \mathrm{~mL}, 0.10 \mathrm{M})$ was stirred at $0{ }^{\circ} \mathrm{C}$ for $4 \mathrm{~h}$ and stirred at room temperature for $10 \mathrm{~h}$. The mixture was extracted with $\mathrm{CH}_{2} \mathrm{Cl}_{2}$. The crude product was purified by flash column chromatography on silica gel (hexane/ $\mathrm{CH}_{2} \mathrm{Cl}_{2}=3: 2$ ) to provide the titled compound 5i' as a yellow solid (0.62 g, 43\%). Mp: $158-160{ }^{\circ} \mathrm{C} .{ }^{1} \mathrm{H}$ 
NMR (500 MHz, $\left.\mathrm{CDCl}_{3}\right) \delta:$ 1.70-1.76 (6 H, m), 2.06 (3 H, brs), 2.140-2.144 (6 H, m), $2.27(3 \mathrm{H}, \mathrm{s}), 2.47(3 \mathrm{H}, \mathrm{s}), 7.28(1 \mathrm{H}, \mathrm{d}, J=2.0 \mathrm{~Hz}), 7.36(2 \mathrm{H}, \mathrm{d}, J=8.5 \mathrm{~Hz}), 7.48(1 \mathrm{H}$, $\mathrm{d}, J=2.0 \mathrm{~Hz}), 7.89(2 \mathrm{H}, \mathrm{d}, J=8.5 \mathrm{~Hz}) .{ }^{13} \mathrm{C} \mathrm{NMR}\left(125 \mathrm{MHz}, \mathrm{CDCl}_{3}\right) \delta: 20.7,21.9,29.3$, 36.6, 39.2, 42.2, 92.1, 129.0, 129.7, 130.5, 135.7, 138.0, 139.2, 145.3, 145.9, 146.1. IR (neat): $2904 \mathrm{~cm}^{-1}$. HRMS (MALDI) Calcd for $\mathrm{C}_{24} \mathrm{H}_{27} \mathrm{O}_{3} \mathrm{NaSI}[\mathrm{M}+\mathrm{Na}]^{+}: 545.0618$. Found: 545.0636.<smiles>Brc1ccc2ccccc2c1Br</smiles>

1-Bromonaphthalen-2-yl trifluoromethanesulfonate (Table 2, entries 1-6):[23] Following the Genral Procedure IV, a mixture of 1-bromo-2-naphthol ${ }^{[19]}$ (38 g, 0.17 mol), pyridine $(25 \mathrm{~mL}, 0.31 \mathrm{~mol})$, and $\mathrm{Tf}_{2} \mathrm{O}(34 \mathrm{~mL}, 0.20 \mathrm{~mol})$ in anhydrous $\mathrm{CH}_{2} \mathrm{Cl}_{2}(170 \mathrm{~mL})$ was stirred at $0{ }^{\circ} \mathrm{C}$ for $15 \mathrm{~min}$. Then, $1 \mathrm{~N} \mathrm{HCl}(170 \mathrm{~mL})$ was carefully added at $0{ }^{\circ} \mathrm{C}$, and the mixture was extracted with $\mathrm{Et}_{2} \mathrm{O}(170 \mathrm{~mL})$ and purified by flash column chromatography on silica gel (hexane/EtOAc $=100: 1$ ) to provide the titled compound as a colorless oil (56 g, quant). ${ }^{1} \mathrm{H}$ NMR $\left(500 \mathrm{MHz}, \mathrm{CDCl}_{3}\right) \delta: 7.45(1 \mathrm{H}, \mathrm{d}, J=9.5 \mathrm{~Hz})$, 7.61-7.64 (1 H, m), 7.69-7.72 (1 H, m), 7.89-7.91 (2 H, m), 8.33 (1 H, d, J = 8.5 Hz). ${ }^{13} \mathrm{C}$ NMR $\left(125 \mathrm{MHz}, \mathrm{CDCl}_{3}\right) \delta: 116.2,118.7(\mathrm{q}, J=320 \mathrm{~Hz}), 119.9,127.73,127.75$, $128.3,128.8,129.7,132.6,133.0,145.0$.<smiles>Oc1cccc2ccc3ccccc3c12</smiles>

Phenanthren-4-ol (Table 2, entries 1, 3, 4 and 5): ${ }^{[24]}$ Following the General Procedure VI, a mixture of 1-bromonaphthalen-2-yl trifluoromethanesulfonate (26 g, $73 \mathrm{mmol}$ ), furan $(16 \mathrm{~mL}, 0.22 \mathrm{~mol})$, and $1.1 \mathrm{M} \mathrm{MeLi}$ in $\mathrm{Et}_{2} \mathrm{O}(100 \mathrm{~mL}, 0.11 \mathrm{~mol})$ was stirred in THF $(150 \mathrm{~mL}, 0.49 \mathrm{M})$ for $30 \mathrm{~min}$ at $-78{ }^{\circ} \mathrm{C} .6 \mathrm{~N} \mathrm{HCl}(100 \mathrm{~mL})$ was added to the mixture and stirred for $10 \mathrm{~h}$ at $30{ }^{\circ} \mathrm{C} .2 \mathrm{~N} \mathrm{NaOH}$ and a saturated $\mathrm{NaHCO}_{3}(100 \mathrm{~mL})$ solution were added until the reaction to be $\mathrm{pH}=9$, and the mixture was extracted once with ethyl acetate $(200 \mathrm{~mL})$. The crude product was purified by column chromatography on silica gel (hexane/toluene $=1: 1)$ to obtain the titled compound $(8.5 \mathrm{~g}, 59 \%)$ as a colorless solid. 
Mp: 95-98 ${ }^{\circ} \mathrm{C} .{ }^{1} \mathrm{H}$ NMR (300 MHz, $\left.\mathrm{CDCl}_{3}\right) \delta: 5.68(\mathrm{OH}, \mathrm{s}), 7.00(1 \mathrm{H}, \mathrm{dd}, J=7.5,1.5$ $\mathrm{Hz}), 7.43(1 \mathrm{H}, \mathrm{dd}, J=8.0,8.0 \mathrm{~Hz}), 7.52(1 \mathrm{H}, \mathrm{dd}, J=9.0,1.5 \mathrm{~Hz}), 7.56-7.75(4 \mathrm{H}, \mathrm{m})$, $7.89(1 \mathrm{H}, \mathrm{dd}, J=7.5,2.0 \mathrm{~Hz}), 9.64(1 \mathrm{H}, \mathrm{dd}, J=9.0,1.5 \mathrm{~Hz}) .{ }^{13} \mathrm{C} \mathrm{NMR}(125 \mathrm{MHz}$, CDCl3) $\delta: 113.2,119.4,121.7,126.0,126.3,126.5,126.7,128.0,128.2,128.5,130.2$, 132.5, 134.9, 154.3. IR (neat): $3522,1570 \mathrm{~cm}^{-1}$. HRMS (MALDI) Calcd for $\mathrm{C}_{14} \mathrm{H}_{10} \mathrm{O}$ $[\mathrm{M}]^{+}:$194.0726. Found: 194.0742.

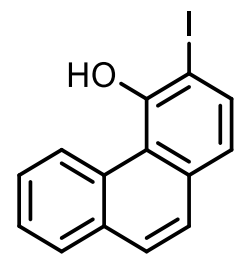

3-Iodophenanthren-4-ol (Table 2, entries 1, 3, 4 and 5): Following the General Procedure II, a mixture of phenanthren-4-ol (3.8 g, 19 mmol), PPTS (0.49 g, 1.9 mmol), and DHP (18 mL, $0.19 \mathrm{~mol})$ in anhydrous $\mathrm{CH}_{2} \mathrm{Cl}_{2}(64 \mathrm{~mL})$ was stirred at room temperature for $20 \mathrm{~h} .2 \mathrm{~N} \mathrm{NaOH}(20 \mathrm{~mL})$ was added, and the mixture was extracted once with $\mathrm{CH}_{2} \mathrm{Cl}_{2}(200 \mathrm{~mL})$ and roughly purified by flash column chromatography on silica gel (hexane/EtOAc $=9: 1)$ to provide 2-(phenanthren-4-yloxy)tetrahydro-2H-pyran (6.4 g) as a yellow solid. Following the General Procedure III, a mixture of the obtained impure 2-(phenanthren-4-yloxy)tetrahydro-2 $H$-pyran $(6.4 \mathrm{~g})$ and $2.8 \mathrm{M} n$-BuLi in hexane $(13 \mathrm{~mL}, 35 \mathrm{mmol})$ in anhydrous THF $(46 \mathrm{~mL})$ was stirred at room temperature for $45 \mathrm{~min}$ and stirred with $1.5 \mathrm{M} \mathrm{I}_{2}$ in THF $(33 \mathrm{~mL}, 46 \mathrm{mmol})$ for $14 \mathrm{~h}$. The crude product $(8.2 \mathrm{~g})$ and $6 \mathrm{~N} \mathrm{HCl}(16 \mathrm{~mL}, 96 \mathrm{mmol})$ in THF $(70 \mathrm{~mL})$ was stirred at room temperature for $1 \mathrm{~h}$. $2 \mathrm{~N} \mathrm{NaOH}(48 \mathrm{~mL})$ was added, and the mixture was extracted once with $\mathrm{CH}_{2} \mathrm{Cl}_{2}(300 \mathrm{~mL})$. The crude product was purified by column chromatography on silica gel (hexane) to obtain the titled compound ( $3.7 \mathrm{~g}, 59 \%$ overall yield from phenanthren-4-ol) as a yellow solid. Mp: $117-120{ }^{\circ} \mathrm{C} .{ }^{1} \mathrm{H}$ NMR $\left(500 \mathrm{MHz} \mathrm{CDCl}_{3}\right) \delta: 6.39(\mathrm{OH}, \mathrm{s}), 7.26(1 \mathrm{H}, \mathrm{d}, J=$ $8.5 \mathrm{~Hz}), 7.60-7.70(3 \mathrm{H}, \mathrm{m}), 7.77(1 \mathrm{H}, \mathrm{d}, J=9.0 \mathrm{~Hz}), 7.83(1 \mathrm{H}, \mathrm{d}, J=8.5 \mathrm{~Hz}), 7.89$ (1 $\mathrm{H}, \mathrm{dd}, J=7.5,1.5 \mathrm{~Hz}), 9.64(1 \mathrm{H}, \mathrm{d}, J=8.5 \mathrm{~Hz}) .{ }^{13} \mathrm{C} \mathrm{NMR}\left(125 \mathrm{MHz}, \mathrm{CDCl}_{3}\right) \delta: 85.4$, 119.3, 122.7, 126.4, 126.8, 128.3, 128.76, 128.84, 129.7, 132.6, 134.9, 135.1, 152.7. IR (neat): $3436 \mathrm{~cm}^{-1}$. HRMS (MALDI) Calcd for $\mathrm{C}_{14} \mathrm{H}_{9} \mathrm{OI}[\mathrm{M}]^{+}:$319.9693. Found: 319.9697. 
<smiles>Oc1c(I)ccc2ccc3ccccc3c12</smiles>

3-Iodophenanthren-4-yl 4-methylbenzenesulfonate (Table 2, entries 1, 3, 4 and 5): Following the General Procedure IV, a mixture of 3-iodophenanthren-4-ol (3.1 g, 9.7 $\mathrm{mmol}),(0.77 \mathrm{~g}, 19 \mathrm{mmol})$ and $p$-TsCl $(2.3 \mathrm{~g}, 12 \mathrm{mmol})$ in anhydrous THF (0.10 M, 48 $\mathrm{mL}$ ) was stirred at $0{ }^{\circ} \mathrm{C}$ for $1 \mathrm{~h}$. The mixture was stirred at room temperature for $4.5 \mathrm{~h}$ and $\mathrm{H}_{2} \mathrm{O}(20 \mathrm{~mL})$ was added to the mixture at $0{ }^{\circ} \mathrm{C}$. The mixture was extracted with $\mathrm{CH}_{2} \mathrm{Cl}_{2}$ and purified by flash column chromatography on silica gel (hexane/ $\mathrm{CH}_{2} \mathrm{Cl}_{2}=1: 2$ ) to provide the titled compound $(4.0 \mathrm{~g}, 87 \%)$ as a pale yellow solid. Mp: $148-149{ }^{\circ} \mathrm{C} .{ }^{1} \mathrm{H}$ $\operatorname{NMR}\left(500 \mathrm{MHz}, \mathrm{CDCl}_{3}\right) \delta: 2.26(3 \mathrm{H}, \mathrm{s}), 6.90(2 \mathrm{H}, \mathrm{d}, J=8.5 \mathrm{~Hz}), 7.29(1 \mathrm{H}, \mathrm{dd}, J=8.0$ $\mathrm{Hz}), 7.37(2 \mathrm{H}, \mathrm{d}, J=8.5 \mathrm{~Hz}), 7.43(1 \mathrm{H}, \mathrm{dd}, J=8.0 \mathrm{~Hz}), 7.48(1 \mathrm{H}, \mathrm{d}, J=8.5 \mathrm{~Hz}), 7.57$ $(1 \mathrm{H}, \mathrm{d}, J=8.5 \mathrm{~Hz}), 7.64(1 \mathrm{H}, \mathrm{d}, J=8.5 \mathrm{~Hz}), 7.69(1 \mathrm{H}, \mathrm{d}, J=8.0 \mathrm{~Hz}), 7.97(1 \mathrm{H}, \mathrm{d}, J=$ $8.5 \mathrm{~Hz}), 8.89(1 \mathrm{H}, \mathrm{d}, J=8.0 \mathrm{~Hz}) .{ }^{13} \mathrm{C} \mathrm{NMR}\left(125 \mathrm{MHz}, \mathrm{CDCl}_{3}\right) \delta: 21.5,91.9,125.5$, 125.6, 126.2, 126.9, 127.7, 128.2, 128.1, 128.5, 128.6, 128.8, 129.0, 132.4, 133.1, 134.2, 137.0, 145.3, 147.2. IR (neat): $3050 \mathrm{~cm}^{-1}$. HRMS (MALDI) Calcd for $\mathrm{C}_{21} \mathrm{H}_{15} \mathrm{O}_{3} \mathrm{NaSI}$ $[\mathrm{M}+\mathrm{Na}]^{+}:$496.9679. Found: 496.9679 .

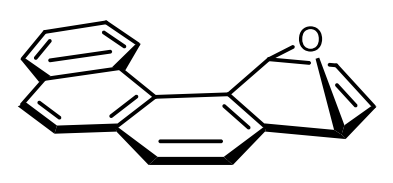

1,4-Dihydro-1,4-epoxybenzo[c]phenanthrene (Table 2, entry 1): Following the General Procedure VI, a mixture of 3-iodophenanthren-4-yl 4-methylbenzenesulfonate (7.8 g, $16 \mathrm{mmol})$, furan $(5.9 \mathrm{~mL}, 82 \mathrm{mmol})$, and $1.1 \mathrm{M} \mathrm{MeLi}$ in $\mathrm{Et}_{2} \mathrm{O}(30 \mathrm{~mL}, 33 \mathrm{mmol})$ was stirred in THF $(0.50 \mathrm{M}, 32 \mathrm{~mL})$ for $30 \mathrm{~min}$ at $-78{ }^{\circ} \mathrm{C}$. The mixture was stirred at room temperature for $15 \mathrm{~h}$. A saturated $\mathrm{NH}_{4} \mathrm{Cl}$ solution $(30 \mathrm{~mL})$ was added at $0{ }^{\circ} \mathrm{C}$. The crude product was purified by column chromatography on silica gel (hexane/ $\mathrm{CH}_{2} \mathrm{Cl}_{2}=$ $1: 1)$ to obtain the titled compound $(2.8 \mathrm{~g}, 70 \%)$ as a reddish orange solid. Mp: $128-129^{\circ} \mathrm{C}$.

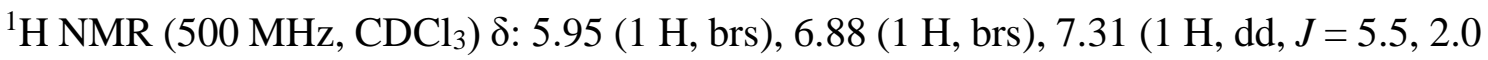
Hz), 7.45 (1 H, dd, $J=5.5,2.0 \mathrm{~Hz}), 7.59-7.65$ (4 H, m), 7.68-7.72 (2 H, m), 7.89 (1 H, $\mathrm{d}, J=7.5 \mathrm{~Hz}), 8.48(1 \mathrm{H}, \mathrm{d}, J=8.0 \mathrm{~Hz}) .{ }^{13} \mathrm{C} \mathrm{NMR}\left(125 \mathrm{MHz}, \mathrm{CDCl}_{3}\right) \delta: 82.2,84.1,119.3$, 
$125.4,126.0,126.1,126.5,126.7,127.7,128.6,129.8,130.7,132.8,142.5,145.2,147.2$, 148.8. IR (neat): $3049 \mathrm{~cm}^{-1}$. HRMS (MALDI) Calcd for $\mathrm{C}_{18} \mathrm{H}_{13} \mathrm{O}[\mathrm{M}+\mathrm{H}]^{+}: 245.0961$. Found: 245.0961.

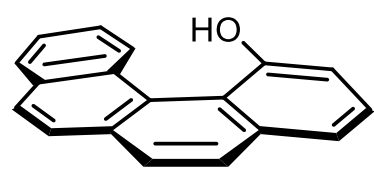

4-Methylbenzo[c]phenanthren-1-ol (Table 2, entry 1): Following the General Procedure VI, a mixture of 1,4-dihydro-1,4-epoxybenzo[c]phenanthrene (2.8 g, $11 \mathrm{mmol})$, TMSOTf $(8.3 \mathrm{~mL}, 46 \mathrm{mmol})$ was stirred in THF $(23 \mathrm{~mL}, 0.49 \mathrm{M})$ for $1 \mathrm{~h}$ at $0{ }^{\circ} \mathrm{C}$ and stirred for $1 \mathrm{~h}$ at room temperarture. A saturated $\mathrm{NaHCO}_{3}$ solution $(30 \mathrm{~mL})$ was added to the reaction solution. The crude product was purified by column chromatography on silica gel (hexane $\left./ \mathrm{CH}_{2} \mathrm{Cl}_{2}=1: 1\right)$ to obtain the titled compound $(0.86 \mathrm{~g}, 30 \%)$ as a yellow solid. Mp: $127-128{ }^{\circ} \mathrm{C} .{ }^{1} \mathrm{H}$ NMR (500 MHz, $\left.\mathrm{CDCl}_{3}\right) \delta: 5.54(\mathrm{OH}, \mathrm{s}), 7.25(1 \mathrm{H}, \mathrm{dd}, J=7.0,2.0$ Hz), 7.61-7.67 (3 H, m), 7.71 (1 H, ddd, $J=8.0,8.0,1.5 \mathrm{~Hz}), 7.77(1 \mathrm{H}, \mathrm{d}, J=8.5 \mathrm{~Hz})$, $7.90(1 \mathrm{H}, \mathrm{d}, J=8.5 \mathrm{~Hz}), 7.99(1 \mathrm{H}, \mathrm{d}, J=8.5 \mathrm{~Hz}), 8.07(1 \mathrm{H}, \mathrm{d}, J=7.5 \mathrm{~Hz}), 8.19(1 \mathrm{H}$, $\mathrm{d}, J=8.5 \mathrm{~Hz}) .{ }^{13} \mathrm{C} \mathrm{NMR}\left(125 \mathrm{MHz}, \mathrm{CDCl}_{3}\right) \delta: 113.1,118.0,120.4,123.9,126.18,126.29$, $126.30,126.7,127.4,127.55,127.58,127.8,128.1,128.5,131.8,132.9,135.0$ 152.5. IR (neat): $3523 \mathrm{~cm}^{-1}$. HRMS (MALDI) Calcd for $\mathrm{C}_{18} \mathrm{H}_{12} \mathrm{O}[\mathrm{M}]^{+}: 244.0883$. Found: 244.0888.

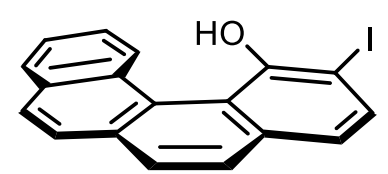

2-Iodobenzo[c]phenanthren-1-ol (Table 2, entry 1): Following the General Procedure II, a mixture of 4-methylbenzo[c]phenanthren-1-ol (76 mg, $0.31 \mathrm{mmol})$, PPTS (7.5 mg, $0.031 \mathrm{mmol})$, and DHP $(0.27 \mathrm{~mL}, 3.1 \mathrm{mmol})$ in anhydrous $\mathrm{CH}_{2} \mathrm{Cl}_{2}(3.1 \mathrm{~mL}, 0.10 \mathrm{M})$ was stirred at room temperature for 17 h. $2 \mathrm{~N} \mathrm{NaOH}(1 \mathrm{~mL})$ was added, and the mixture was extracted once with $\mathrm{CH}_{2} \mathrm{Cl}_{2}(10 \mathrm{~mL})$ and roughly purified by flash column chromatography on silica gel (hexane/EtOAc $=9: 1)$ to provide 2-(benzo[c]phenanthren1-yloxy)tetrahydro-2H-pyran (99 mg) as a yellow solid. Following the General Procedure III, a mixture of impure 2-(benzo[c]phenanthren-1-yloxy)tetrahydro-2 $H$-pyran (99 mg) and $2.8 \mathrm{M} n$-BuLi in hexane $(0.16 \mathrm{~mL}, 0.45 \mathrm{mmol})$ in anhydrous THF $(0.60 \mathrm{~mL})$ was 
stirred at room temperature for $45 \mathrm{~min}$ and stirred with $1.5 \mathrm{M} \mathrm{I}_{2}$ in THF $(0.40 \mathrm{~mL}, 0.60$ $\mathrm{mmol}$ ) for $22 \mathrm{~h}$ at room temperature. The residue was roughly purified by column chromatography on silica gel (hexane/EtOAc $=5: 1)$. The crude product $(0.12 \mathrm{~g})$ and $6 \mathrm{~N}$ $\mathrm{HCl}(0.15 \mathrm{~mL}, 0.90 \mathrm{mmol})$ in THF $(1.0 \mathrm{~mL})$ was stirred at room temperature for $37 \mathrm{~h} .2 \mathrm{~N}$ $\mathrm{NaOH}(0.40 \mathrm{~mL}, 0.80 \mathrm{mmol})$ was added, and the mixture was extracted once with $\mathrm{CH}_{2} \mathrm{Cl}_{2}$ (20 mL). The crude product was purified by column chromatography on silica gel (hexane/ $\mathrm{CH}_{2} \mathrm{Cl}_{2}=1: 1$ ) was obtained as a yellow solid (63 mg, $56 \%$ overall yield from 4methylbenzo[c]phenanthren-1-ol). Mp: $117-120{ }^{\circ} \mathrm{C} .{ }^{1} \mathrm{H}$ NMR $\left(500 \mathrm{MHz}, \mathrm{CDCl}_{3}\right) \delta: 6.17$ $(\mathrm{OH}, \mathrm{s}), 7.39(1 \mathrm{H}, \mathrm{d}, J=8.5 \mathrm{~Hz}), 7.62-7.70(2 \mathrm{H}, \mathrm{m}), 7.80(1 \mathrm{H}, \mathrm{d}, J=8.0 \mathrm{~Hz}), 7.83-$ $7.86(2 \mathrm{H}, \mathrm{m}), 7.96-7.99(2 \mathrm{H}, \mathrm{m}), 8.03(1 \mathrm{H}, \mathrm{dd}, J=8.0,1.0 \mathrm{~Hz}), 8.16(1 \mathrm{H}, \mathrm{d}, J=8.5$ $\mathrm{Hz}) .{ }^{13} \mathrm{C}$ NMR $\left(125 \mathrm{MHz}, \mathrm{CDCl}_{3}\right) \delta: 82.6,118.2,121.9$ 124.5, 125.9, 126.4, 127.4, 128.2, 128.3, 128.5, 128.9, 132.1, 133.0, 135.3, 136.1, 151.5. IR (neat): $3510 \mathrm{~cm}^{-1}$. HRMS (FAB) Calcd for $\mathrm{C}_{18} \mathrm{H}_{11} \mathrm{OI}[\mathrm{M}]^{+}:$369.9849. Found: 369.9858 .

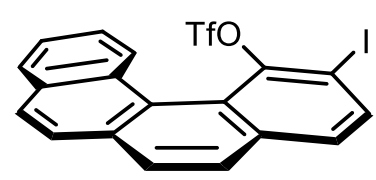

13a

\section{2-Iodobenzo $[c]$ phenanthren-1-yl trifluoromethanesulfonate (13a) (Table 2, entry 1):}

Following the General Procedure IV, a mixture of 2-iodobenzo[c]phenanthren-1-ol (0.13 $\mathrm{g}, 0.35 \mathrm{mmol})$, ca. $60 \% \mathrm{NaH}$ in mineral oil (0.14 g, $3.5 \mathrm{mmol})$, and $\mathrm{Tf}_{2} \mathrm{O}(0.23 \mathrm{~mL}, 1.4$ mmol) in anhydrous $\mathrm{CH}_{2} \mathrm{Cl}_{2}(3.4 \mathrm{~mL})$ was stirred at $0{ }^{\circ} \mathrm{C}$ for $10 \mathrm{~min}$. The flask was stirred at room temperature for $18 \mathrm{~h}$ and $\mathrm{H}_{2} \mathrm{O}(5 \mathrm{~mL})$ was added to the mixture at $0{ }^{\circ} \mathrm{C}$. The mixture was extracted with $\mathrm{CH}_{2} \mathrm{Cl}_{2}$ and purified by flash column chromatography on silica gel (hexane/EtOAc $=5: 1)$ to give the titled compound $(0.13 \mathrm{~g}, 75 \%)$ as a yellow solid. Mp: $133-134{ }^{\circ} \mathrm{C} .{ }^{1} \mathrm{H}$ NMR (500 MHz, $\left.\mathrm{CDCl}_{3}\right) \delta$ : 7.63-7.71 (2 H, m), $7.74(1 \mathrm{H}, \mathrm{d}$, $J=8.5 \mathrm{~Hz}), 7.82-7.85(2 \mathrm{H}, \mathrm{m}), 7.89(1 \mathrm{H}, \mathrm{d}, J=8.5 \mathrm{~Hz}), 8.00(1 \mathrm{H}, \mathrm{d}, J=8.0 \mathrm{~Hz}), 8.04$ $(1 \mathrm{H}, \mathrm{d}, J=8.5 \mathrm{~Hz}), 8.10(1 \mathrm{H}, \mathrm{d}, J=8.5 \mathrm{~Hz}), 8.18(1 \mathrm{H}, \mathrm{d}, J=8.5 \mathrm{~Hz}) .{ }^{13} \mathrm{C}$ NMR $(125$ $\left.\mathrm{MHz}, \mathrm{CDCl}_{3}\right) \delta: 89.81,117.7$ (q, $\left.320 \mathrm{~Hz}\right), 123.0,124.0,125.6,126.05,126.11,126.8$, $127.7,128.8,128.9,129.2,129.3,129.7,132.3,132.9,135.0,136.6,145.8 .{ }^{19} \mathrm{~F}$ NMR $(470$ $\mathrm{MHz}, \mathrm{CDCl}_{3}$ ) $\delta:-74.78$. IR (neat): $3052 \mathrm{~cm}^{-1}$. HRMS (EI) Calcd for $\mathrm{C}_{19} \mathrm{H}_{10} \mathrm{~F}_{3} \mathrm{O}_{3} \mathrm{SI}[\mathrm{M}]^{+}$: 501.9342. Found: 501.9357. 
<smiles>Cc1ccc(O)c2c1ccc1ccccc12</smiles>

1-Methylphenanthren-4-ol (Table 2, entries 2 and 6): Following the General Procedure VI, a mixture of 1-bromonaphthalen-2-yl trifluoromethanesulfonate (7.4 g, 21 mmol), 2-methylfuran (5.6 mL, $63 \mathrm{mmol})$, and 1.1 M MeLi in $\mathrm{Et}_{2} \mathrm{O}$ (38 mL, $42 \mathrm{mmol}$ ) was stirred in THF $(0.50 \mathrm{M}, 42 \mathrm{~mL})$ for $1 \mathrm{~h}$ at $-78{ }^{\circ} \mathrm{C}$ and stirred for $1 \mathrm{~h}$ at room temperature. $6 \mathrm{~N} \mathrm{HCl}(30 \mathrm{~mL})$ was added to the reaction solution, and the mixture was stirred for $23 \mathrm{~h}$. To the reaction mixture, $2 \mathrm{~N} \mathrm{NaOH}(80 \mathrm{~mL})$ was added. The crude product was purified by column chromatography on silica gel (hexane $/ \mathrm{CH}_{2} \mathrm{Cl}_{2}=1: 1$ ) to obtain the titled compound $(1.8 \mathrm{~g}, 41 \%)$ as a yellow solid. Mp: $100-102{ }^{\circ} \mathrm{C} .{ }^{1} \mathrm{H}$ NMR (400 MHz, $\left.\mathrm{CDCl}_{3}\right) \delta: 2.70(3 \mathrm{H}, \mathrm{s}), 5.59(\mathrm{OH}, \mathrm{s}), 6.87(1 \mathrm{H}, \mathrm{d}, J=7.5 \mathrm{~Hz}), 7.28(1 \mathrm{H}, \mathrm{d}, J=7.5 \mathrm{~Hz})$, $7.62(1 \mathrm{H}, \mathrm{ddd}, J=8.0,8.0,1.5 \mathrm{~Hz}), 7.69(1 \mathrm{H}, \mathrm{ddd}, J=8.0,8.0,1.5 \mathrm{~Hz}), 7.81(1 \mathrm{H}, \mathrm{d}, J$ $=9.0 \mathrm{~Hz}), 7.92(1 \mathrm{H}, \mathrm{d}, J=9.0 \mathrm{~Hz}), 7.93(1 \mathrm{H}, \mathrm{dd}, J=8.0,1.5 \mathrm{~Hz}), 9.73(1 \mathrm{H}, \mathrm{brd}, J=$ $8.0 \mathrm{~Hz}) .{ }^{13} \mathrm{C} \mathrm{NMR}\left(125 \mathrm{MHz}, \mathrm{CDCl}_{3}\right) \delta: 19.8,112.6,119.5,123.0,125.9,126.4,127.0$, 127.4, 127.8, 128.1, 128.6, 130.6, 132.2, 133.0, 152.8. IR (neat): $3447,1636 \mathrm{~cm}^{-1}$. HRMS (MALDI) Calcd for $\mathrm{C}_{15} \mathrm{H}_{12} \mathrm{O}[\mathrm{M}]^{+}: 208.0883$. Found: 208.0883.<smiles>Cc1cc(I)c(O)c2c1ccc1ccccc12</smiles>

3-Iodo-1-methylphenanthren-4-ol (Table 2, entries 2 and 6): Following the General Procedure II, a mixture of 1-methylphenanthren-4-ol (2.8 g, 13 mmol), PPTS (0.33 g, 1.3 $\mathrm{mmol})$, and DHP (12 mL, $0.13 \mathrm{~mol})$ in anhydrous $\mathrm{CH}_{2} \mathrm{Cl}_{2}(44 \mathrm{~mL})$ was stirred at room temperature for $20 \mathrm{~h} .2 \mathrm{~N} \mathrm{NaOH}(20 \mathrm{~mL})$ was added, and the mixture was extracted once with $\mathrm{CH}_{2} \mathrm{Cl}_{2}(200 \mathrm{~mL})$. The residue was roughly purified by column chromatography on silica gel (hexane/EtOAc $=9: 1)$ to obtain the impure 2-((1-Methylphenanthren-4yl)oxy)tetrahydro-2H-pyran (4.6 g) as a yellow oil. Following the General Procedure III, a mixture of impure 2-((1-methylphenanthren-4-yl)oxy)tetrahydro-2 $H$-pyran (4.6 g) and $2.8 \mathrm{M} n$-BuLi in hexane $(8.3 \mathrm{~mL}, 23 \mathrm{mmol})$ in anhydrous THF $(31 \mathrm{~mL})$ was stirred at 
room temperature for $45 \mathrm{~min}$ and stirred with $1.5 \mathrm{M} \mathrm{I}_{2}$ in THF $(22 \mathrm{~mL}, 31 \mathrm{mmol})$ at room temperature for $14 \mathrm{~h}$. The obtained crude product $(6.3 \mathrm{~g})$ and $6 \mathrm{~N} \mathrm{HCl}(4.2 \mathrm{~mL}, 25 \mathrm{mmol})$ in THF (42 mL) was stirred at room temperature for 2 h. $2 \mathrm{~N} \mathrm{NaOH}(13 \mathrm{~mL})$ was added, and the mixture was extracted once with $\mathrm{CH}_{2} \mathrm{Cl}_{2}(300 \mathrm{~mL})$. The crude product was purified by column chromatography on silica gel (hexane) to obtain the titled compound ( $2.1 \mathrm{~g}, 46 \%$ overall yield from 1-methylphenanthren-4-ol) as a pale yellow solid. Mp: 111-115 ${ }^{\circ} \mathrm{C} .{ }^{1} \mathrm{H}$ NMR (500 MHz, $\left.\mathrm{CDCl}_{3}\right) \delta: 2.64(3 \mathrm{H}, \mathrm{d}, J=0.5 \mathrm{~Hz}), 6.23(1 \mathrm{H}, \mathrm{s}), 7.61$ $(1 \mathrm{H}, \mathrm{ddd}, J=8.0,8.0,1.5 \mathrm{~Hz}), 7.68(1 \mathrm{H}, \mathrm{ddd}, J=8.0,8.0,1.5 \mathrm{~Hz}), 7.73(1 \mathrm{H}, \mathrm{d}, J=0.5$ $\mathrm{Hz}), 7.82(1 \mathrm{H}, \mathrm{d}, J=9.0 \mathrm{~Hz}), 7.85(1 \mathrm{H}, \mathrm{d}, J=9.0 \mathrm{~Hz}), 7.90(1 \mathrm{H}, \mathrm{dd}, J=8.0,1.5 \mathrm{~Hz})$, $9.68(1 \mathrm{H}$, brd, $J=8.0 \mathrm{~Hz}) .{ }^{13} \mathrm{C} \mathrm{NMR}\left(125 \mathrm{MHz}, \mathrm{CDCl}_{3}\right) \delta: 19.6,85.1,119.5,122.8$, 126.5, 126.9, 128.4, 128.6, 128.0, 129.1, 130.2, 132.5, 133.6, 135.8 151.5. IR (neat): 3448 $\mathrm{cm}^{-1}$. HRMS (MALDI) Calcd for $\mathrm{C}_{15} \mathrm{H}_{11} \mathrm{OI}[\mathrm{M}]^{+}: 333.9849$. Found: 333.9848 .

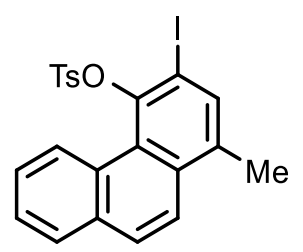

3-Iodo-1-methylphenanthren-4-yl 4-methylbenzenesulfonate (Table 2, entries 2 and 6): Following the General Procedure IV, a mixture of 3-iodo-1-methylphenanthren-4-ol (0.91 g, $2.7 \mathrm{mmol})$, ca. $60 \% \mathrm{NaH}$ in mineral oil (0.22 g, $5.5 \mathrm{mmol})$, and $p$-TsCl (0.65 g, $3.4 \mathrm{mmol})$ in anhydrous THF $(27 \mathrm{~mL}, 0.10 \mathrm{M})$ was stirred at $0{ }^{\circ} \mathrm{C}$ for $10 \mathrm{~min}$. The mixture was stirred at room temperature for $3 \mathrm{~h}$ and $\mathrm{H}_{2} \mathrm{O}(20 \mathrm{~mL})$ was added to the mixture at $0{ }^{\circ} \mathrm{C}$. The mixture was extracted with $\mathrm{Et}_{2} \mathrm{O}$. The residue was purified by silica column chromatography on silica gel $\left(\mathrm{CH}_{2} \mathrm{Cl}_{2}\right)$ to give the titled compound $(1.3 \mathrm{~g}, 96 \%)$ as a yellow solid. Mp: $160-163{ }^{\circ} \mathrm{C} .{ }^{1} \mathrm{H}$ NMR $\left(500 \mathrm{MHz}, \mathrm{CDCl}_{3}\right) \delta: 2.24(3 \mathrm{H}, \mathrm{s}), 2.65(3 \mathrm{H}$, s), $6.86(2 \mathrm{H}, \mathrm{d}, J=8.0 \mathrm{~Hz}), 7.25(1 \mathrm{H}, \mathrm{ddd}, J=8.0,8.0,1.0 \mathrm{~Hz}), 7.32(2 \mathrm{H}, \mathrm{d}, J=8.0$ Hz), $7.40(1 \mathrm{H}, \mathrm{ddd}, J=8.0,8.0,1.0 \mathrm{~Hz}), 7.64-7.68(2 \mathrm{H}, \mathrm{m}), 7.71(1 \mathrm{H}, \mathrm{d}, J=9.0 \mathrm{~Hz})$, $7.86(1 \mathrm{H}, \mathrm{s}), 8.85(1 \mathrm{H}, \mathrm{brd}, J=8.0 \mathrm{~Hz}) .{ }^{13} \mathrm{C} \mathrm{NMR}\left(125 \mathrm{MHz}, \mathrm{CDCl}_{3}\right) \delta: 19.4,21.5,91.6$, 121.8, 125.4, 126.1, 126.7, 127.5, 128.0, 128.2, 128.3, 128.6, 128.9, 132.0 132.7, 133.1, 135.1, 137.8, 145.1, 145.8. IR (neat): $2925 \mathrm{~cm}^{-1}$. HRMS (MALDI) Calcd for $\mathrm{C}_{22} \mathrm{H}_{17} \mathrm{O}_{3} \mathrm{NaSI}[\mathrm{M}+\mathrm{Na}]^{+}:$510.9835. Found: 510.9804 . 


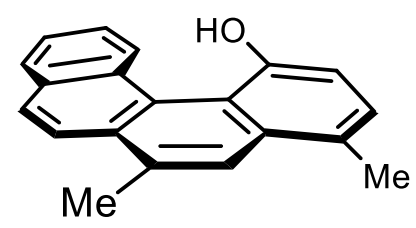

4,6-Dimethylbenzo[c]phenanthren-1-ol (Table 2, entry 2): (Table 2, entry 2): Following the General Procedure VI, a mixture of 3-iodo-1-methylphenanthren-4-yl 4methylbenzenesulfonate $(0.49 \mathrm{~g}, 1.0 \mathrm{mmol}), 2$-methylfuran $(0.45 \mathrm{~mL}, 5.0 \mathrm{mmol})$, and 1.1 $\mathrm{M} \mathrm{MeLi}$ in $\mathrm{Et}_{2} \mathrm{O}(1.8 \mathrm{~mL}, 2.0 \mathrm{mmol})$ was stirred in THF $(2.0 \mathrm{~mL}, 0.50 \mathrm{M})$ for $30 \mathrm{~min}$ at $-78{ }^{\circ} \mathrm{C}$. The mixture was stirred at room temperature for $11 \mathrm{~h}$. The residue was roughly purified by column chromatography on silica gel (hexane/ $\mathrm{CH}_{2} \mathrm{Cl}_{2}=1: 1$ ) to obtain a mixture of 4,6-dimethyl-1,4-dihydro-1,4-epoxybenzo[c]phenanthrene and 1,6-dimethyl1,4-dihydro-1,4-epoxybenzo[c]phenanthrene $(0.16 \mathrm{~g})$ as a brown oil. Following the General Procedure VI, a mixture of the obtained 1,4-epoxyphenanthrenes $(0.16 \mathrm{~g})$ and $\mathrm{BF}_{3} \cdot \mathrm{OEt}_{2}(0.16 \mathrm{~mL}, 1.2 \mathrm{mmol})$ in THF $(1.2 \mathrm{~mL})$ was reflux for $5 \mathrm{~h}$. A saturated $\mathrm{NaHCO}_{3}$ solution $(5 \mathrm{~mL})$ was added to the reaction. The residue was purified by column chromatography on silica gel (hexane/ $\mathrm{CH}_{2} \mathrm{Cl}_{2}=1: 1$ ) to obtain the titled compound (57 mg, 20\% in 2 steps) as a yellow solid. The structure was confirmed by NOESY. Mp: 80$82{ }^{\circ} \mathrm{C} .{ }^{1} \mathrm{H}$ NMR $\left(500 \mathrm{MHz}, \mathrm{CDCl}_{3}\right) \delta: 2.76(3 \mathrm{H}, \mathrm{s}), 2.83(3 \mathrm{H}, \mathrm{s}), 5.34(\mathrm{OH}, \mathrm{s}), 7.07(1 \mathrm{H}$, d, $J=7.5 \mathrm{~Hz}), 7.43(1 \mathrm{H}, \mathrm{d}, J=8.5 \mathrm{~Hz}), 7.62-7.69(2 \mathrm{H}, \mathrm{m}), 7.90(1 \mathrm{H}, \mathrm{s}), 8.02(1 \mathrm{H}, \mathrm{d}$, $J=9.0 \mathrm{~Hz}), 8.06(1 \mathrm{H}, \mathrm{d}, J=7.5 \mathrm{~Hz}), 8.10(1 \mathrm{H}, \mathrm{d}, J=9.0 \mathrm{~Hz}), 8.16(1 \mathrm{H}, \mathrm{d}, J=8.5 \mathrm{~Hz})$. ${ }^{13} \mathrm{C} \mathrm{NMR}\left(125 \mathrm{MHz}, \mathrm{CDCl}_{3}\right) \delta: 19.4,20.3,111.6,117.4,122.6,124.3,124.7,125.3,126.1$, $126.2,127.2,127.8,128.19,128.22,128.5,131.3,131.8,132.3,133.1,150.8$. IR (neat): $3445,1643 \mathrm{~cm}^{-1}$. HRMS (MALDI) Calcd for $\mathrm{C}_{20} \mathrm{H}_{16} \mathrm{O}[\mathrm{M}]^{+}:$272.1196. Found: 272.1192.

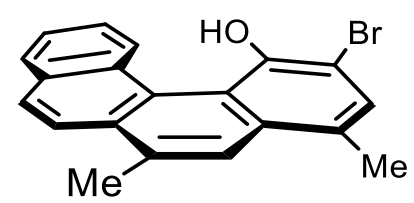

2-Bromo-4,6-dimethylbenzo[c]phenanthren-1-ol (Table 2, entry 2): An oven dried 20 $\mathrm{mL}$ flask was charged with 4,6-dimethylbenzo[c]phenanthren-1-ol $(0.10 \mathrm{~g}, 0.37 \mathrm{mmol})$ and tetrabutylammonium tribromide $(0.19 \mathrm{~g}, 0.39 \mathrm{mmol})$, then capped with an inlet adapter with 3-way stopcock and then evacuated and back-filled with argon. $\mathrm{CH}_{2} \mathrm{Cl}_{2}(3.7$ $\mathrm{mL}$ ) were added via a syringe, and the mixture was stirred at room temperature for $11 \mathrm{~h}$. 
The mixture was concentrated under reduced pressure. The residue was purified by column chromatography on silica gel (hexane/EtOAc $=5: 1$ ) to obtain the titled compound (0.13 g, quant) as a brown solid. Mp: $142-145{ }^{\circ} \mathrm{C} .{ }^{1} \mathrm{H} \mathrm{NMR}\left(500 \mathrm{MHz}, \mathrm{CDCl}_{3}\right) \delta: 2.73$ $(3 \mathrm{H}, \mathrm{s}), 2.81(3 \mathrm{H}, \mathrm{s}), 5.99(\mathrm{OH}, \mathrm{s}), 7.58-7.62(3 \mathrm{H}, \mathrm{m}), 7.81(1 \mathrm{H}, \mathrm{s}), 8.00-8.02(2 \mathrm{H}$, m), $8.05(1 \mathrm{H}, \mathrm{d}, J=9.0 \mathrm{~Hz}), 8.14-8.17(1 \mathrm{H}, \mathrm{m}) .{ }^{13} \mathrm{C} \mathrm{NMR}\left(125 \mathrm{MHz}, \mathrm{CDCl}_{3}\right) \delta: 19.1$, 20.3, 106.1, 118.3, 121.9, 123.6, 125.0, 125.6, 126.0, 126.8, 127.5, 127.9, 128.9, 130.0, 130.5, 131.5, 132.2, 132.7, 132.8, 147.2. IR (neat): 3649, $1508 \mathrm{~cm}^{-1}$. HRMS (MALDI) Calcd for $\mathrm{C}_{20} \mathrm{H}_{15} \mathrm{O}^{79} \mathrm{Br}[\mathrm{M}]^{+}:$350.0301. Found: 350.0305 .

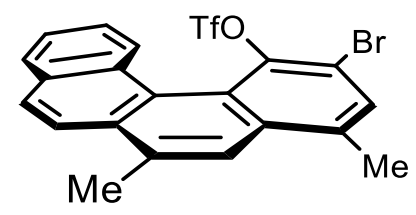

13b

2-Bromo-4,6-dimethylbenzo[c]phenanthren-1-yl trifluoromethanesulfonate (13b)

(Table 2, entry 2): Following the General Procedure IV, a mixture of 2-bromo-4,6dimethylbenzo[c]phenanthren-1-ol $(25 \mathrm{mg}, 0.071 \mathrm{mmol})$, pyridine $(0.010 \mathrm{~mL}, 0.13$ $\mathrm{mmol})$, and $\mathrm{Tf}_{2} \mathrm{O}(0.014 \mathrm{~mL}, 0.085 \mathrm{mmol})$ in anhydrous $\mathrm{CH}_{2} \mathrm{Cl}_{2}(0.71 \mathrm{~mL}, 0.10 \mathrm{M})$ was stirred at room temperature for $1 \mathrm{~h}$. A saturated $\mathrm{NaHCO}_{3}$ solution $(2 \mathrm{~mL})$ was added to the reaction solution. The mixture was extracted with $\mathrm{Et}_{2} \mathrm{O}$ and purified by flash column chromatography on silica gel (hexane/EtOAc $=20: 1$ ) to obtain the titled compound $\mathbf{1 3 b}$ (28 mg, 80\%) as a yellow solid. Mp: $157-159{ }^{\circ} \mathrm{C} .{ }^{1} \mathrm{H}$ NMR (500 MHz, $\left.\mathrm{CDCl}_{3}\right) \delta: 2.79$ (3 H, s), 2.83 (3H, s), 7.62-7.67 (2 H, m), $7.74(1 \mathrm{H}, \mathrm{s}), 7.80(1 \mathrm{H}, \mathrm{s}), 7.98-8.01(1 \mathrm{H}, \mathrm{m})$, $8.03(1 \mathrm{H}, \mathrm{d}, J=9.0 \mathrm{~Hz}), 8.06(1 \mathrm{H}, \mathrm{d}, J=9.0 \mathrm{~Hz}), 8.16(1 \mathrm{H}, \mathrm{dd}, J=7.0,2.0 \mathrm{~Hz}) .{ }^{13} \mathrm{C}$ NMR (125 MHz, $\left.\mathrm{CDCl}_{3}\right) \delta: 19.4,20.3,114.4,117.5$ (q, $\left.320 \mathrm{~Hz}\right), 121.3,122.2,122.6$, 124.6, 125.7, 126.5, 127.2, 129.2, 129.4, 131.2, 131.8, 132.3, 132.6, 134.5, 135.4, 141.1 . IR (neat): 1633, 1417, $1210 \mathrm{~cm}^{-1}$. HRMS (MALDI) Calcd for $\mathrm{C}_{21} \mathrm{H}_{14} \mathrm{O}_{3} \mathrm{~F}_{3} \mathrm{~S}^{81} \mathrm{Br}[\mathrm{M}]^{+}$: 483.9773. Found: 483.9765. 


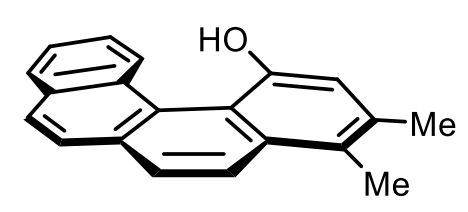

3,4-Dimethylbenzo[c]phenanthren-1-ol (Table 2, entry 3): Following the General Procedure VI, a mixture of 3-iodophenanthren-4-yl 4-methylbenzenesulfonate (0.95 g, $2.0 \mathrm{mmol}), 2,3$-dimethylfuran $(1.1 \mathrm{~mL}, 10 \mathrm{mmol}),{ }^{[19]}$ and $1.1 \mathrm{M} \mathrm{MeLi}$ in $\mathrm{Et}_{2} \mathrm{O}(3.7 \mathrm{~mL}$, $4.0 \mathrm{mmol})$ was stirred in anhydrous THF $(4.0 \mathrm{~mL}, 0.50 \mathrm{M})$ for $2 \mathrm{~h}$ at $-78{ }^{\circ} \mathrm{C}$. The mixture was stirred at room temperature for $11 \mathrm{~h}$. The residue was roughly purified by column chromatography on silica gel (hexane/ $\mathrm{CH}_{2} \mathrm{Cl}_{2}=1: 1$ ) to obtain a mixture of 3,4-dimethyl1,4-dihydro-1,4-epoxybenzo[c]phenanthrene and 1,2-dimethyl-1,4-dihydro-1,4epoxybenzo[ $c]$ phenanthrene $(0.32 \mathrm{~g})$ as a brown oil. Following the General Procedure III, a mixture of the obtained 1,4-epoxyphenanthrenes $(0.32 \mathrm{~g})$ and $\mathrm{BF}_{3} \cdot \mathrm{OEt}_{2}(0.29 \mathrm{~mL}, 2.3$ mmol) in THF (2.3 mL, $0.49 \mathrm{M})$ was refluxed for $13 \mathrm{~h}$. A saturated $\mathrm{NaHCO}_{3}$ solution (5 $\mathrm{mL}$ ) was added to the reaction and the reaction was extracted with EtOAc. The residue was purified by column chromatography on silica gel (hexane $/ \mathrm{CH}_{2} \mathrm{Cl}_{2}=1: 1$ ) to obtain the titled compound $(0.20 \mathrm{~g}, 35 \%$ in 2 steps $)$ as an orange oil. ${ }^{1} \mathrm{H} \mathrm{NMR}\left(300 \mathrm{MHz}, \mathrm{CDCl}_{3}\right)$ $\delta: 2.57(3 \mathrm{H}, \mathrm{s}), 2.67(3 \mathrm{H}, \mathrm{s}), 5.33(\mathrm{OH}, \mathrm{s}), 7.09(1 \mathrm{H}, \mathrm{s}), 7.59-7.70(2 \mathrm{H}, \mathrm{m}), 7.78(1 \mathrm{H}, \mathrm{d}$, $J=9.0 \mathrm{~Hz}), 7.88(1 \mathrm{H}, \mathrm{d}, J=8.5 \mathrm{~Hz}), 7.95(1 \mathrm{H}, \mathrm{d}, J=8.5 \mathrm{~Hz}), 8.04(1 \mathrm{H}, \mathrm{dd}, J=7.5$, $1.5 \mathrm{~Hz}), 8.13(1 \mathrm{H}, \mathrm{d}, J=9.0 \mathrm{~Hz}), 8.17(1 \mathrm{H}, \mathrm{d}, J=8.0 \mathrm{~Hz}) .{ }^{13} \mathrm{C} \mathrm{NMR}\left(125 \mathrm{MHz}, \mathrm{CDCl}_{3}\right)$ $\delta: 14.6,20.8,115.3,116.7,123.8,124.1,124.2,125.99,126.04,126.1,126.5,127.1,127.9$, 128.4, 130.8, 132.9, 133.8, 135.7, 150.1. IR (neat): 3563, $1422 \mathrm{~cm}^{-1}$. HRMS (MALDI) Calcd for $\mathrm{C}_{20} \mathrm{H}_{16} \mathrm{O}[\mathrm{M}]^{+}:$272.1196. Found: 272.1190 .

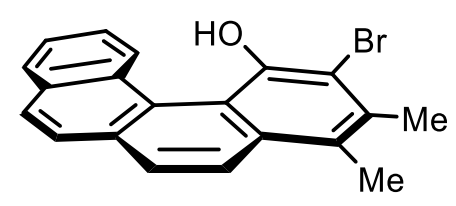

2-Bromo-3,4-dimethylbenzo[c]phenanthren-1-ol (Table 2, entry 3): An oven dried 20 $\mathrm{mL}$ flask was charged with 3,4-dimethylbenzo[c]phenanthren-1-ol (42 mg, $0.15 \mathrm{mmol}$ ) and pyridinium tribromide (54 mg, $0.17 \mathrm{mmol}$ ), then capped with an inlet adapter with 3 way stopcock and then evacuated and back-filled with argon. Anhydrous $\mathrm{CH}_{2} \mathrm{Cl}_{2}(1.5$ $\mathrm{mL}$ ) were added via a syringe, and the mixture was stirred at room temperature for $20 \mathrm{~h}$. A saturated $\mathrm{Na}_{2} \mathrm{SO}_{3}$ solution $(2 \mathrm{~mL})$ was added to the reaction, and the mixture was 
extracted once with $\mathrm{Et}_{2} \mathrm{O}(2 \mathrm{~mL})$. The organic layer was washed with $1 \mathrm{~N} \mathrm{HCl}(2 \mathrm{~mL})$ and brine $(2 \mathrm{~mL})$, dried over $\mathrm{MgSO}_{4}$, and concentrated under reduced pressure. The residue (54 mg) was used for the next reaction without further purification. ${ }^{1} \mathrm{H}$ NMR (400 MHz, $\left.\mathrm{CDCl}_{3}\right) \delta: 2.72(3 \mathrm{H}, \mathrm{s}), 2.75(3 \mathrm{H}, \mathrm{s}), 6.24(\mathrm{OH}, \mathrm{s}), 7.56-7.60(2 \mathrm{H}, \mathrm{m}), 7.79-7.83(2 \mathrm{H}$, m), $7.94(1 \mathrm{H}, \mathrm{d}, J=8.5 \mathrm{~Hz}), 7.97-7.99(1 \mathrm{H}, \mathrm{m}), 8.07$ (1 H, d, $J=8.5 \mathrm{~Hz}), 8.17-8.21$ (1 $\mathrm{H}, \mathrm{m}) .{ }^{13} \mathrm{C} \mathrm{NMR}\left(125 \mathrm{MHz}, \mathrm{CDCl}_{3}\right) \delta: 16.2,21.1,112.4,117.3,123.3,124.7,124.8$, $125.3,125.7,125.8,127.0,127.6,127.9,129.2$, 130.1, 131.1, 132.6, 133.6, 146.9. IR (neat): 3688, $1422 \mathrm{~cm}^{-1}$. HRMS (MALDI) Calcd for $\mathrm{C}_{20} \mathrm{H}_{15} \mathrm{O}^{29} \mathrm{Br}[\mathrm{M}]^{+}: 350.0301$. Found: 350.0297.

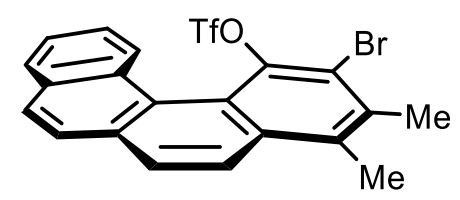

$13 c$

\section{2-Bromo-3,4-dimethylbenzo[c]phenanthren-1-yl trifluoromethanesulfonate (13c)}

(Table 2, entry 3): Following the General Procedure IV, a mixture of 2-bromo-3,4dimethylbenzo[c]phenanthren-1-ol (54 mg), pyridine $(0.030 \mathrm{~mL}, 0.37 \mathrm{mmol})$, and $\mathrm{Tf}_{2} \mathrm{O}$ $(0.040 \mathrm{~mL}, 0.25 \mathrm{mmol})$ in anhydrous $\mathrm{CH}_{2} \mathrm{Cl}_{2}(0.10 \mathrm{M}, 1.5 \mathrm{~mL})$ was stirred at $0{ }^{\circ} \mathrm{C}$ for 10 min. The mixture was stirred at room temperature for $30 \mathrm{~min}$ and $1 \mathrm{~N} \mathrm{HCl}(2 \mathrm{~mL})$ was added to the mixture. The mixture was extracted with $\mathrm{Et}_{2} \mathrm{O}$. The crude mixture was purified by column chromatography on silica gel (hexane/ $\mathrm{CH}_{2} \mathrm{Cl}_{2}=5: 1$ ) to obtain the titled compound 13c (34 mg, 46\% in 2 steps) as a colorless solid. Mp: $160-163{ }^{\circ} \mathrm{C} .{ }^{1} \mathrm{H}$ NMR (300 MHz, $\left.\mathrm{CDCl}_{3}\right) \delta: 2.78(3 \mathrm{H}, \mathrm{s}), 2.83(3 \mathrm{H}, \mathrm{s}), 7.59-7.68(2 \mathrm{H}, \mathrm{m}), 7.83(1 \mathrm{H}, \mathrm{d}$, $J=8.5 \mathrm{~Hz}), 7.88(1 \mathrm{H}, \mathrm{d}, J=9.0 \mathrm{~Hz}), 7.97-8.02(2 \mathrm{H}, \mathrm{m}), 8.06(1 \mathrm{H}, \mathrm{d}, J=9.0 \mathrm{~Hz}), 8.16$ $(1 \mathrm{H}, \mathrm{d}, J=7.5 \mathrm{~Hz}) .{ }^{13} \mathrm{C} \mathrm{NMR}\left(125 \mathrm{MHz}, \mathrm{CDCl}_{3}\right) \delta: 16.8,21.3,117.4(\mathrm{q}, 321 \mathrm{~Hz}), 120.4$, $121.1,122.5,124.0,125.2,125.7,126.3,127.5,128.1,128.8,129.1,129.4,131.4,132.6$, 132.7, 133.6, 134.9, 141.1. IR (neat): 1541, 1417, $1268 \mathrm{~cm}^{-1}$. HRMS (MALDI) Calcd for $\mathrm{C}_{21} \mathrm{H}_{14} \mathrm{O}_{3} \mathrm{~F}_{3} \mathrm{~S}^{81} \mathrm{Br}[\mathrm{M}]^{+}:$483.9773. Found: 483.9782 . 


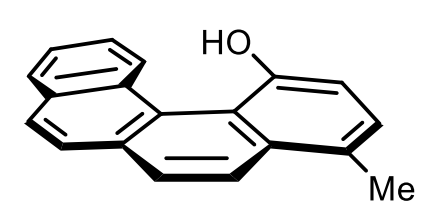

4-Methylbenzo[c]phenanthren-1-ol (Table 2, entry 4): Following the General Procedure VI, a mixture of 3-iodophenanthren-4-yl 4-methylbenzenesulfonate (1.4 g, 3.0 mmol), 2-methylfuran (1.3 mL, $15 \mathrm{mmol})$, and 1.1 M MeLi in $\mathrm{Et}_{2} \mathrm{O}$ (5.5 mL, $6.0 \mathrm{mmol}$ ) was stirred in THF $(0.50 \mathrm{M}, 6.0 \mathrm{~mL})$ for $2 \mathrm{~h}$ at $-78{ }^{\circ} \mathrm{C}$. The mixture was stirred at room temperature for $18 \mathrm{~h}$. The residue was roughly purified by column chromatography on silica gel (hexane/ $\mathrm{CH}_{2} \mathrm{Cl}_{2}=1: 1$ ) to obtain a mixture of 4-methyl-1,4-dihydro-1,4epoxybenzo[c]phenanthrene and 1-methyl-1,4-dihydro-1,4-epoxybenzo[c]phenanthrene $(0.58 \mathrm{~g})$ as a brown oil. Following the General Procedure VI, a mixture of the obtained regioisomers $(0.58 \mathrm{~g}), \mathrm{BF}_{3} \cdot \mathrm{OEt}_{2}(0.58 \mathrm{~mL}, 4.5 \mathrm{mmol})$ in $\mathrm{THF}(4.5 \mathrm{~mL}, 0.49 \mathrm{M})$ was refluxed for $2 \mathrm{~h}$. A saturated $\mathrm{NaHCO}_{3}$ solution $(5 \mathrm{~mL})$ was added to the reaction solution. The residue was purified by column chromatography on silica gel (hexane $/ \mathrm{CH}_{2} \mathrm{Cl}_{2}=1: 1$ ) to obtain the titled compound $(0.21 \mathrm{~g}, 27 \%$ in 2 steps) as a red-orange solid. Mp: 107$110{ }^{\circ} \mathrm{C} .{ }^{1} \mathrm{H}$ NMR $\left(500 \mathrm{MHz}, \mathrm{CDCl}_{3}\right) \delta: 2.78(3 \mathrm{H}, \mathrm{s}), 5.39(\mathrm{OH}, \mathrm{s}), 7.14(1 \mathrm{H}, \mathrm{d}, J=7.5$ $\mathrm{Hz}), 7.47(1 \mathrm{H}, \mathrm{d}, J=7.5 \mathrm{~Hz}), 7.64(1 \mathrm{H}, \mathrm{ddd}, J=7.5,7.5,1.0 \mathrm{~Hz}), 7.69(1 \mathrm{H}, \mathrm{ddd}, J=$ 7.5, 7.5, 1.0 Hz), $7.82(1 \mathrm{H}, \mathrm{d}, J=9.0 \mathrm{~Hz}), 7.90(1 \mathrm{H}, \mathrm{d}, J=8.5 \mathrm{~Hz}), 7.98(1 \mathrm{H}, \mathrm{d}, J=8.5$ $\mathrm{Hz}), 8.06(1 \mathrm{H}, \mathrm{dd}, J=7.5,1.0 \mathrm{~Hz}), 8.08(1 \mathrm{H}, \mathrm{d}, J=9.0 \mathrm{~Hz}), 8.18(1 \mathrm{H}, \mathrm{brd}, J=7.5 \mathrm{~Hz})$. ${ }^{13} \mathrm{C} \mathrm{NMR}\left(125 \mathrm{MHz}, \mathrm{CDCl}_{3}\right) \delta: 19.4,112.4,118.2,124.1,124.2,126.02,126.08,126.13$, 126.5, 127.4, 127.8, 127.9, 128.4, 131.4, 132.8, 133.4, 150.9. IR (neat): 3522, $1659 \mathrm{~cm}^{-}$ 1. HRMS (MALDI) Calcd for $\mathrm{C}_{19} \mathrm{H}_{14} \mathrm{O}[\mathrm{M}]^{+}:$258.1039. Found: 258.1040.

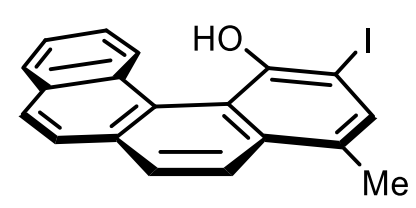

Iodo-4-methylbenzo[c]phenanthren-1-ol (Table 2, entry 4): $15 \mathrm{~mL}$ flask charged with 4-methylbenzo[c]phenanthren-1-ol $(0.20 \mathrm{~g}, 0.78 \mathrm{mmol}), \mathrm{CH}_{2} \mathrm{Cl}_{2}(7.0 \mathrm{~mL}), \mathrm{TsOH} \cdot \mathrm{H}_{2} \mathrm{O}$ $(15 \mathrm{mg}, 0.078 \mathrm{mmol})$ and NIS (0.19 g, $0.86 \mathrm{mmol})$. The mixture was capped and stirred at room temperature for $8 \mathrm{~h}$. A saturated $\mathrm{Na}_{2} \mathrm{~S}_{2} \mathrm{O}_{3}$ solution $(10 \mathrm{~mL})$ was added to the reaction solution, and the mixture was extracted with $\mathrm{CH}_{2} \mathrm{Cl}_{2}(20 \mathrm{~mL})$. The organic phase was washed with brine $(8 \mathrm{~mL})$, dried over $\mathrm{Na}_{2} \mathrm{SO}_{4}$, and concentrated under reduced 
pressure. The residue was purified by column chromatography on silica gel (hexane) as a white solid (0.19 g, 62\%). Mp: $122-125{ }^{\circ} \mathrm{C} .{ }^{1} \mathrm{H} \mathrm{NMR}\left(500 \mathrm{MHz}, \mathrm{CDCl}_{3}\right) \delta: 2.73(3 \mathrm{H}, \mathrm{s})$, $5.97(1 \mathrm{H}, \mathrm{s}), 7.61-7.68$ (2 H, m), 7.97 (1 H, d, $J=8.0 \mathrm{~Hz}), 7.99-7.86$ (2 H, m), 7.96$8.03(3 \mathrm{H}, \mathrm{m}), 8.15(1 \mathrm{H}, \mathrm{d}, J=8.0 \mathrm{~Hz}) .{ }^{13} \mathrm{C} \mathrm{NMR}\left(125 \mathrm{MHz}, \mathrm{CDCl}_{3}\right) \delta: 19.1,82.1,118.3$, $123.8,124.8,125.9,126.26,126.34,127.2$, 128.1, 128.2, 128.3, 128.6, 129.2, 131.8, 133.0, 133.9, 136.6, 150.1. IR (neat): $3516 \mathrm{~cm}^{-1}$. HRMS (MALDI) Calcd for $\mathrm{C}_{19} \mathrm{H}_{13} \mathrm{OI}$ $[\mathrm{M}]^{+}:$384.0006. Found: 383.9993.

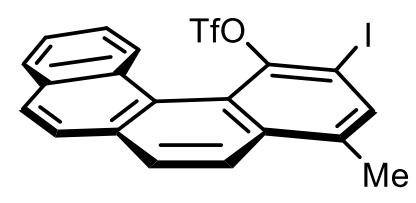

13d

2-Bromo-4-methylbenzo[c]phenanthren-1-yl trifluoromethanesulfonate

(13d)

(Table 2, entry 4): Following the General Procedure IV, a mixture of iodo-4methylbenzo[c]phenanthren-1-ol $(0.19 \mathrm{~g}, 0.49 \mathrm{mmol})$, ca. $60 \% \mathrm{NaH}$ in mineral oil $(0.20$ $\mathrm{g}, 4.9 \mathrm{mmol})$, and $\mathrm{Tf}_{2} \mathrm{O}(0.25 \mathrm{~mL}, 1.5 \mathrm{mmol})$ in anhydrous $\mathrm{CH}_{2} \mathrm{Cl}_{2}(4.9 \mathrm{~mL})$ was stirred at room temperature for $22 \mathrm{~h} . \mathrm{H}_{2} \mathrm{O}(10 \mathrm{~mL})$ was added to the mixture at $0{ }^{\circ} \mathrm{C}$. The mixture was extracted with $\mathrm{CH}_{2} \mathrm{Cl}_{2}$ and purified by flash column chromatography on silica gel (hexane/EtOAc $=5: 1)$ to give the titled compound $(0.18 \mathrm{~g}, 70 \%)$ as a yellow solid. Mp: 126-128 ${ }^{\circ} \mathrm{C} .{ }^{1} \mathrm{H}$ NMR $\left(500 \mathrm{MHz}, \mathrm{CDCl}_{3}\right) \delta: 2.78(3 \mathrm{H}, \mathrm{s}), 7.63(1 \mathrm{H}, \mathrm{ddd}, J=8.0,8.0$, $1.5 \mathrm{~Hz}), 7.67(1 \mathrm{H}, \mathrm{ddd}, J=8.0,8.0,1.5 \mathrm{~Hz}), 7.83(1 \mathrm{H}, \mathrm{d}, J=8.5 \mathrm{~Hz}), 7.91(1 \mathrm{H}, \mathrm{d}, J=$ $8.5 \mathrm{~Hz}), 7.96-8.00(3 \mathrm{H}, \mathrm{m}), 8.02(1 \mathrm{H}, \mathrm{d}, J=8.5 \mathrm{~Hz}), 8.16(1 \mathrm{H}, \mathrm{d}, J=8.0 \mathrm{~Hz}) .{ }^{13} \mathrm{C} \mathrm{NMR}$ $\left(125 \mathrm{MHz} \mathrm{CDCl}_{3}\right) \delta: 19.3,89.2,117.6$ (q, $\left.321 \mathrm{~Hz}\right), 122.4,122.7,124.1,125.3,125.8$, $126.5,127.5,128.5,128.8,129.3,129.4,131.8,132.8,133.7,136.2,137.1,144.3 .{ }^{19} \mathrm{~F}$ NMR (470 MHz, $\left.\mathrm{CDCl}_{3}\right) \delta:-74.88$. IR (neat): $3051 \mathrm{~cm}^{-1}$. HRMS (EI) Calcd for $\mathrm{C}_{20} \mathrm{H}_{12} \mathrm{O}_{3} \mathrm{~F}_{3} \mathrm{SI}[\mathrm{M}]^{+}:$515.9498. Found: 515.9506. 


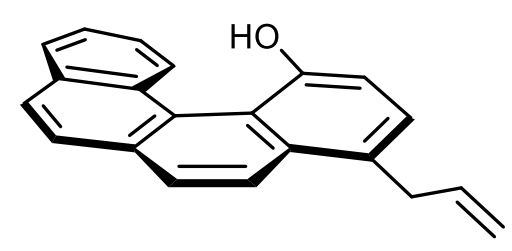

4-Allylbenzo[c]phenanthren-1-ol (Table 2, entry 5): Following the General Procedure VI, a mixture of 3-iodophenanthren-4-yl 4-methylbenzenesulfonate (3.3 g, $7.0 \mathrm{mmol})$, 2allylfuran $^{[11]}$ (2-allylfuran/hexane =6:1) $(4.2 \mathrm{~g}, 35 \mathrm{mmol})$, and 1.1 M MeLi in $\mathrm{Et}_{2} \mathrm{O}(13$ $\mathrm{mL}, 14 \mathrm{mmol})$ was stirred in anhydrous THF $(0.35 \mathrm{M}, 20 \mathrm{~mL})$ for $1 \mathrm{~h}$ at $-78^{\circ} \mathrm{C}$. The mixture was stirred at room temperature for $17 \mathrm{~h}$. The residue was roughly purified by column chromatography on silica gel (hexane $/ \mathrm{CH}_{2} \mathrm{Cl}_{2}=1: 1$ ) to obtain a mixture of the 4allyl-1,4-dihydro-1,4-epoxybenzo[c]phenanthrene and 1-allyl-1,4-dihydro-1,4epoxybenzo[c]phenanthrene (1.2 g) as a brown oil. Following the General Procedure VI, a mixture of the obtained regioisomers $(1.2 \mathrm{~g}), \mathrm{BF}_{3} \cdot \mathrm{OEt}_{2}(1.1 \mathrm{~mL}, 8.7 \mathrm{mmol})$ in THF (8.7 $\mathrm{mL}, 0.49 \mathrm{M}$ ) was stirred under reflux conditions for $14 \mathrm{~h}$. A saturated $\mathrm{NaHCO}_{3}$ solution $(30 \mathrm{~mL})$ was added to the reaction solution. The residue was purified by column chromatography on silica gel (hexane/ $\left.\mathrm{CH}_{2} \mathrm{Cl}_{2}=1: 1\right)$ to obtain the titled compound $(0.50$ g, $24 \%$ in 2 steps) as a red-orange oil. ${ }^{1} \mathrm{H}$ NMR $\left(500 \mathrm{MHz}, \mathrm{CDCl}_{3}\right) \delta: 3.94(2 \mathrm{H}, \mathrm{d}, J=$ $6.0 \mathrm{~Hz}), 5.16-5.21(2 \mathrm{H}, \mathrm{m}) 5.55(1 \mathrm{H}, \mathrm{s}), 6.19-6.26(1 \mathrm{H}, \mathrm{m}) 7.22(1 \mathrm{H}, \mathrm{d}, J=8.0 \mathrm{~Hz})$, $7.51(1 \mathrm{H}, \mathrm{d}, J=8.0 \mathrm{~Hz}), 7.64(1 \mathrm{H}, \mathrm{dd}, J=7.5,7.5 \mathrm{~Hz}), 7.69(1 \mathrm{H}, \mathrm{dd}, J=7.5,7.5 \mathrm{~Hz})$, $7.78(1 \mathrm{H}, \mathrm{d}, J=9.0 \mathrm{~Hz}), 7.87(1 \mathrm{H}, \mathrm{d}, J=8.5 \mathrm{~Hz}), 7.95(1 \mathrm{H}, \mathrm{d}, J=8.5 \mathrm{~Hz}), 8.04(1 \mathrm{H}$, $\mathrm{d}, J=8.0 \mathrm{~Hz}), 8.10(1 \mathrm{H}, \mathrm{d}, J=9.0 \mathrm{~Hz}), 8.23(1 \mathrm{H}, \mathrm{d}, J=8.0 \mathrm{~Hz}) .{ }^{13} \mathrm{C} \mathrm{NMR}(125 \mathrm{MHz}$, $\left.\mathrm{CDCl}_{3}\right) \delta: 37.4,112.7,116.1,118.5,124.1,124.3,126.17,126.21,126.5,127.6,127.9$, 128.08, 128.12, 128.4, 128.5, 131.4, 132.9, 133.1, 137.7, 151.4. IR (neat): $3567 \mathrm{~cm}^{-1}$. HRMS (MALDI) Calcd for $\mathrm{C}_{21} \mathrm{H}_{16} \mathrm{O}[\mathrm{M}]^{+}:$284.1196. Found: 284.1200.

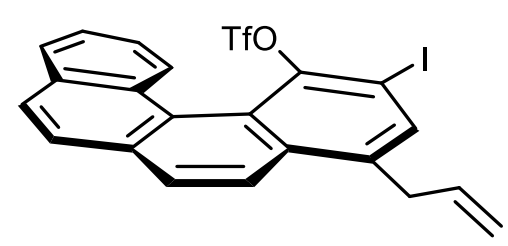

$13 e$

4-Allyl-2-iodobenzo[c]phenanthren-1-yl trifluoromethanesulfonate (13e) (Table 2, entry 5): (Table 2, entry 5): $15 \mathrm{~mL}$ flask charged with 4-allylbenzo[c]phenanthren-1-ol (0.37 g, $1.3 \mathrm{mmol}), \mathrm{CH}_{2} \mathrm{Cl}_{2}(13 \mathrm{~mL}), \mathrm{TsOH} \cdot \mathrm{H}_{2} \mathrm{O}(25 \mathrm{mg}, 0.13 \mathrm{mmol})$ and NIS (0.32 g, 
$1.4 \mathrm{mmol}$ ). The mixture was capped and stirred at room temperature for $6 \mathrm{~h}$. A saturated $\mathrm{Na}_{2} \mathrm{~S}_{2} \mathrm{O}_{3}$ solution $(10 \mathrm{~mL})$ was added to the reaction solution, and the mixture was extracted with $\mathrm{CH}_{2} \mathrm{Cl}_{2}(20 \mathrm{~mL})$. The organic layer was washed with brine $(8 \mathrm{~mL})$, dried over $\mathrm{Na}_{2} \mathrm{SO}_{4}$, and concentrated under reduced pressure. The residue was purified by column chromatography on silica gel (hexane/ $\mathrm{CH}_{2} \mathrm{Cl}_{2}=1: 1$ ) to afford 4-allyl-2iodobenzo[c]phenanthren-1-ol (89 mg) as a green solid. Following the General Procedure IV, a mixture of 4-allyl-2-iodobenzo[c]phenanthren-1-ol $(89 \mathrm{mg})$, ca. $60 \% \mathrm{NaH}$ in mineral oil ( $86 \mathrm{mg}, 2.2 \mathrm{mmol})$, and $\mathrm{Tf}_{2} \mathrm{O}(0.14 \mathrm{~mL}, 0.87 \mathrm{mmol})$ in anhydrous $\mathrm{CH}_{2} \mathrm{Cl}_{2}(2.2$ $\mathrm{mL}, 0.10 \mathrm{M}$ ) was stirred at $0{ }^{\circ} \mathrm{C}$ for $1 \mathrm{~h}$. The mixture was stirred at room temperature for $3 \mathrm{~h}$ and $\mathrm{H}_{2} \mathrm{O}(5 \mathrm{~mL})$ was added to the mixture at $0{ }^{\circ} \mathrm{C}$. The residue was purified by column chromatography on silica gel (hexane/EtOAc $=5: 1)$ to give the titled compound $13 \mathbf{e}(60$ mg, $8 \%$ in 2 steps) as a yellow oil. ${ }^{1} \mathrm{H}$ NMR $\left(500 \mathrm{MHz}, \mathrm{CDCl}_{3}\right) \delta: 3.87-3.96(2 \mathrm{H}, \mathrm{m})$, 5.15-5.25 (2 H, m), 6.09-6.17 (1 H, m), $7.63(1 \mathrm{H}, \mathrm{ddd}, J=7.5,7.5,1.5 \mathrm{~Hz}), 7.67(1 \mathrm{H}$, ddd, $J=7.5,7.5,1.5 \mathrm{~Hz}), 7.83(1 \mathrm{H}, \mathrm{d}, J=8.5 \mathrm{~Hz}), 7.90(1 \mathrm{H}, \mathrm{d}, J=9.0 \mathrm{~Hz}), 7.98-8.04$ $(4 \mathrm{H}, \mathrm{m}), 8.16(1 \mathrm{H}$, brd, $J=7.5 \mathrm{~Hz}) .{ }^{13} \mathrm{C} \mathrm{NMR}\left(125 \mathrm{MHz}, \mathrm{CDCl}_{3}\right) \delta: 37.0,89.5,117.7$ (q, $320 \mathrm{~Hz}), 117.9,122.4,123.1,124.4,125.4,126.0,126.7,127.7,128.7,128.9,129.5$, $129.7,131.9,132.9,133.4,135.6,137.0,138.1,144.8 .{ }^{19} \mathrm{~F}$ NMR $\left(470 \mathrm{MHz}, \mathrm{CDCl}_{3}\right) \delta$ :74.85. IR (neat): $3052 \mathrm{~cm}^{-1}$. HRMS (EI) Calcd for $\mathrm{C}_{22} \mathrm{H}_{14} \mathrm{~F}_{3} \mathrm{O}_{3} \mathrm{SI}[\mathrm{M}]^{+}: 541.9655$. Found: 541.9657.

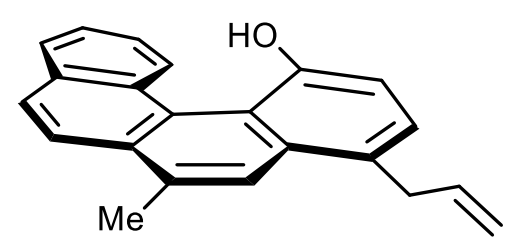

4-Allyl-6-methylbenzo[c]phenanthren-1-ol (Table 2, entry 6): Following the General Procedure VI, a mixture of 3-iodo-1-methylphenanthren-4-yl 4-methylbenzenesulfonate (3.3 g, $6.7 \mathrm{mmol}), 2$-allylfuran ${ }^{[11]}$ (2-allylfuran/hexane =6:1) $(4.0 \mathrm{~g}, 33 \mathrm{mmol})$, and 1.1 $\mathrm{M} \mathrm{MeLi}$ in $\mathrm{Et}_{2} \mathrm{O}(12 \mathrm{~mL}, 13 \mathrm{mmol})$ was stirred in THF $(19 \mathrm{~mL}, 0.35 \mathrm{M})$ for $1 \mathrm{~h}$ at $-78{ }^{\circ} \mathrm{C}$. The mixture was stirred at room temperature for $4 \mathrm{~h}$. The residue was roughly purified by column chromatography on silica gel (hexane/ $\mathrm{CH}_{2} \mathrm{Cl}_{2}=1: 1$ ) to obtain a mixture of 4allyl-6-methyl-1,4-dihydro-1,4-epoxybenzo[c]phenanthrene and 1-allyl-6-methyl-1,4dihydro-1,4-epoxybenzo[c]phenanthrene $(1.4 \mathrm{~g})$ as a brown oil. Following the General 
Procedure VI, a mixture of the obtained regioisomers $(1.4 \mathrm{~g}), \mathrm{BF}_{3} \cdot \mathrm{OEt}_{2}(1.3 \mathrm{~mL}, 9.6$ mmol) was stirred in THF $(9.6 \mathrm{~mL}, 0.50 \mathrm{M})$ was stirred under reflux conditions for $4 \mathrm{~h}$. A saturated $\mathrm{NaHCO}_{3}$ solution $(5 \mathrm{~mL})$ was added to the reaction solution. The residue was purified by column chromatography on silica gel (hexane/ $\mathrm{CH}_{2} \mathrm{Cl}_{2}=1: 1$ ) to obtain the mixture including titled compound. And next, the mixture was purified by GPC (only $\left.\mathrm{CHCl}_{3}\right)$ to obtain the titled compound $(0.25 \mathrm{~g}, 12 \%$ in 2 steps $)$ as a yellow oil. The structure was confirmed by NOESY. ${ }^{1} \mathrm{H}$ NMR $\left(400 \mathrm{MHz}, \mathrm{CDCl}_{3}\right) \delta: 2.81(3 \mathrm{H}, \mathrm{s}), 3.89-$ $3.90(2 \mathrm{H}, \mathrm{m}), 5.10-5.15(2 \mathrm{H}, \mathrm{m}), 5.39(\mathrm{OH}, \mathrm{brs}), 6.14-6.24(1 \mathrm{H}, \mathrm{m}), 7.11(1 \mathrm{H}, \mathrm{d}, J=$ $8.0 \mathrm{~Hz}), 7.45(1 \mathrm{H}, \mathrm{d}, J=8.0 \mathrm{~Hz}), 7.63(1 \mathrm{H}, \mathrm{ddd}, J=8.0,8.0,1.0 \mathrm{~Hz}), 7.68(1 \mathrm{H}, \mathrm{ddd}, J$ $=8.0,8.0,1.0 \mathrm{~Hz}), 7.91(1 \mathrm{H}, \mathrm{s}), 8.01(1 \mathrm{H}, \mathrm{d}, J=8.5 \mathrm{~Hz}), 8.06(1 \mathrm{H}, \mathrm{dd}, J=8.0,1.0 \mathrm{~Hz})$, $8.09(1 \mathrm{H}, \mathrm{d}, J=8.5 \mathrm{~Hz}), 8.16(1 \mathrm{H}, \mathrm{d}, J=8.0 \mathrm{~Hz}) .{ }^{13} \mathrm{C} \mathrm{NMR}\left(100 \mathrm{MHz}, \mathrm{CDCl}_{3}\right) \delta: 20.5$, $37.4,111.9,116.1,117.7,122.7,124.3,124.9$, 126.3 , 126.4, 127.37, 127.42, 127.9, 128.3, $128.4,128.5,131.4,132.1,132.5,132.9,137.8,151.4$. IR (neat): $3525 \mathrm{~cm}^{-1}$. HRMS (MALDI) Calcd for $\mathrm{C}_{22} \mathrm{H}_{18} \mathrm{O}[\mathrm{M}]^{+}:$298.1352. Found: 298.1352 .

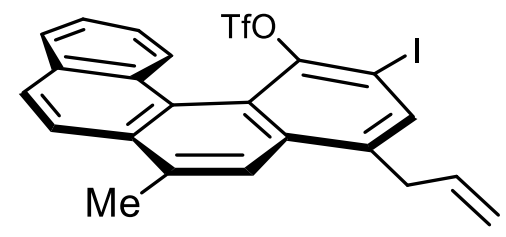

$13 \mathbf{e}$

\section{4-Allyl-2-iodo-6-methylbenzo[c]phenanthren-1-yl trifluoromethanesulfonate (13e)}

(Table 2, entry 6): $15 \mathrm{~mL}$ flask was charged with 4-allyl-6-methylbenzo[c]phenanthren1-ol (0.46 g, $1.5 \mathrm{mmol}), \mathrm{CH}_{2} \mathrm{Cl}_{2}(13 \mathrm{~mL}), \mathrm{TsOH} \cdot \mathrm{H}_{2} \mathrm{O}(29 \mathrm{mg}, 0.15 \mathrm{mmol})$ and NIS (0.38 $\mathrm{g}, 1.7 \mathrm{mmol}$ ). The mixture was capped and stirred at room temperature for $4 \mathrm{~h}$. A saturated $\mathrm{Na}_{2} \mathrm{~S}_{2} \mathrm{O}_{3}$ solution $(10 \mathrm{~mL})$ was added to the reaction solution, and the mixture was extracted with $\mathrm{CH}_{2} \mathrm{Cl}_{2}(20 \mathrm{~mL})$. The organic layer was washed with brine $(8 \mathrm{~mL})$, dried over $\mathrm{Na}_{2} \mathrm{SO}_{4}$, and concentrated under reduced pressure. The residue was purified by column chromatography on silica gel (hexane/ $\mathrm{CH}_{2} \mathrm{Cl}_{2}=1: 1$ ) to afford 4-allyl-2-iodo-6methylbenzo[c]phenanthren-1-ol $(51 \mathrm{mg})$ as a green solid. Following the General Procedure IV, a mixture of the obtained phenanthrenol $(51 \mathrm{mg})$, ca. $60 \% \mathrm{NaH}$ in mineral oil (48 mg, $1.2 \mathrm{mmol})$, and $\mathrm{Tf}_{2} \mathrm{O}(0.078 \mathrm{~mL}, 0.48 \mathrm{mmol})$ in anhydrous $\mathrm{CH}_{2} \mathrm{Cl}_{2}(1.2 \mathrm{~mL}$, $0.10 \mathrm{M}$ ) was stirred at $0{ }^{\circ} \mathrm{C}$ for $1 \mathrm{~h}$. The mixture was stirred at room temperature for $2 \mathrm{~h}$ 
and $\mathrm{H}_{2} \mathrm{O}$ was added to the mixture at $0{ }^{\circ} \mathrm{C}$. The residue was purified by column chromatography on silica gel (hexane/EtOAc $=5: 1$ ) to give the titled compound d 13e $\left(0.042 \mathrm{~g}, 5 \%\right.$ in 2 steps) as a yellow oil. ${ }^{1} \mathrm{H}$ NMR $\left(500 \mathrm{MHz}, \mathrm{CDCl}_{3}\right) \delta: 2.82(3 \mathrm{H}, \mathrm{d}, J=$ $1.0 \mathrm{~Hz}), 3.88-3.95(2 \mathrm{H}, \mathrm{m}), 5.15-5.24(2 \mathrm{H}, \mathrm{m}), 6.10-6.18(1 \mathrm{H}, \mathrm{m}), 7.62(1 \mathrm{H}, \mathrm{ddd}, J=$ 7.0, 7.0, $1.5 \mathrm{~Hz}), 7.65(1 \mathrm{H}, \mathrm{ddd}, J=7.0,7.0,1.5 \mathrm{~Hz}), 7.82(1 \mathrm{H}, \mathrm{d}, J=1.0 \mathrm{~Hz}), 7.93(1$ $\mathrm{H}, \mathrm{s}), 7.99(1 \mathrm{H}, \mathrm{dd}, J=7.0,1.5 \mathrm{~Hz}), 8.02(1 \mathrm{H}, \mathrm{d}, J=8.5 \mathrm{~Hz}), 8.06(1 \mathrm{H}, \mathrm{d}, J=8.5 \mathrm{~Hz})$, $8.13(1 \mathrm{H}, \mathrm{dd}, J=7.0,1.5 \mathrm{~Hz}) .{ }^{13} \mathrm{C}$ NMR $\left(125 \mathrm{MHz}, \mathrm{CDCl}_{3}\right) \delta: 20.6,36.9,88.2,117.7$ (q, $320 \mathrm{~Hz}), 117.8,121.5,122.3,122.5,124.8,126.0,126.6,127.4,129.2,129.4,129.5,131.7$, 132.4, 133.1, 135.0, 135.7, 137.0, 137.3, 144.7. $\left.{ }^{19} \mathrm{~F} \mathrm{NMR} \mathrm{(470} \mathrm{MHz,} \mathrm{CDCl}_{3}\right)$ 8: -74.93. IR (neat): $3072 \mathrm{~cm}^{-1}$. HRMS (EI) Calcd for $\mathrm{C}_{23} \mathrm{H}_{16} \mathrm{~F}_{3} \mathrm{O}_{3} \mathrm{SI}[\mathrm{M}]^{+}:$555.9811. Found: 555.9815 . 


\section{Computational details:}

All calculations except for the energy decomposition analysis (EDA) were carried out with Gaussian $16^{[5]}$ or ORCA. ${ }^{[25]}$ The EDA ${ }^{[26]}$ was performed with the GAMESS. ${ }^{[9]}$ The EDA calculations were performed with two fragments obtained by splitting the two $\mathrm{sp}^{2}$ bonds constructing cyclobutadiene rings at 10a, following splitting rules of the Fragment Molecular Orbital (FMO) method. ${ }^{[27]}$ The electronic energies in Figure 1a were evaluated by DLPNO-CCSD(T)/def2-TZVP level at the optimized structures obtained by B3LYPD3(BJ)/PCM/def2-TZVP level, and the Gibbs free energy correction terms were estimated by the latter level for simplicity. The electronic energies in Figure $1 \mathrm{~b}$ were calculated at MP2/cc-pVDZ level for the optimized structures obtained by B3LYPD3(BJ)/PCM/def2-TZVP level. Geometry optimizations for NCI plots ${ }^{[28]}$ in Figure 2 were carried out with B3LYP-D3(BJ)/PCM/def2-TZVP. The solvent effect (solvent = THF) was calculated by using the Conductor-like Polarizable Continuum Model (PCM) solvation model. ${ }^{[29]}$ Computed structures are illustrated using CYLview. ${ }^{[30]}$

Table S2. Energy difference among three isomers 10a.

\begin{tabular}{lrrr}
\multicolumn{4}{c}{ DLPNO-CCSD $(\mathrm{T}) / \mathrm{def} 2-\mathrm{TZVP} / / \mathrm{B} 3 \mathrm{LYP}-\mathrm{D} 3(\mathrm{BJ}) / \mathrm{PCM} / \mathrm{def} 2-\mathrm{TZVP}$} \\
\hline & proximal-10a & distal-syn-10a & distal-anti-10a \\
\hline $\mathrm{G}$ (a.u.) & -1380.832 & -1380.825 & -1380.823 \\
$\Delta \mathrm{G}(\mathrm{kcal} / \mathrm{mol})$ & -6.0 & -1.8 & 0.0 \\
\hline
\end{tabular}

Table S3. EDA analysis of three isomers 10a.

EDA [MP2/cc-pVDZ//B3LYP-D3BJ/PCM/def2-TZVP]

(original)

\begin{tabular}{|c|c|c|c|c|c|c|}
\hline $\mathrm{E}(\mathrm{kcal} / \mathrm{mol})$ & ES & EX & REP & POL & DIS & Total \\
\hline proximal-10a & -254.9 & -396.3 & 808.1 & -282.7 & -4.9 & -130.6 \\
\hline distal-syn-10a & -258.5 & -382.5 & 793.2 & -285.5 & 10.9 & -122.4 \\
\hline distal-anti-10a & -254.0 & -376.1 & 777.3 & -282.5 & 10.9 & -124.5 \\
\hline $\mathrm{E}(\mathrm{kcal} / \mathrm{mol})$ & \multicolumn{6}{|c|}{ EX+REP } \\
\hline proximal-10a & \multicolumn{6}{|c|}{411.9} \\
\hline distal-syn-10a & \multicolumn{6}{|c|}{410.7} \\
\hline distal-anti-10a & \multicolumn{6}{|c|}{401.2} \\
\hline
\end{tabular}

EDA [MP2/cc-pVDZ//B3LYP-D3BJ/PCM/def2-TZVP]

(difference with distal-anti-10a)

\begin{tabular}{rrcrrr}
\hline$\Delta \mathrm{E}(\mathrm{kcal} / \mathrm{mol})$ & $\mathrm{ES}$ & $\mathrm{EX}+\mathrm{REP}$ & POL & DIS & Total \\
\hline proximal-10a & -0.8 & 10.7 & -0.2 & -15.7 & -6.0 \\
distal-syn-10a & -4.5 & 9.5 & -3.0 & 0.0 & 2.2 \\
distal-anti-10a & 0.0 & 0.0 & 0.0 & 0.0 & 0.0 \\
\hline
\end{tabular}


Table S4. Difference between B3LYP-D3(BJ) and B3LYP of three isomers 10a.

B3LYP-D3(BJ)/def2-QZVP//B3LYP-D3(BJ)/PCM/def2-TZVP, B3LYP/def2-QZVP//B3LYP-D3(BJ)/PCM/def2-TZVP

\begin{tabular}{lrrr}
\hline & proximal-10a & distal-syn-10a & distal-anti-10a \\
\hline B3LYP-D3(BJ) (a.u.) & -1384.217 & -1384.215 & -1384.212 \\
B3LYP (a.u.) & -1384.037 & -1384.055 & -1384.052 \\
$\Delta \mathrm{G}$ (a.u.) & -0.180 & -0.160 & -0.160 \\
$\Delta \mathrm{G}(\mathrm{kcal} / \mathrm{mol})$ & -112.9 & -100.5 & -100.6 \\
\hline
\end{tabular}

Table S5. Difference between B3LYP-D3(BJ) and B3LYP of 7a, proximal-11a, proximal-12a and proximal-10a.

B3LYP-D3(BJ)/def2-QZVP//B3LYP-D3(BJ)/PCM/def2-TZVP, B3LYP/def2-QZVP//B3LYP-D3(BJ)/PCM/def2-TZVP

\begin{tabular}{lrrrr}
\hline & 7a & proximal-11a & proximal-12a & proximal-10a \\
\hline B3LYP-D3(BJ) (a.u.) & -462.143 & -769.498 & -1076.861 & -1384.217 \\
B3LYP (a.u.) & -462.103 & -769.421 & -1076.739 & -1384.052 \\
$\Delta \mathrm{G}$ (a.u.) & -0.040 & -0.077 & -0.122 & -0.165 \\
$\Delta \mathrm{G}(\mathrm{kcal} / \mathrm{mol})$ & -25.3 & -48.2 & -76.4 & -103.6 \\
\hline
\end{tabular}

7a proximal-11a proximal-12a proximal-10a

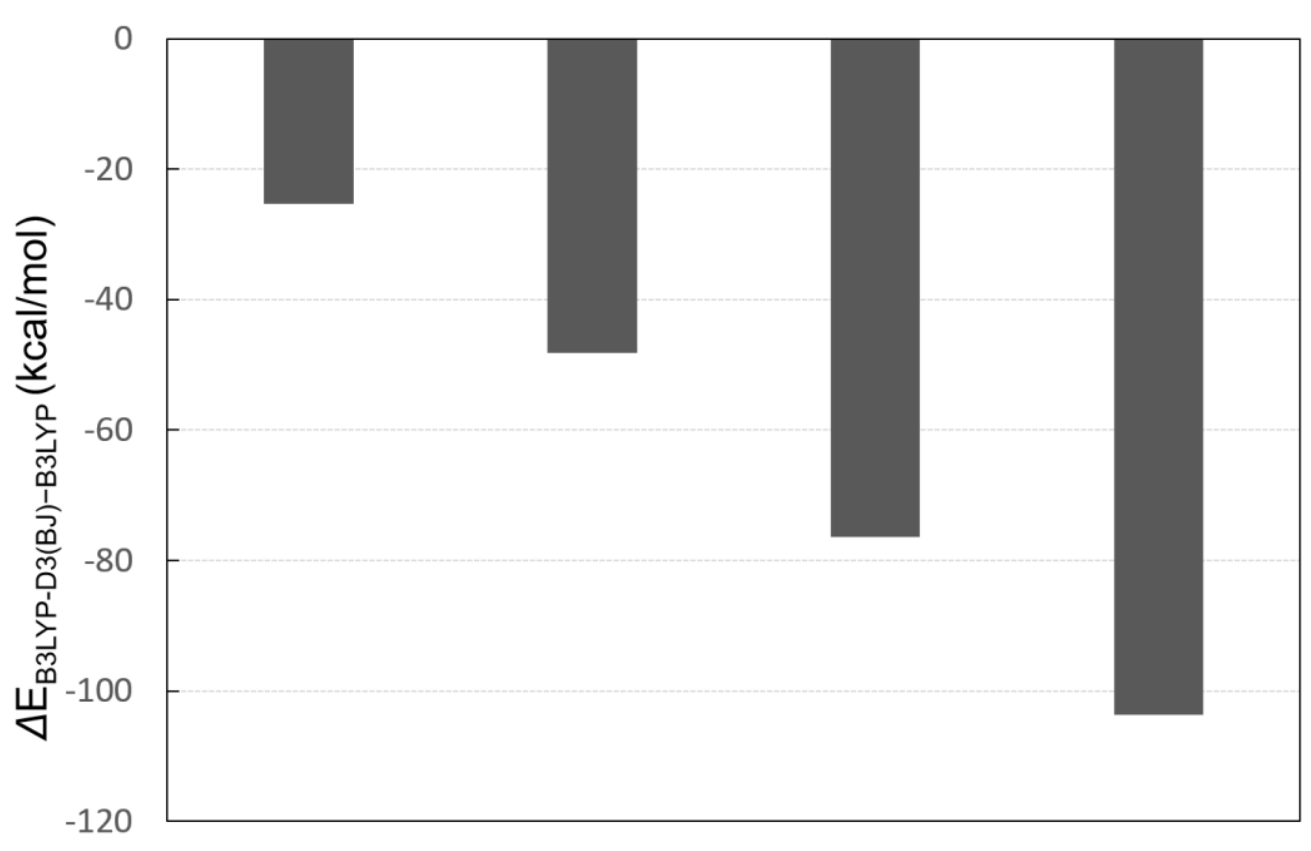

Figure S7. Energy difference between B3LYP-D3(BJ) and B3LYP. 
7. X-ray data of biphenylenes proximal-7e, proximal-7f, distal-7f, proximal-7h, proximal-7i, proximal-10a, proximal-10b, proximal-10d, and proximal-10e:

X-ray diffraction data of proximal-7e and proximal-10b were collected on a Rigaku Mercury CCD diffratomter employing graphite-monochromated Mo K $\alpha$ radiation and the others (proximal-7f, distal-7f, proximal-7h, proximal-7i, proximal-10a, proximal-10d, and proximal-10e) were collected on a Rigaku R-AXIS RAPID diffractometer employing graphite-monochromated $\mathrm{Cu} \mathrm{K} \alpha$ radiation. The structures were solved by direct method with SIR-92 program ${ }^{[31]}$ and refined with SHELXL program. ${ }^{[32]}$ The structural models were drawn with ORTEP-3 program. ${ }^{[33]}$ Further information on the crystal structure determinations have been deposited with the Cambridge Crystallographic Data Center (proximal-7e: CCDC 2019842, proximal-7f: CCDC 2019846, distal-7f: CCDC 2019852, proximal-7h: CCDC 2019853, proximal-7i: CCDC 2019854, proximal-10a: CCDC 2019859, proximal-10b: CCDC 2019862, proximal-10d: CCDC 2019865, and proximal10e: CCDC 2035060). Figure S8 shows the ORTEP drawing of compounds, proximal7e, proximal-7f, distal-7f, proximal-7h, proximal-7i, proximal-10a, proximal-10b, proximal-10d, and proximal-10e. The details of their refinements are given in Table S6. 


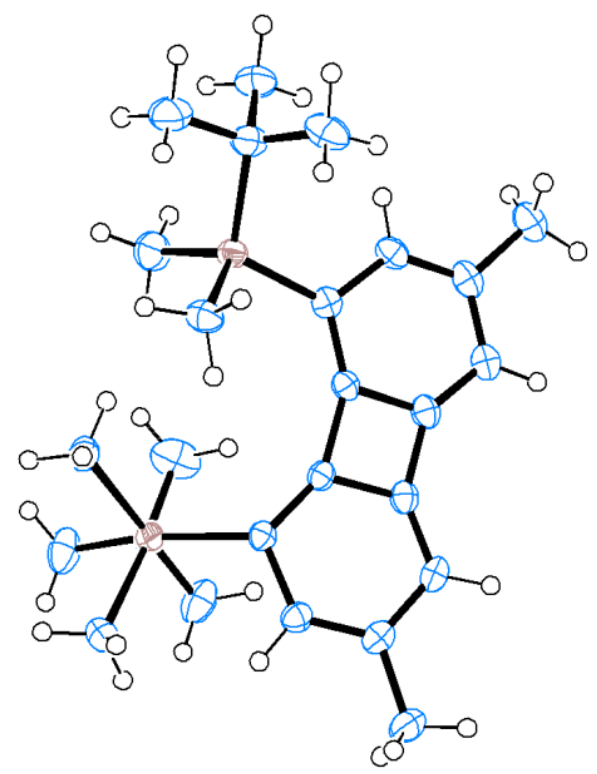

proximal-7e

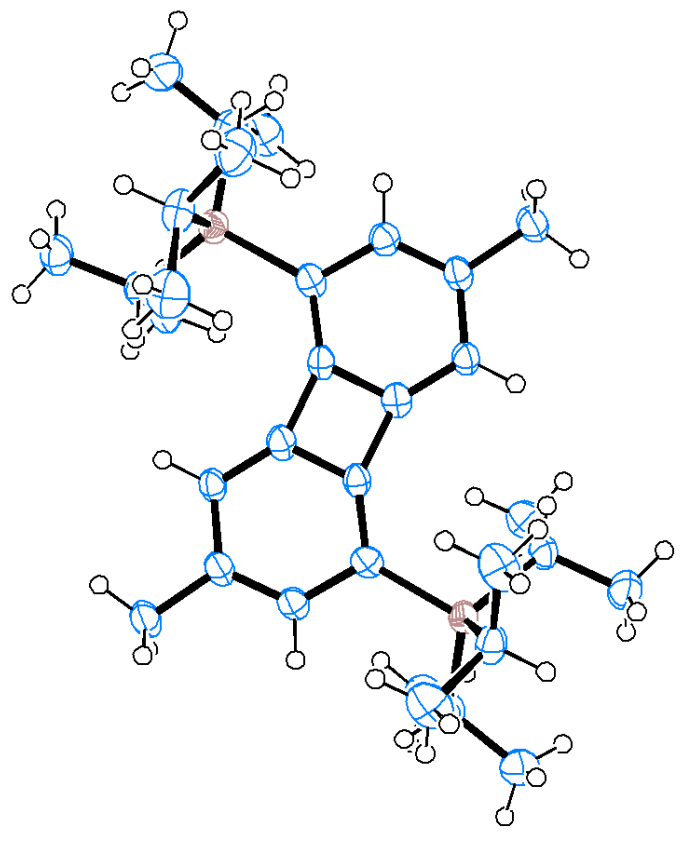

distal-7f

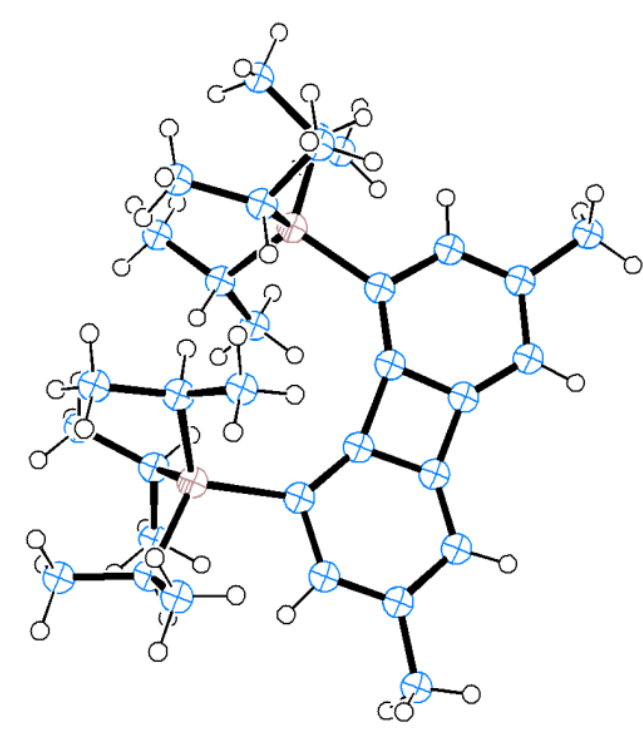

proximal-7f

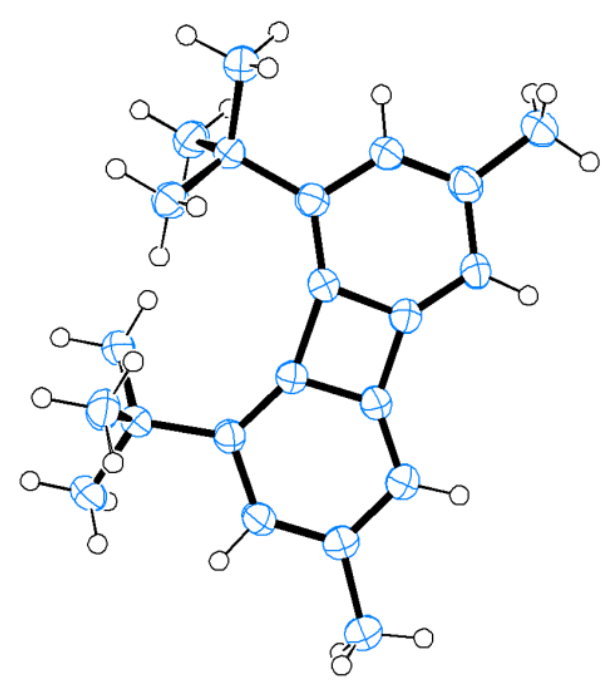

proximal-7h 


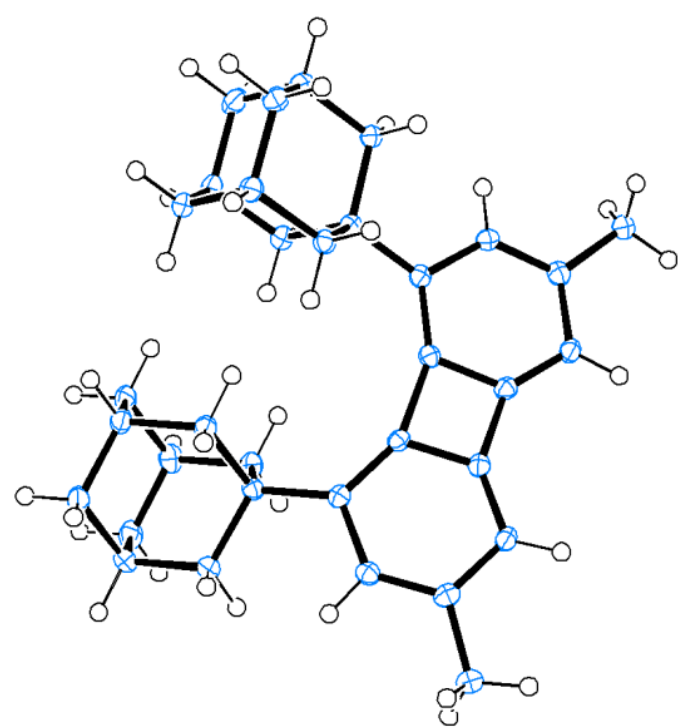

proximal-7i

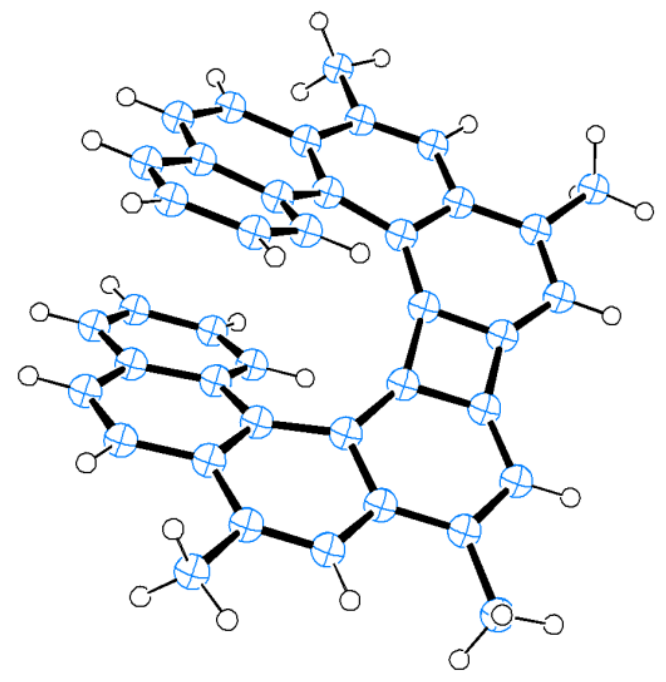

proximal-10b

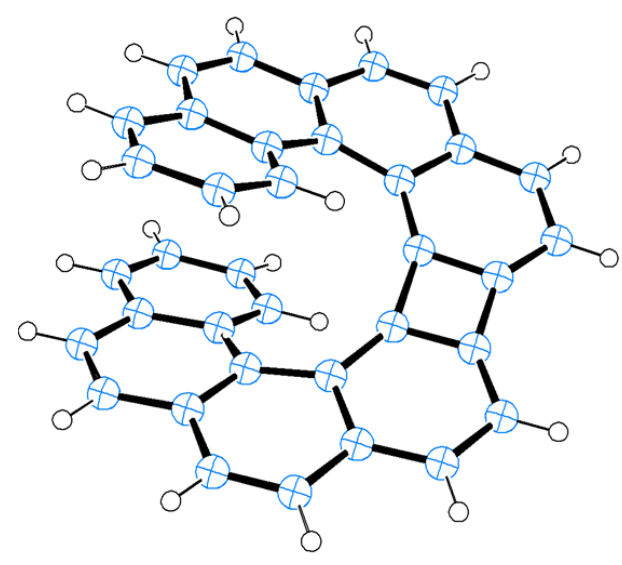

proximal-10a

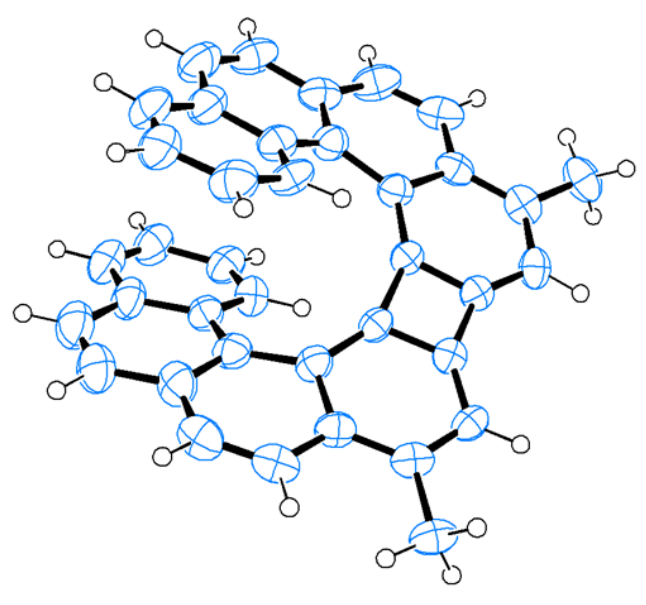

proximal-10d 


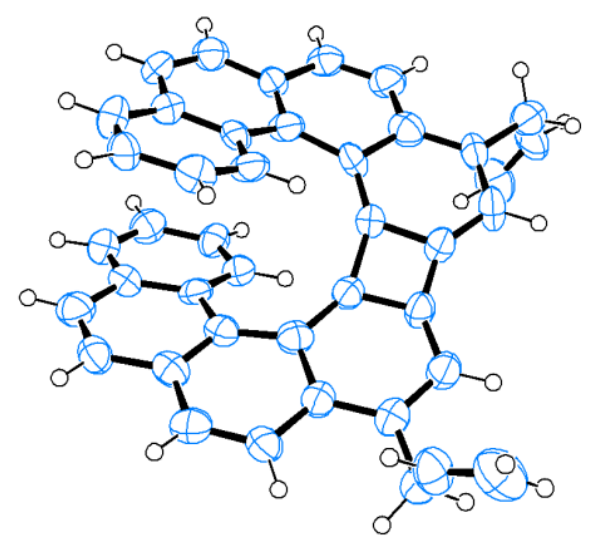

proximal-10e

Figure S8. X-ray structure of compounds proximal-7e, proximal-7f, distal-7f, proximal$\mathbf{7 h}$, proximal-7i, proximal-10a, proximal-10b, proximal-10d, and proximal-10e (thermal ellipsoid plot at the 50\% probability level) 
Table S6. Crystallographic data and structural refinement for compounds proximal-7e, proximal-7f, distal-7f, proximal-7h, proximal-7i, proximal-10a, proximal-10b, proximal-10d, and proximal-10e

\begin{tabular}{|l|c|c|c|c|}
\hline Compound & proximal-7e & proximal-7f & distal-7f & proximal-7h \\
\hline Empirical formula & $\mathrm{C}_{26} \mathrm{H}_{40} \mathrm{Si}_{2}$ & $\mathrm{C}_{32} \mathrm{H}_{52} \mathrm{Si}_{2}$ & $\mathrm{C}_{32} \mathrm{H}_{52} \mathrm{Si}_{2}$ & $\mathrm{C}_{22} \mathrm{H}_{28}$ \\
\hline Formula weight & 408.76 & 492.92 & 492.92 & 292.44 \\
\hline Temperature $(\mathrm{K})$ & 123 & 143 & 143 & 123 \\
\hline Crystal system & Monoclinic & Monoclinic & Triclinic & Orthorombic \\
\hline Space group & $P 2 / n$ & $C 2 / c$ & $P-1$ & Pbca \\
\hline$a(\AA)$ & $15.914(10)$ & $12.2589(4)$ & $7.9685(4)$ & $13.0881(2)$ \\
\hline$b(\AA)$ & $7.244(4)$ & $10.6537(4)$ & $14.7014(8)$ & $12.6289(2)$ \\
\hline$c(\AA)$ & $22.865(14)$ & $23.0386(8)$ & $14.8929(9)$ & $42.2301(8)$ \\
\hline$\alpha\left(^{\circ}\right)$ & 90 & 90 & $118.222(8)$ & 90 \\
\hline$\beta\left(^{\circ}\right)$ & $104.806(8)$ & $93.753(7)$ & $93.770(7)$ & 90 \\
\hline$\gamma\left(^{\circ}\right)$ & 90 & 90 & $98.558(7)$ & 90 \\
\hline Volume $\left(\AA^{3}\right)$ & $2548(3)$ & $3002.45(18)$ & $1501.5(2)$ & $6980.1(2)$ \\
\hline $\mathrm{Z}$ & 4 & 4 & 2 & 16 \\
\hline $\mathrm{D}_{\text {calcd }}\left(\mathrm{g} / \mathrm{cm}^{3}\right)$ & 1.066 & 1.090 & 1.090 & 1.113 \\
\hline$R_{1}$ & 0.0645 & 0.0544 & 0.0754 & 0.0653 \\
\hline $\mathrm{w} R_{2}$ & 0.2178 & 0.1455 & 0.2499 & 0.2608 \\
\hline $\mathrm{Goodness-of-fit}^{3}$ & 0.792 & 1.062 & 1.079 & 1.054 \\
\hline
\end{tabular}

\begin{tabular}{|l|c|c|c|c|}
\hline Compound & proximal-7i & proximal-10a & proximal-10b & proximal-10d \\
\hline Empirical formula & $\mathrm{C}_{34} \mathrm{H}_{40}$ & $\mathrm{C}_{36} \mathrm{H}_{20}$ & $\mathrm{C}_{40} \mathrm{H}_{28}$ & $\mathrm{C}_{38} \mathrm{H}_{24}$ \\
\hline Formula weight & 448.66 & 452.52 & 508.62 & 480.57 \\
\hline Temperature $(\mathrm{K})$ & 134 & 143 & 123 & 143 \\
\hline Crystal system & Monoclinic & Orthorombic & Monoclinic & Orthorombic \\
\hline Space group & $P 2_{1} / c$ & Pbcn & C2/c & Pcab \\
\hline$a(\AA)$ & $10.16742(18)$ & $12.8522(9)$ & $18.772(9)$ & $15.9562(3)$ \\
\hline$b(\AA)$ & $25.2343(5)$ & $11.0841(8)$ & $16.216(7)$ & $16.6914(3)$ \\
\hline$c(\AA)$ & $10.26922(19)$ & $15.6334(11)$ & $8.520(4)$ & $54.0146(10)$ \\
\hline$\alpha\left(^{\circ}\right)$ & 90 & 90 & 90 & 90 \\
\hline$\beta\left(^{\circ}\right)$ & $115.344(8)$ & 90 & $94.592(6)$ & 90 \\
\hline$\gamma\left(^{\circ}\right)$ & 90 & 90 & 90 & 90 \\
\hline Volume $\left(\AA^{3}\right)$ & $2381.17(18)$ & $2227.1(3)$ & $2585(2)$ & $14385.8(5)$ \\
\hline$Z$ & 4 & 4 & 4 & 24 \\
\hline$D_{\text {calcd }}\left(\mathrm{g} / \mathrm{cm}^{3}\right)$ & 1.252 & 1.350 & 1.307 & 1.331 \\
\hline$R_{1}$ & 0.0530 & 0.0331 & 0.0490 & 0.0959 \\
\hline $\mathrm{w} R_{2}$ & 0.1431 & 0.0897 & 0.1654 & 0.3106 \\
\hline Goodness-of-fit & 1.061 & 1.045 & 0.535 & 0.946 \\
\hline
\end{tabular}

\begin{tabular}{|l|c|}
\hline Compound & proximal-10e \\
\hline Empirical formula & $\mathrm{C}_{42} \mathrm{H}_{28}$ \\
\hline Formula weight & 532.67 \\
\hline Temperature $(\mathrm{K})$ & 143 \\
\hline Crystal system & Monoclinic \\
\hline Space group & $P 2_{1}$ \\
\hline$a(\AA)$ & $15.9356(5)$ \\
\hline$b(\AA)$ & $8.0195(3)$ \\
\hline$c(\AA)$ & $21.5561(7)$ \\
\hline$\alpha\left({ }^{\circ}\right)$ & 90 \\
\hline
\end{tabular}




\begin{tabular}{|l|c|}
\hline$\beta\left(^{\circ}\right)$ & $94.935(7)$ \\
\hline$\gamma\left({ }^{\circ}\right)$ & 90 \\
\hline Volume $\left(\AA^{3}\right)$ & $2744.56(16)$ \\
\hline $\mathrm{Z}$ & 2 \\
\hline $\mathrm{D}_{\text {calcd }}\left(\mathrm{g} / \mathrm{cm}^{3}\right)$ & 1.288 \\
\hline$R_{1}$ & 0.0861 \\
\hline $\mathrm{w} R_{2}$ & 0.3131 \\
\hline Goodness-of-fit & 0.0861 \\
\hline
\end{tabular}




\section{Experimental references:}

[1] Woodward, R. B.; Hoffmann, R. The Conservation of Orbital Symmetry. Angew. Chem., Int. Ed. Engl. 1969, 8, 781-932.

[2] Taha, M.; Marks, V.; Gottlieb, H. E.; Biali, S. E. Preparation and Conformation of Octaethylbiphenylene. J. Org. Chem. 2000, 65, 8621-8628.

[3] (a) Laird, D. W.; Gilbert, J. C. Norbornyne: A Cycloalkyne Reacting Like A Dicarbene. J. Am. Chem. Soc. 2001, 123, 6704-6705. (b) Bachrach, S. M.; Gilbert, J. C.; Laird, D. W. DFT Study of the Cycloaddition Reactions of Strained Alkynes. J. Am. Chem. Soc. 2001, 123, 6706-6707. (c) Bachrach, S. M.; Gilbert, J. C. The Reaction of Cyclopentyne with Ethene: Concerted vs Stepwise Mechanism? J. Org. Chem. 2004, 69, 6357-6364. (d) Ozkan, I.; Kinal, A. Competing Pathways in the [2+2] Cycloadditions of Cyclopentyne and Benzyne. A DFT and ab Initio Study. J. Org. Chem. 2004, 69, 53905394. (e) Kinal, A.; Piecuch, P. Is the Mechanism of the [2+2] Cycloaddition of Cyclopentyne to Ethylene Concerted or Biradical? A Completely Renormalized Coupled Cluster Study. J. Phys. Chem. A 2006, 110, 367-378.

[4] Foresman, J. B.; Frisch, Æ. Exploring Chemistry with Electronic Structure Methods, 3rd ed. Gaussian, Inc., Wallingford, CT, 2015. (b) CASPT2: Shiozaki, T.; Werner, H.-J. Second-order multireference perturbation theory with explicit correlation: CASPT2-F12. J. Chem. Phys. 2010, 133, 141103. (c) CASPT2: Shiozaki, T.; Woywod C.; Werner, H.-J. Pyrazine excited states revisited using the extended multi-state complete active space second-order perturbation method. Phys. Chem. Chem. Phys. 2013, 15, 262-269.

[5] Gaussian 16, Revision C.01, Frisch, M. J.; Trucks, G. W.; Schlegel, H. B.; Scuseria, G. E.; Robb, M. A.; Cheeseman, J. R.; Scalmani, G.; Barone, V.; Petersson, G. A.; Nakatsuji, H.; Li, X.; Caricato, M.; Marenich, A. V.; Bloino, J.; Janesko, B. G.; Gomperts, R.; Mennucci, B.; Hratchian, H. P.; Ortiz, J. V.; Izmaylov, A. F.; Sonnenberg, J. L.; Williams-Young, D.; Ding, F.; Lipparini, F.; Egidi, F.; Goings, J.; Peng, B.; Petrone, A.; Henderson, T.; Ranasinghe, D.; Zakrzewski, V. G.; Gao, J.; Rega, N.; Zheng, G.; Liang, 
W.; Hada, M.; Ehara, M.; Toyota, K.; Fukuda, R.; Hasegawa, J.; Ishida, M.; Nakajima, T.; Honda, Y.; Kitao, O.; Nakai, H.; Vreven, T.; Throssell, K.; Montgomery, J. A., Jr.; Peralta, J. E.; Ogliaro, F.; Bearpark, M. J.; Heyd, J. J.; Brothers, E. N.; Kudin, K. N.; Staroverov, V. N.; Keith, T. A.; Kobayashi, R.; Normand, J.; Raghavachari, K.; Rendell, A. P.; Burant, J. C.; Iyengar, S. S.; Tomasi, J.; Cossi, M.; Millam, J. M.; Klene, M.; Adamo, C.; Cammi, R.; Ochterski, J. W.; Martin, R. L.; Morokuma, K.; Farkas, O.; Foresman, J. B.; Fox, D. J. Gaussian, Inc., Wallingford CT, 2016.

[6] Yang, T.; Nagase, S.; Akasaka, T.; Poblet, J. M.; Houk, K. N.; Ehara, M.; Zhao, X. $(2+2)$ Cycloaddition of Benzyne to Endohedral Metallofullerenes M3N@C80 (M = Sc, Y): A Rotating-Intermediate Mechanism. J. Am. Chem. Soc. 2015, 137, 6820-6828.

[7] Su, P.; Li, H. Energy decomposition analysis of covalent bonds and intermolecular interactions. J. Chem. Phys. 2009, 131, 014102.

[8] Examples of energy decomposition analysis (EDA) and evaluation of dispersion, see. Rösel, S.; Quanz, H.; Logemann, C.; Becker, J.; Mossou, E.; Cañadillas-Delgado, L.; Caldeweyher, E.; Grimme, S.; Schreiner, P. R. London Dispersion Enables the Shortest Intermolecular Hydrocarbon H $\cdots$ H Contact. J. Am. Chem. Soc. 2017, 139, 7428-7431. [9] (a) Schmidt, M. W.; Baldridge, K. K.; Boatz, J. A.; Elbert, S. T.; Gordon, M. S.; Jensen, J. H.; Koseki, S.; Matsunaga, N.; Nguyen, K. A.; Su, S.; Windus, T. L.; Dupuis, M.; Montgomery, J. A. General Atomic and Molecular Electronic Structure System. J. Comput. Chem. 1993, 14, 1347-1363. (b) Advances in electronic structure theory:

GAMESS a decade later. Gordon, M. S.; Schmidt, M. W. pp. 1167-1189, in Theory and Applications of Computational Chemistry: the first forty years. Dykstra, C. E.; Frenking, G.; Kim, K. S.; Scuseria, G. E. Eds., Elsevier, Amsterdam, 2005.

[10] Ikawa, T.; Takagi, A.; Kurita, Y.; Saito, K.; Azechi, K.; Egi, M.; Kakiguchi, K.; Kita, Y.; Akai, S. Preparation and Regioselective Diels-Alder Reactions of Borylbenzynes: Synthesis of Functionalized Arylboronates. Angew. Chem. Int. Ed. 2010, 49, 5563-5566 [11] Breunig, M.; Yuan, P.; Gaich, T. An Unexpected Transannular [4+2] Cycloaddition during the Total Synthesis of (+)-Norcembrene 5. Angew. Chem. Int. Ed. 2020, 59, 55215525 .

[12] Still, W. C.; Kahn, M.; Mitra, A. Rapid chromatographic technique for preparative separations with moderate resolution. J. Org. Chem. 1978, 43, 2923-2925. 
[13] Aikawa, H.; Takahira; Y.; Yamaguchi, M. Synthesis of 1,8-di(1adamantyl)naphthalenes as single enantiomers stable at ambient temperatures. Chem. Commun. 2011, 47, 1479-1481.

[14] Akai, S.; Ikawa, T.; Takayanagi, S.; Morikawa, Y.; Mohri, S.; Tsubakiyama, M.; Egi, M.; Wada, Y.; Kita, Y. Synthesis of Biaryl Compounds through Three-Component Assembly: Ambidentate Effect of the tert-Butyldimethylsilyl Group for Regioselective Diels-Alder and Hiyama Coupling Reactions. Angew. Chem. Int. Ed. 2008, 47, 76737676.

[15] Anderson, J. E.; Franck, R. W.; Mandella, W. L. Peri interactions in some 1,8-di-tertbutylnaphthalene compounds. Rotation and flipping of the tert-butyl groups. J. Am. Chem. Soc. 1972, 94, 4608-4614.

[16] Ayub, Rabia; Papadakis, Raffaello; Jorner, Kjell; Zietz, Burkhard; Ottosson, Henrik, Cyclopropyl Group: An Excited-State Aromaticity Indicator? Chem. Eur. J. 2017, 23, 13684-13695.

[17] Ooi, T.; Takahashi, M.; Yamada, M.; Tayama, E.; Omoto, K.; Maruoka K. (2,7Disubstituted-1,8-biphenylenedioxy)bis(dimethylaluminum) as Bidentate Organoaluminum Lewis Acids: Elucidation and Synthetic Utility of the Double Electrophilic Activation Phenomenon. J. Am. Chem. Soc. 2004, 126, 1150-1160.

[18] Jack Hine, Soonkap Hahn, David E. Miles, and Kyunghye Ahn The synthesis and ionization constants of some derivatives of 1-biphenylenol. J. Org. Chem. 1985, 50, 5092-5096.

[19] Commercially available

[20] Qin, L.; Ren, L.; Wan, S.; Liu, G.; Luo, X.; Liu, Z.; Li, F.; Yu, Y.; Liu, J.; Wei, Y. Design, Synthesis, and Evaluation of Novel 2,6-Disubstituted Phenol Derivatives as General Anesthetics. J. Med. Chem. 2017, 60, 3606-3617.

[21] Bárbara V. Moreira, Ana Carolina A. Muraca, Cristiano Raminelli Synthesis of Silylbiaryl Triflates by Chemoselective Suzuki Reaction. Synthesis 2017, 49, 1093-1102. [22] Michellys, P.-Y.; Ardecky, R. J.; Chen, J.-H.; D’Arrigo, J.; Grese, T. A.; Karanewsky, D. S.; Leibowitz, M. D.; Liu, S.; Mais, D. A.; Mapes, C. M.; Montrose-Rafizadeh, C.; Ogilvie, K. M.; Reifel-Miller, A.; Rungta, D.; Thompson, A. W.; Tyhonas, J. S.; Boehm, M. F. 1-[[(3-Hydroxy-1-adamantyl)amino]acetyl]-2-cyano-(S)-pyrrolidine: A Potent, 
Selective, and Orally Bioavailable Dipeptidyl Peptidase IV Inhibitor with Antihyperglycemic Properties. J. Med. Chem. 2003, 46, 4087-4103.

[23] Fuchibe, K.; Morikawa, T.; Shigeno, K.; Fujita, T.; Ichikawa; J. Pinpoint-Fluorinated Phenacenes: New Synthesis and Solubility Enhancement Strategies. Org. Lett. 2015, 17, $1126-1129$.

[24] Mohammad-Pour, G. S.; Ly, R. T.; Fairchild, D. C.; Burnstine-Townley, A.; VazquezMolina, D. A.; Trieu, K. D.; Campiglia, A. D.; Harper, J. K.; Uribe-Romo, F. J. Modular Design of Fluorescent Dibenzo- and Naphtho-Fluoranthenes: Structural Rearrangements and Electronic Properties. J. Org. Chem. 2018, 83, 8036-8053.

[25] Neese F. The ORCA program system. WIREs Comput. Mol. Sci. 2012, 2, 73-78.

[26] (a) LMOEDA; Su, P.; Li, H. Energy decomposition analysis of covalent bonds and intermolecular interactions. J. Chem. Phys. 2009, 131, 014102.

[27] (a) Kitaura, K.; Ikeo, E.; Asada, T. ; Nakano, T.; Uebayasi, M. Fragment molecular orbital method: an approximate computational method for large molecules. Chem. Phys. Lett. 1999, 313, 701-706. (b) Fedorov, D. G.; Kitaura, K. Extending the Power of Quantum Chemistry to Large Systems with the Fragment Molecular Orbital Method. $J$. Phys. Chem. A 2007, 111, 6904-6914.

[28] Contreras-García, J.; Johnson, E. R.; Keinan, S.; Chaudret, R.; Piquemal, J.-P.; Beratan, D. N.; Yang, W. NCIPLOT: A Program for Plotting Noncovalent Interaction Regions. J. Chem. Theory Comput. 2011, 7, 625-632

[29] Tomasi, J.; Mennucci, B.; Cammi, R. Quantum mechanical continuum solvation models. Chem. Rev. 2005, 105 2999-3093.

[30] Legault, C. Y. CYLview, 1.0b; Université de Sherbrooke, Canada, 2009; http://www.cylview.org

[31] Altomare, A.; Cascarano, G.; Giacovazzo, C.; Guagliardi, A. Completion and Refinement of Crystal Structures with SIR92. J. Appl. Cryst. 1993, 26, 343-350.

[32] Sheldrick, G. M. Crystal structure refinement with SHELXL. Acta Cryst. 2008, A64, $112-122$.

[33] Farrugia, L. J. ORTEP-3 for Windows - a version of ORTEP-III with a Graphical User Interface (GUI). J. Appl. Cryst. 1997, 30, 565. 


\section{Cartesian coordinates:}

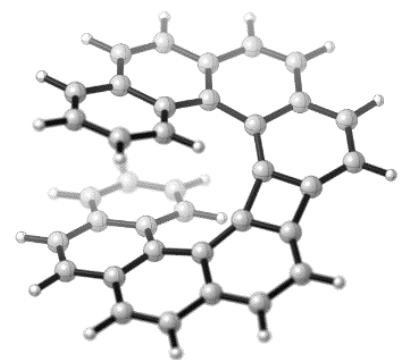

proximal-10a

$\begin{array}{lllll}1 & \mathrm{C} & 3.511421 & -2.187416 & -0.277327\end{array}$

$\begin{array}{lllll}2 & \mathrm{C} & 3.363818 & -0.775080 & -0.195411\end{array}$

$\begin{array}{lllll}3 & \mathrm{C} & 2.133144 & -0.174138 & -0.514940\end{array}$

$\begin{array}{llllll}4 & \mathrm{C} & & 1.133756 & -0.976851 & -1.169080\end{array}$

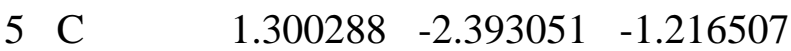

$\begin{array}{llllll}6 & \mathrm{C} & 2.495393 & -2.974657 & -0.716121\end{array}$

$\begin{array}{lllll}7 \mathrm{C} & 1.959742 & 1.233502 & -0.213054\end{array}$

$\begin{array}{lllll}8 & \mathrm{C} & 0.768434 & 1.943208 & -0.065566\end{array}$

$\begin{array}{lllll}9 & \mathrm{C} & -0.798288 & -2.625816 & -2.403361\end{array}$

10 C $\quad \begin{array}{llll}0.301966 & -3.192343 & -1.809629\end{array}$

$11 \mathrm{H} \quad 0.429235 \quad-4.267901 \quad-1.801228$

$\begin{array}{llll}12 \mathrm{H} & -1.560277 & -3.249109 & -2.852218\end{array}$

$13 \mathrm{H} \quad 4.453211 \quad-2.623712 \quad 0.031670$

$14 \mathrm{H} \quad 2.599706 \quad-4.052237 \quad-0.740284$

$\begin{array}{llll}15 \mathrm{C} & 4.484667 & 0.029881 & 0.178349\end{array}$

$\begin{array}{llll}16 \mathrm{C} & 4.399073 & 1.381054 & 0.197095\end{array}$

$\begin{array}{llll}17 \mathrm{C} & 3.147072 & 2.041449 & 0.009610\end{array}$

$\begin{array}{llll}18 \mathrm{H} & 5.272241 & 1.988128 & 0.401184\end{array}$

$\begin{array}{llll}19 \mathrm{C} & 3.083054 & 3.437851 & 0.121772\end{array}$

$\begin{array}{llll}20 \mathrm{C} & 1.876218 & 4.135836 & 0.071573\end{array}$

$\begin{array}{llll}21 \mathrm{C} & 0.747339 & 3.354134 & -0.002838\end{array}$

$\begin{array}{llll}22 \mathrm{H} & 1.844067 & 5.214889 & 0.134079\end{array}$

$23 \mathrm{C} \quad-0.912875 \quad-1.227726 \quad-2.455528$ 


\begin{tabular}{|c|c|c|c|}
\hline $24 \mathrm{H}$ & -1.751672 & -0.773837 & -2.966607 \\
\hline $25 \mathrm{C}$ & 0.030041 & -0.427913 & -1.857211 \\
\hline $6 \mathrm{H}$ & -0.070249 & 0.641915 & -1.931997 \\
\hline $7 \mathrm{C}$ & -3.511422 & -2.187417 & 0.277329 \\
\hline $8 \mathrm{C}$ & -3.363818 & -0.775081 & 0.195413 \\
\hline $29 \mathrm{C}$ & -2.133145 & -0.174139 & 0.514942 \\
\hline $\mathrm{C}$ & -1.133756 & -0.976853 & 1.169081 \\
\hline $31 \mathrm{C}$ & -1.300287 & -2.393053 & 1.216505 \\
\hline $32 \mathrm{C}$ & -2.495393 & -2.974658 & 0.716121 \\
\hline $33 \mathrm{C}$ & -1.959742 & 1.233501 & 0.213054 \\
\hline $34 \mathrm{C}$ & -0.768434 & 1.943208 & 0.065566 \\
\hline $35 \mathrm{C}$ & 0.798291 & -2.625820 & 2.403356 \\
\hline $36 \mathrm{C}$ & -0.301965 & -3.192346 & 1.809625 \\
\hline $37 \mathrm{H}$ & -0.429233 & -4.267904 & 1.801221 \\
\hline $38 \mathrm{H}$ & 1.560280 & -3.249114 & 2.852211 \\
\hline $39 \mathrm{H}$ & -4.453211 & -2.623713 & -0.031668 \\
\hline $40 \mathrm{H}$ & -2.599705 & -4.052239 & 0.740282 \\
\hline $41 \mathrm{C}$ & -4.484667 & 0.029880 & -0.178346 \\
\hline $42 \mathrm{C}$ & -4.399073 & 1.381053 & -0.197093 \\
\hline $43 \mathrm{C}$ & -3.147072 & 2.041448 & -0.009609 \\
\hline $44 \mathrm{H}$ & -5.272241 & 1.988127 & -0.401182 \\
\hline $45 \mathrm{C}$ & -3.083055 & 3.437850 & -0.121772 \\
\hline $46 \mathrm{C}$ & -1.876219 & 4.135835 & -0.071573 \\
\hline $47 \mathrm{C}$ & -0.747340 & 3.354134 & 0.002838 \\
\hline $48 \mathrm{H}$ & -1.844069 & 5.214889 & -0.134079 \\
\hline $49 \mathrm{C}$ & 0.912877 & -1.227730 & 2.455526 \\
\hline $50 \mathrm{H}$ & 1.751673 & -0.773842 & 2.966606 \\
\hline $51 \mathrm{C}$ & -0.030040 & -0.427916 & 1.857213 \\
\hline $52 \mathrm{H}$ & 0.070249 & 0.641911 & 1.932001 \\
\hline $53 \mathrm{H}$ & -5.424246 & -0.466131 & -0.387542 \\
\hline $54 \mathrm{H}$ & -4.010492 & 3.976546 & -0.270409 \\
\hline $55 \mathrm{H}$ & 4.010491 & 3.976548 & 0.270410 \\
\hline
\end{tabular}




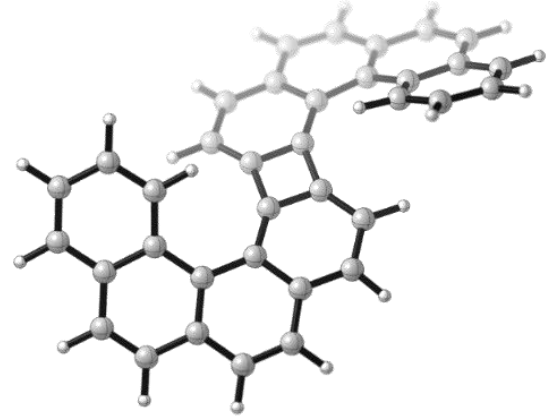

distal-syn-10a

$\begin{array}{lllll}1 & \mathrm{C} & 5.772212 & 1.154499 & -0.909755 \\ 2 \mathrm{C} & 4.442862 & 1.632287 & -0.735915 \\ 3 \mathrm{C} & 3.456820 & 0.791086 & -0.187167 \\ 4 \mathrm{C} & 3.878963 & -0.442696 & 0.426616 \\ 5 \mathrm{C} & 5.211908 & -0.907347 & 0.210656 \\ 6 \mathrm{C} & 6.129431 & -0.093431 & -0.507814 \\ 7 \mathrm{C} & 2.078103 & 1.234099 & -0.243113 \\ 8 \mathrm{C} & 0.941401 & 0.441911 & -0.138954 \\ 9 \mathrm{C} & 4.790274 & -2.849677 & 1.598583 \\ 10 \mathrm{C} & 5.625104 & -2.131671 & 0.777542 \\ 11 \mathrm{H} & 6.631165 & -2.479575 & 0.577588 \\ 12 \mathrm{H} & 5.123148 & -3.780581 & 2.038636 \\ 13 \mathrm{H} & 6.493965 & 1.807647 & -1.384204 \\ 14 \mathrm{H} & 7.134042 & -0.462217 & -0.673295 \\ 15 \mathrm{C} & 4.122527 & 2.979200 & -1.093926 \\ 16 \mathrm{C} & 2.871367 & 3.473491 & -0.931915 \\ 17 \mathrm{C} & 1.793217 & 2.624439 & -0.541617 \\ 18 \mathrm{H} & 2.654249 & 4.509939 & -1.158312 \\ 19 \mathrm{C} & 0.478749 & 3.115012 & -0.566515 \\ 20 \mathrm{C} & -0.636975 & 2.298634 & -0.371583\end{array}$




\begin{tabular}{|c|c|c|c|}
\hline $21 \mathrm{C}$ & -0.369195 & 0.961597 & -0.174158 \\
\hline $22 \mathrm{H}$ & -1.638532 & 2.697988 & -0.423292 \\
\hline $3 \mathrm{C}$ & 3.516449 & -2.342193 & 1.903021 \\
\hline$+\mathrm{H}$ & 2.878084 & -2.869626 & 2.599853 \\
\hline $\mathrm{C}$ & 3.075896 & -1.171958 & 1.331650 \\
\hline $26 \mathrm{H}$ & 2.108286 & -0.787819 & 1.609405 \\
\hline $27 \mathrm{C}$ & -5.772158 & -1.154503 & -0.909895 \\
\hline $28 \mathrm{C}$ & -4.442822 & -1.632295 & -0.735962 \\
\hline $29 \mathrm{C}$ & -3.456804 & -0.791080 & -0.187192 \\
\hline $30 \mathrm{C}$ & -3.878979 & 0.442712 & 0.426551 \\
\hline $31 \mathrm{C}$ & -5.211908 & 0.907367 & 0.210500 \\
\hline $32 \mathrm{C}$ & -6.129391 & 0.093443 & -0.508012 \\
\hline $33 \mathrm{C}$ & -2.078085 & -1.234099 & -0.243071 \\
\hline $34 \mathrm{C}$ & -0.941384 & -0.441906 & -0.138945 \\
\hline $35 \mathrm{C}$ & -4.790361 & 2.849704 & 1.598443 \\
\hline $36 \mathrm{C}$ & -5.625137 & 2.131697 & 0.777347 \\
\hline $37 \mathrm{H}$ & -6.631183 & 2.479606 & 0.577322 \\
\hline $38 \mathrm{H}$ & -5.123261 & 3.780610 & 2.038468 \\
\hline $39 \mathrm{H}$ & -6.493888 & -1.807658 & -1.384369 \\
\hline $40 \mathrm{H}$ & -7.133989 & 0.462231 & -0.673564 \\
\hline $41 \mathrm{C}$ & -4.122477 & -2.979227 & -1.093894 \\
\hline $42 \mathrm{C}$ & -2.871332 & -3.473522 & -0.931786 \\
\hline $43 \mathrm{C}$ & -1.793195 & -2.624457 & -0.541481 \\
\hline $44 \mathrm{H}$ & -2.654211 & -4.509983 & -1.158118 \\
\hline $45 \mathrm{C}$ & -0.478727 & -3.115038 & -0.566291 \\
\hline $46 \mathrm{C}$ & 0.636993 & -2.298652 & -0.371373 \\
\hline $47 \mathrm{C}$ & 0.369213 & -0.961596 & -0.174070 \\
\hline $48 \mathrm{H}$ & 1.638548 & -2.698016 & -0.423019 \\
\hline $49 \mathrm{C}$ & -3.516562 & 2.342210 & 1.902978 \\
\hline $50 \mathrm{H}$ & -2.878246 & 2.869641 & 2.599856 \\
\hline $51 \mathrm{C}$ & -3.075975 & 1.171970 & 1.331644 \\
\hline $52 \mathrm{H}$ & -2.108390 & 0.787824 & 1.609475 \\
\hline
\end{tabular}




$\begin{array}{lllll}53 \mathrm{H} & -4.919367 & -3.611320 & -1.465297 \\ 54 \mathrm{H} & -0.335905 & -4.163953 & -0.794142 \\ 55 \mathrm{H} & 4.919432 & 3.611281 & -1.465316 \\ 56 \mathrm{H} & 0.335932 & 4.163911 & -0.794443\end{array}$

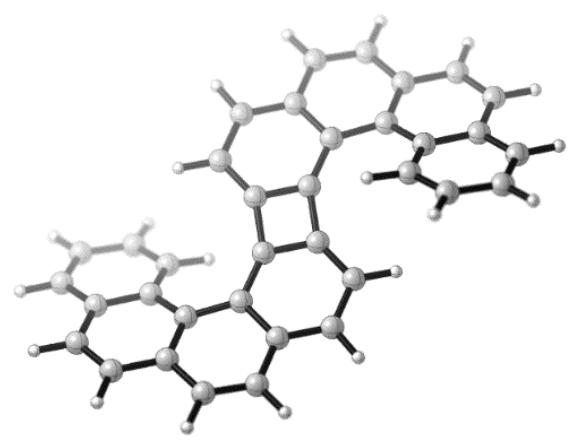

distal-anti-10a

$\begin{array}{lllll}1 & \mathrm{C} & -5.707758 & 1.494506 & -0.648687 \\ 2 & \mathrm{C} & -4.393631 & 1.845064 & -0.228843 \\ 3 & \mathrm{C} & -3.455097 & 0.837534 & 0.061025 \\ 4 \mathrm{C} & -3.932912 & -0.513202 & 0.203673 \\ 5 \mathrm{C} & -5.249945 & -0.838490 & -0.241913 \\ 6 \mathrm{C} & -6.102520 & 0.195658 & -0.715596 \\ 7 \mathrm{C} & -2.071297 & 1.230406 & 0.245079 \\ 8 \mathrm{C} & -0.941743 & 0.432878 & 0.100248 \\ 9 \mathrm{C} & -4.956614 & -3.132169 & 0.485152 \\ 10 \mathrm{C} & -5.717201 & -2.164714 & -0.125499 \\ 11 \mathrm{H} & -6.707830 & -2.398114 & -0.496156 \\ 12 \mathrm{H} & -5.332598 & -4.142104 & 0.583731 \\ 13 \mathrm{H} & -6.387975 & 2.291263 & -0.922833 \\ 14 \mathrm{H} & -7.094071 & -0.064371 & -1.064619 \\ 15 \mathrm{C} & -4.045079 & 3.222060 & -0.061292 \\ 16 \mathrm{C} & -2.815469 & 3.587086 & 0.375605 \\ 17 \mathrm{C} & -1.771677 & 2.623767 & 0.513357\end{array}$




\begin{tabular}{|c|c|c|c|}
\hline $18 \mathrm{H}$ & -2.582995 & 4.627688 & 0.564436 \\
\hline $19 \mathrm{C}$ & -0.467204 & 3.047571 & 0.804402 \\
\hline $20 \mathrm{C}$ & 0.635298 & 2.193416 & 0.739377 \\
\hline $1 \mathrm{C}$ & 0.368993 & 0.907365 & 0.322977 \\
\hline $2 \mathrm{H}$ & 1.630842 & 2.552637 & 0.947947 \\
\hline $3 \mathrm{C}$ & -3.706276 & -2.790335 & 1.026223 \\
\hline $4 \mathrm{H}$ & -3.130684 & -3.531771 & 1.565026 \\
\hline $25 \mathrm{C}$ & -3.209685 & -1.516006 & 0.885587 \\
\hline $26 \mathrm{H}$ & -2.262820 & -1.268999 & 1.337438 \\
\hline $27 \mathrm{C}$ & 5.707748 & -1.494422 & 0.648766 \\
\hline $28 \mathrm{C}$ & 4.393606 & -1.845009 & 0.228992 \\
\hline $29 \mathrm{C}$ & 3.455078 & -0.837498 & -0.060966 \\
\hline $30 \mathrm{C}$ & 3.932929 & 0.513201 & -0.203842 \\
\hline $31 \mathrm{C}$ & 5.249979 & 0.838524 & 0.241672 \\
\hline $32 \mathrm{C}$ & 6.102535 & -0.195574 & 0.715498 \\
\hline $33 \mathrm{C}$ & 2.071263 & -1.230373 & -0.244918 \\
\hline $34 \mathrm{C}$ & 0.941708 & -0.432851 & -0.100029 \\
\hline $35 \mathrm{C}$ & 4.956719 & 3.132084 & -0.485795 \\
\hline $36 \mathrm{C}$ & 5.717274 & 2.164714 & 0.125029 \\
\hline $37 \mathrm{H}$ & 6.707914 & 2.398146 & 0.495639 \\
\hline $38 \mathrm{H}$ & 5.332736 & 4.141990 & -0.584555 \\
\hline $39 \mathrm{H}$ & 6.387956 & -2.291157 & 0.922998 \\
\hline $40 \mathrm{H}$ & 7.094100 & 0.064482 & 1.064462 \\
\hline $41 \mathrm{C}$ & 4.045036 & -3.222018 & 0.061592 \\
\hline $42 \mathrm{C}$ & 2.815416 & -3.587072 & -0.375251 \\
\hline $43 \mathrm{C}$ & 1.771629 & -2.623758 & -0.513066 \\
\hline $44 \mathrm{H}$ & 2.582927 & -4.627691 & -0.563972 \\
\hline $45 \mathrm{C}$ & 0.467143 & -3.047590 & -0.804012 \\
\hline $46 \mathrm{C}$ & -0.635358 & -2.193435 & -0.738990 \\
\hline $47 \mathrm{C}$ & -0.369035 & -0.907360 & -0.322681 \\
\hline $48 \mathrm{H}$ & -1.630913 & -2.552670 & -0.947491 \\
\hline $49 \mathrm{C}$ & 3.706377 & 2.790189 & -1.026817 \\
\hline
\end{tabular}




$\begin{array}{lllll}50 \mathrm{H} & 3.130813 & 3.531544 & -1.565762 \\ 51 \mathrm{C} & 3.209743 & 1.515902 & -0.885951 \\ 52 \mathrm{H} & 2.262879 & 1.268839 & -1.337771 \\ 53 \mathrm{H} & 4.808203 & -3.967921 & 0.245209 \\ 54 \mathrm{H} & 0.315258 & -4.094168 & -1.037108 \\ 55 \mathrm{H} & -4.808250 & 3.967973 & -0.244851 \\ 56 \mathrm{H} & -0.315327 & 4.094132 & 1.037583\end{array}$

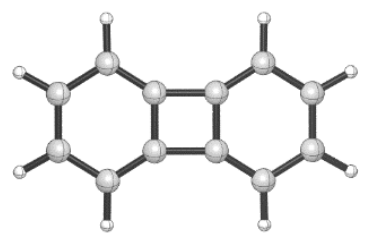

$7 a$

$\begin{array}{lllll}1 & \mathrm{C} & 0.000000 & 0.692358 & 3.113450 \\ 2 & \mathrm{C} & 0.000000 & 1.441221 & 1.911126 \\ 3 & \mathrm{C} & 0.000000 & 0.711089 & 0.754824 \\ 4 & \mathrm{C} & -0.000000 & -0.711089 & 0.754824 \\ 5 & \mathrm{C} & -0.000000 & -1.441221 & 1.911126 \\ 6 & \mathrm{C} & -0.000000 & -0.692358 & 3.113450 \\ 7 & \mathrm{H} & 0.000000 & 1.217972 & 4.059600 \\ 8 \mathrm{H} & 0.000000 & 2.522837 & 1.931440 \\ 9 & \mathrm{H} & -0.000000 & -2.522837 & 1.931440 \\ 10 \mathrm{H} & -0.000000 & -1.217972 & 4.059600 \\ 11 \mathrm{C} & 0.000000 & 0.711089 & -0.754824 \\ 12 \mathrm{C} & 0.000000 & 1.441221 & -1.911126 \\ 13 \mathrm{C} & 0.000000 & 0.692358 & -3.113450 \\ 14 \mathrm{C} & -0.000000 & -0.692358 & -3.113450 \\ 15 \mathrm{C} & -0.000000 & -1.441221 & -1.911126 \\ 16 \mathrm{C} & -0.000000 & -0.711089 & -0.754824\end{array}$




\begin{tabular}{|c|c|c|c|}
\hline $17 \mathrm{H}$ & 0.000000 & 2.522837 & -1.931440 \\
\hline $18 \mathrm{I}$ & 0.000000 & 1.217972 & -4.059600 \\
\hline $19 \mathrm{H}$ & -0.000000 & -1.217972 & -4.059600 \\
\hline 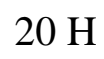 & -0.000000 & -2.522837 & -1.93 \\
\hline
\end{tabular}

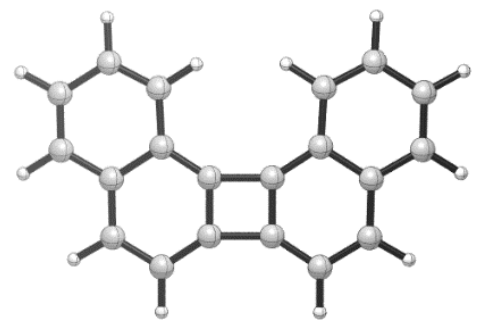

proximal-11a

$\begin{array}{lllll}1 & \mathrm{C} & -0.000000 & 3.222884 & -2.423718\end{array}$

$\begin{array}{llllll}2 & \mathrm{C} & & -0.000000 & 2.009919 & -1.796318\end{array}$

$\begin{array}{llllll}3 & \mathrm{C} & & -0.000000 & 1.929485 & -0.377033\end{array}$

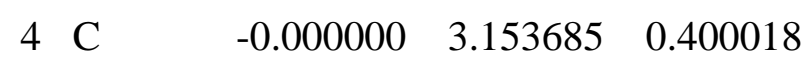

$\begin{array}{llllll}5 & \mathrm{C} & & -0.000000 & 4.388524 & -0.303907\end{array}$

$\begin{array}{llllll}6 & \mathrm{C} & & -0.000000 & 4.425271 & -1.670179\end{array}$

$\begin{array}{lllll}7 & \mathrm{H} & -0.000000 & 3.273598 & -3.504788\end{array}$

$\begin{array}{llllll}8 & \mathrm{H} & -0.000000 & 1.095387 & -2.373184\end{array}$

$\begin{array}{llllll}9 & \mathrm{C} & & -0.000000 & 3.115760 & 1.808397\end{array}$

$10 \mathrm{H} \quad-0.000000 \quad 5.308695 \quad 0.267614$

$11 \mathrm{H} \quad-0.000000 \quad 5.375984-2.187075$

$12 \mathrm{C} \quad-0.000000 \quad 1.918761 \quad 2.525010$

$13 \mathrm{H} \quad-0.000000 \quad 4.057922 \quad 2.342167$

$\begin{array}{llll}14 \mathrm{H} & 0.000000 & 1.917577 & 3.606558\end{array}$

$15 \mathrm{C} \quad-0.000000 \quad-1.918761 \quad 2.525010$

16 C $\quad-0.000000 \quad-3.115760 \quad 1.808397$

$17 \mathrm{C} \quad-0.000000 \quad-3.153685 \quad 0.400018$

$18 \mathrm{C} \quad-0.000000-1.929485 \quad-0.377033$ 


$\begin{array}{llll}19 \mathrm{C} & 0.000000 & -0.759558 & 1.773117 \\ 20 \mathrm{H} & -0.000000 & -5.308695 & 0.267614 \\ 21 \mathrm{H} & -0.000000 & -1.917577 & 3.606558 \\ 22 \mathrm{H} & -0.000000 & -4.057922 & 2.342167 \\ 23 \mathrm{C} & -0.000000 & -4.388524 & -0.303907 \\ 24 \mathrm{C} & -0.000000 & -2.009919 & -1.796318 \\ 25 \mathrm{C} & -0.000000 & -3.222884 & -2.423718 \\ 26 \mathrm{C} & -0.000000 & -4.425271 & -1.670179 \\ 27 \mathrm{H} & -0.000000 & -1.095387 & -2.373184 \\ 28 \mathrm{H} & -0.000000 & -3.273598 & -3.504788 \\ 29 \mathrm{H} & -0.000000 & -5.375984 & -2.187075 \\ 30 \mathrm{C} & 0.000000 & -0.760371 & 0.372731 \\ 31 \mathrm{C} & 0.000000 & 0.759558 & 1.773117 \\ 32 \mathrm{C} & 0.000000 & 0.760371 & 0.372731\end{array}$

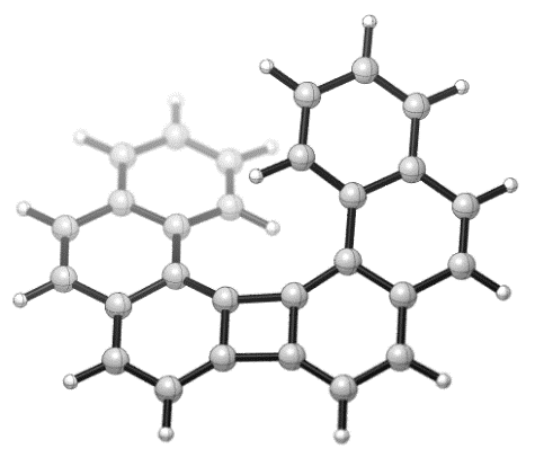

proximal-12a
$\begin{array}{llllll}1 & \mathrm{C} & & -3.528542 & -2.695302 & 0.475855\end{array}$

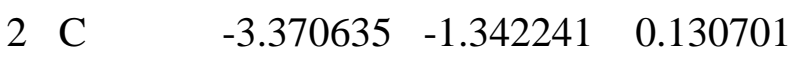
$\begin{array}{lllll}3 & \mathrm{C} & -2.117273 & -0.712938 & 0.347131\end{array}$

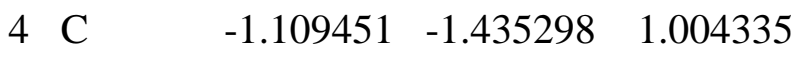

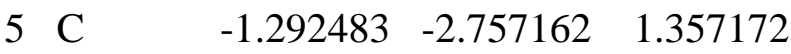

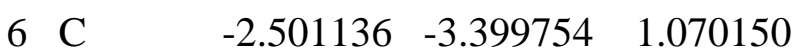
$\begin{array}{llllll}7 & \mathrm{C} & & -1.949042 & 0.677089 & -0.029590\end{array}$ 


\begin{tabular}{|c|c|c|c|}
\hline $8 \mathrm{C}$ & -0.760246 & 1.390515 & -0.051906 \\
\hline $9 \mathrm{H}$ & -4.483021 & -3.172670 & 0.290724 \\
\hline $10 \mathrm{H}$ & -2.639343 & -4.439186 & 1.338095 \\
\hline $11 \mathrm{C}$ & -4.473990 & -0.568565 & -0.363486 \\
\hline $12 \mathrm{C}$ & -4.365844 & 0.767272 & -0.549663 \\
\hline $13 \mathrm{C}$ & -3.122382 & 1.456040 & -0.362106 \\
\hline $14 \mathrm{H}$ & -5.226995 & 1.348862 & -0.855163 \\
\hline $15 \mathrm{C}$ & -3.055823 & 2.846052 & -0.513732 \\
\hline $16 \mathrm{C}$ & -1.864083 & 3.562156 & -0.344089 \\
\hline $17 \mathrm{C}$ & -0.742098 & 2.804149 & -0.113698 \\
\hline $18 \mathrm{H}$ & -1.844548 & 4.641206 & -0.412893 \\
\hline $19 \mathrm{C}$ & 3.528542 & -2.695302 & -0.475855 \\
\hline $20 \mathrm{C}$ & 3.370635 & -1.342241 & -0.130701 \\
\hline $21 \mathrm{C}$ & 2.117273 & -0.712938 & -0.347131 \\
\hline $22 \mathrm{C}$ & 1.109451 & -1.435298 & -1.004335 \\
\hline $23 \mathrm{C}$ & 1.292483 & -2.757162 & -1.357172 \\
\hline $24 \mathrm{C}$ & 2.501136 & -3.399754 & -1.070150 \\
\hline $25 \mathrm{C}$ & 1.949042 & 0.677089 & 0.029590 \\
\hline $26 \mathrm{C}$ & 0.760246 & 1.390515 & 0.051906 \\
\hline $27 \mathrm{H}$ & 4.483021 & -3.172670 & -0.290724 \\
\hline $28 \mathrm{H}$ & 2.639343 & -4.439186 & -1.338095 \\
\hline $29 \mathrm{C}$ & 4.473990 & -0.568565 & 0.363486 \\
\hline $30 \mathrm{C}$ & 4.365844 & 0.767272 & 0.549663 \\
\hline $31 \mathrm{C}$ & 3.122382 & 1.456040 & 0.362106 \\
\hline $32 \mathrm{H}$ & 5.226995 & 1.348862 & 0.855163 \\
\hline $33 \mathrm{C}$ & 3.055823 & 2.846052 & 0.513732 \\
\hline $34 \mathrm{C}$ & 1.864083 & 3.562156 & 0.344089 \\
\hline $35 \mathrm{C}$ & 0.742098 & 2.804149 & 0.113698 \\
\hline $36 \mathrm{H}$ & 1.844548 & 4.641206 & 0.412893 \\
\hline $37 \mathrm{H}$ & 5.419187 & -1.070946 & 0.527850 \\
\hline $38 \mathrm{H}$ & 3.968350 & 3.376380 & 0.755602 \\
\hline $39 \mathrm{H}$ & -3.968350 & 3.376380 & -0.755602 \\
\hline
\end{tabular}




$\begin{array}{llllr}40 \mathrm{H} & & -5.419187 & -1.070946 & -0.527850 \\ 41 \mathrm{H} & 0.497433 & -3.294224 & -1.857232 \\ 42 \mathrm{H} & 0.183568 & -0.941496 & -1.256747 \\ 43 \mathrm{H} & -0.497433 & -3.294224 & 1.857232 \\ 44 \mathrm{H} & -0.183568 & -0.941496 & 1.256747\end{array}$

